Fall 1929

\title{
1929 Cedrus Yearbook
}

\section{Cedarville College}

Follow this and additional works at: https://digitalcommons.cedarville.edu/yearbooks

Part of the Higher Education Commons, Organizational Communication Commons, and the Public Relations and Advertising Commons

\section{Recommended Citation}

Cedarville College, "1929 Cedrus Yearbook" (1929). Yearbooks. 80.

https://digitalcommons.cedarville.edu/yearbooks/80

This Book is brought to you for free and open access by DigitalCommons@Cedarville, a service of the Centennial Library. It has been accepted for inclusion in Yearbooks by an authorized administrator of DigitalCommons@Cedarville. For more information, please contact digitalcommons@cedarville.edu. 


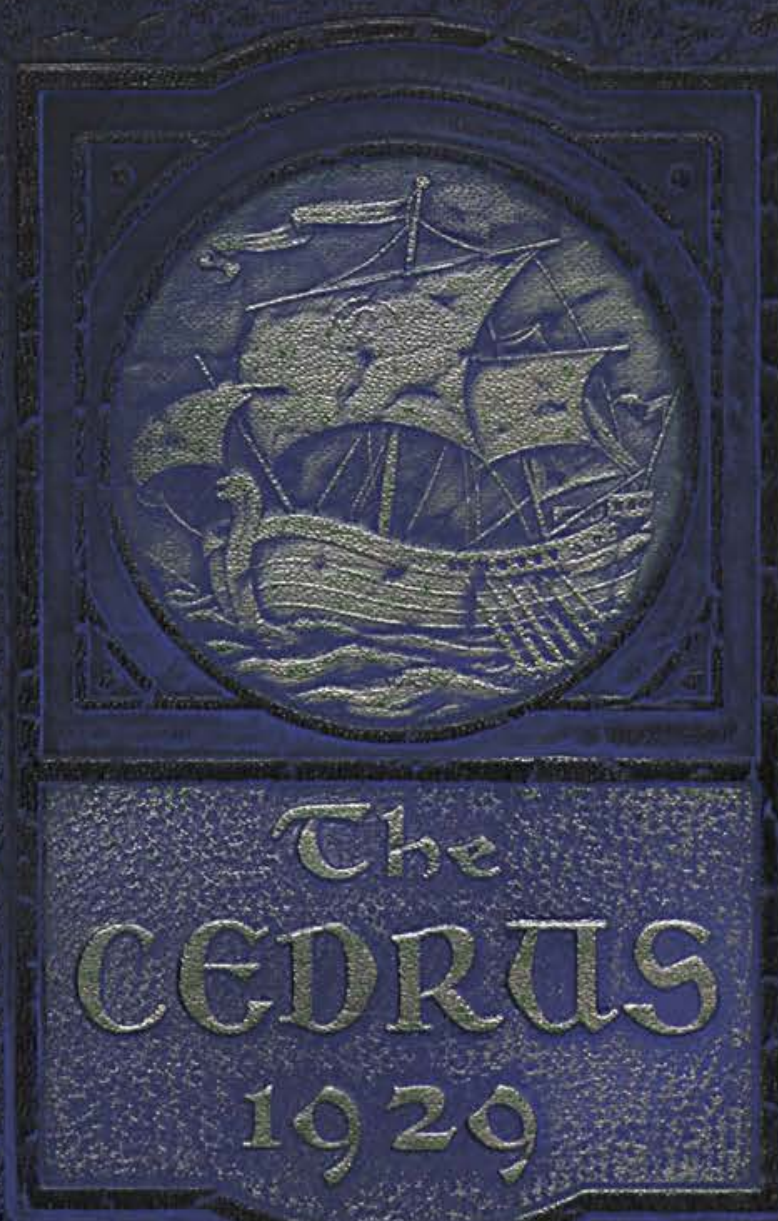

(1)

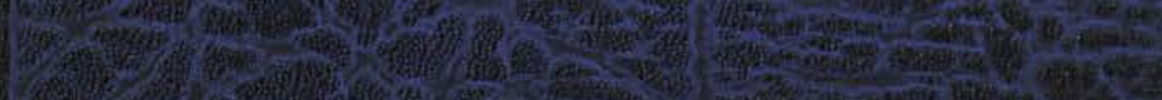

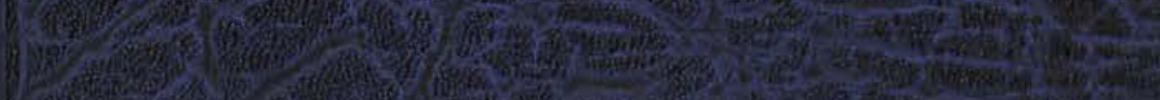

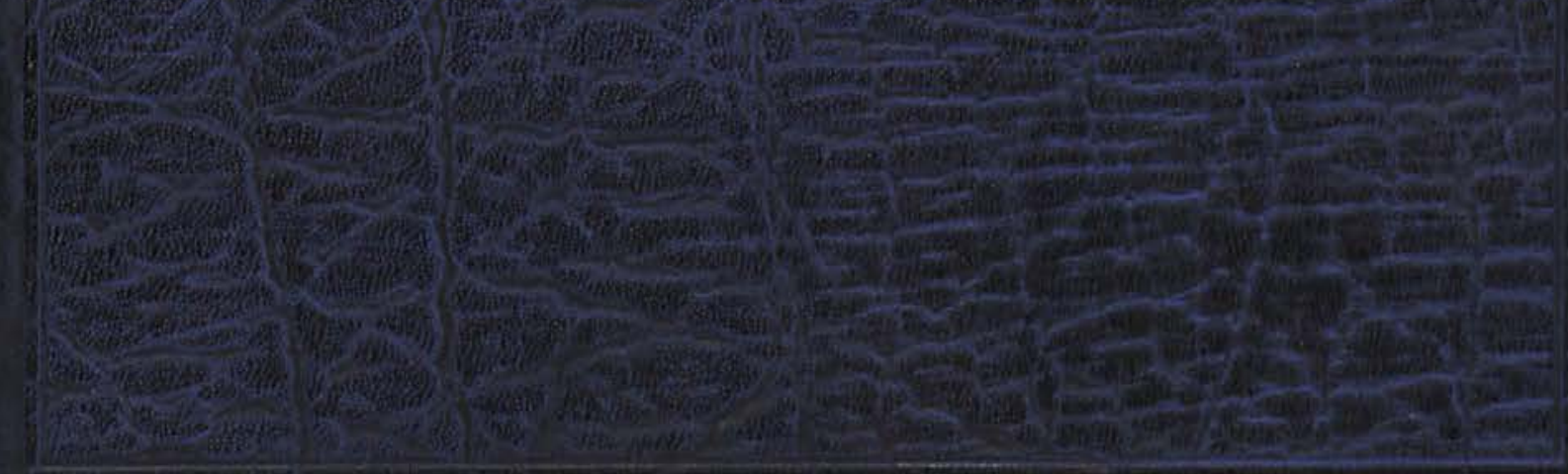




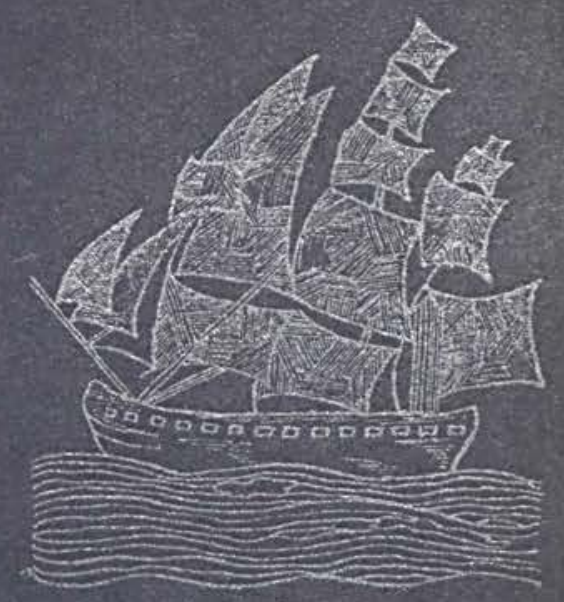

Ex Libris 


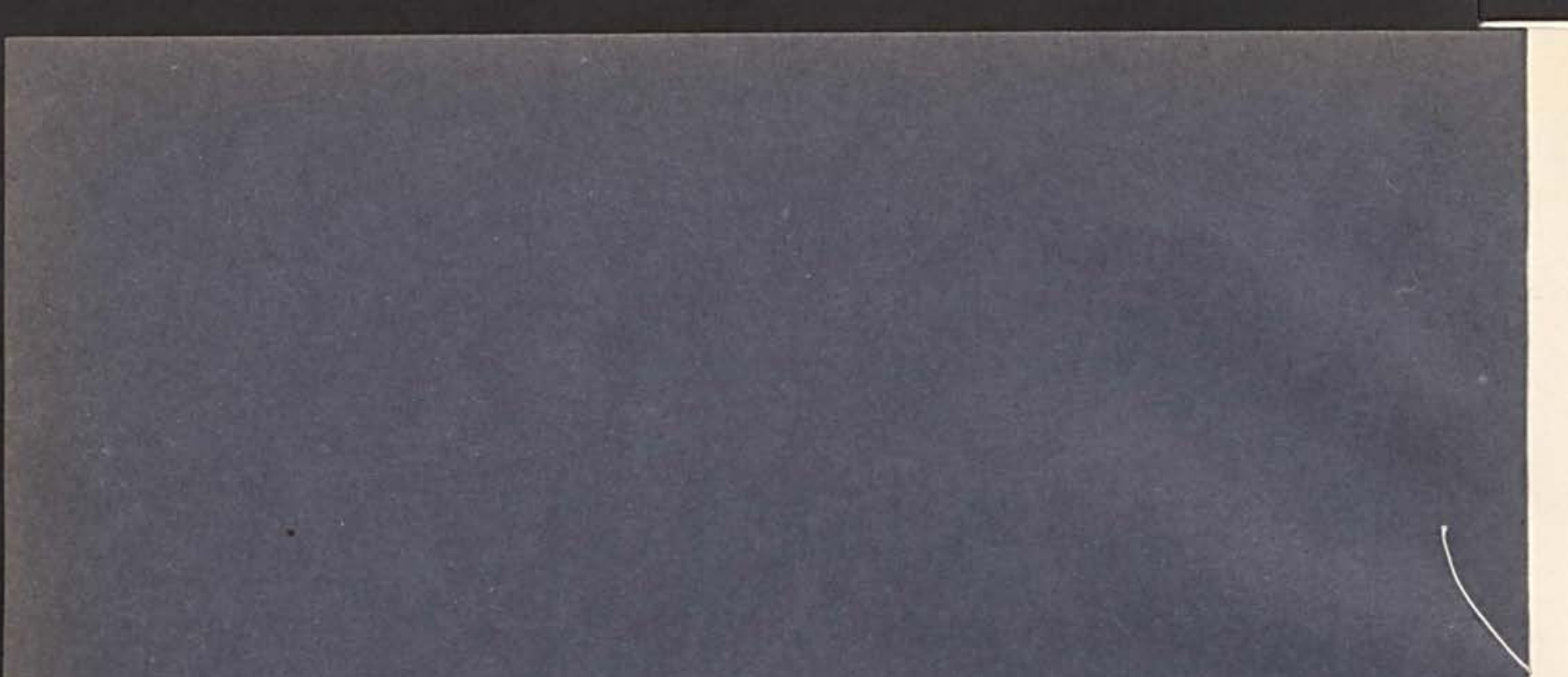




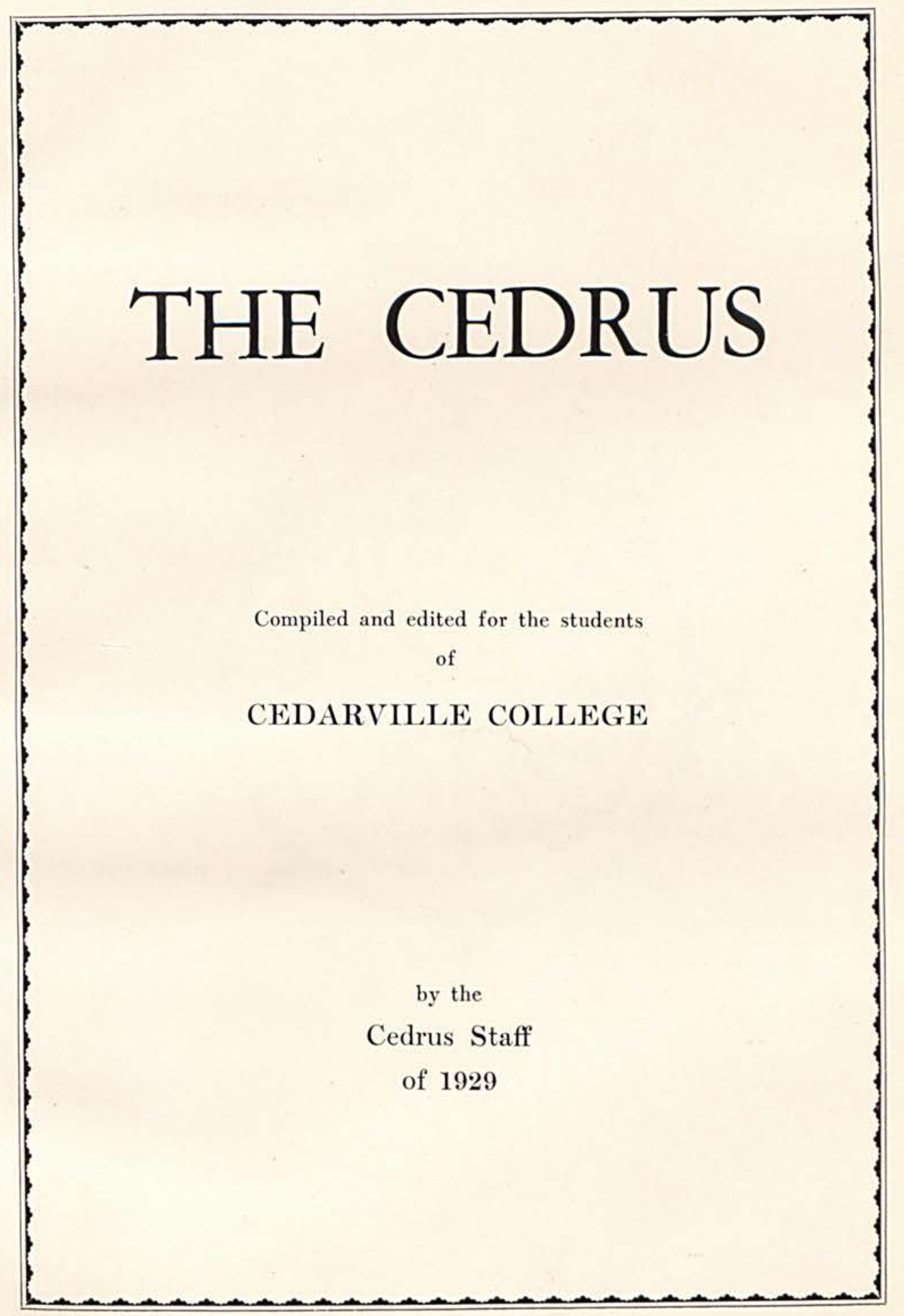




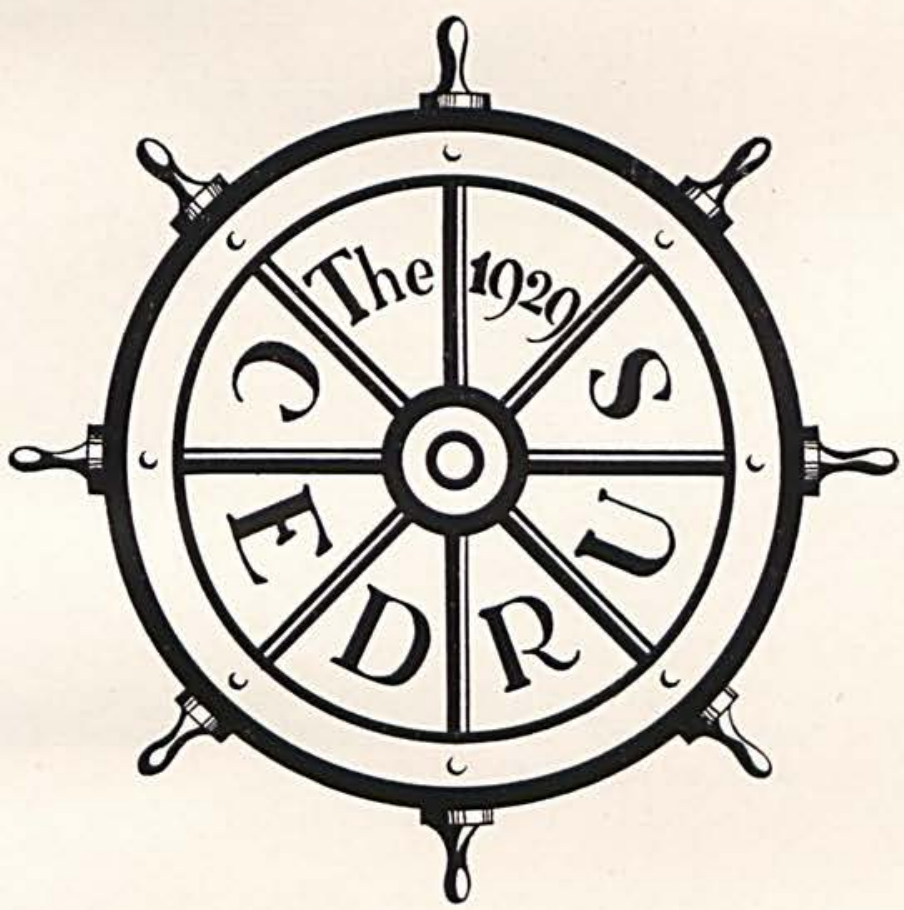




\title{
Foreword
}

\begin{abstract}
A the time swiftly approaches when we again shall depart from the halls of our beloved Alma Mater-some of us for only a few short months, and some of us forever as students of Cedarville College-it is well that we should prepare to take with us some record of the activities of the year. Thus, in the dim and distant future, when many a grain of sand has trickled through the glass of time, and the now vivid memories of the successes and failures, the joys and sorrows of our college days have been somewhat erased by the daily cares and trials of life, we may take down this volume, dusty, tattered, and torn, and live again those happy days spent at dear old C. C.
\end{abstract}




\section{The Cedrus}

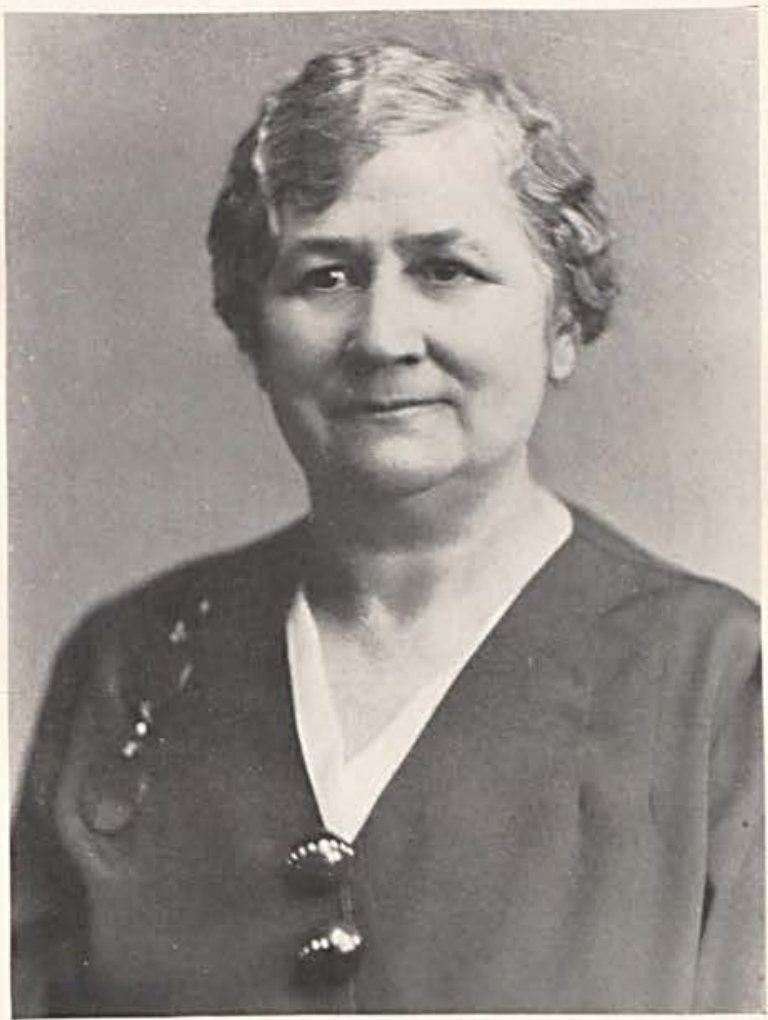

\section{Dedication}

To Mrs. Clara Morton, who during the past nine years has so humbly and efficiently served the College Club, and who during that time has so kindly been both friend and mother to the boys and girls with whom she has come in contact, do we dedicate The Cedrus of 1929. 


\section{The Cedrus}

\section{Order of Book}

I. VIEWS

II. FACULTY

III. SENIORS

IV. JUNIORS

V. SOPHOMORES

VI. FRESHMEN

VII. ATHLETICS

VIII. ORGANIZATIONS

IX. ACTIVITIES

X. HUMOR 


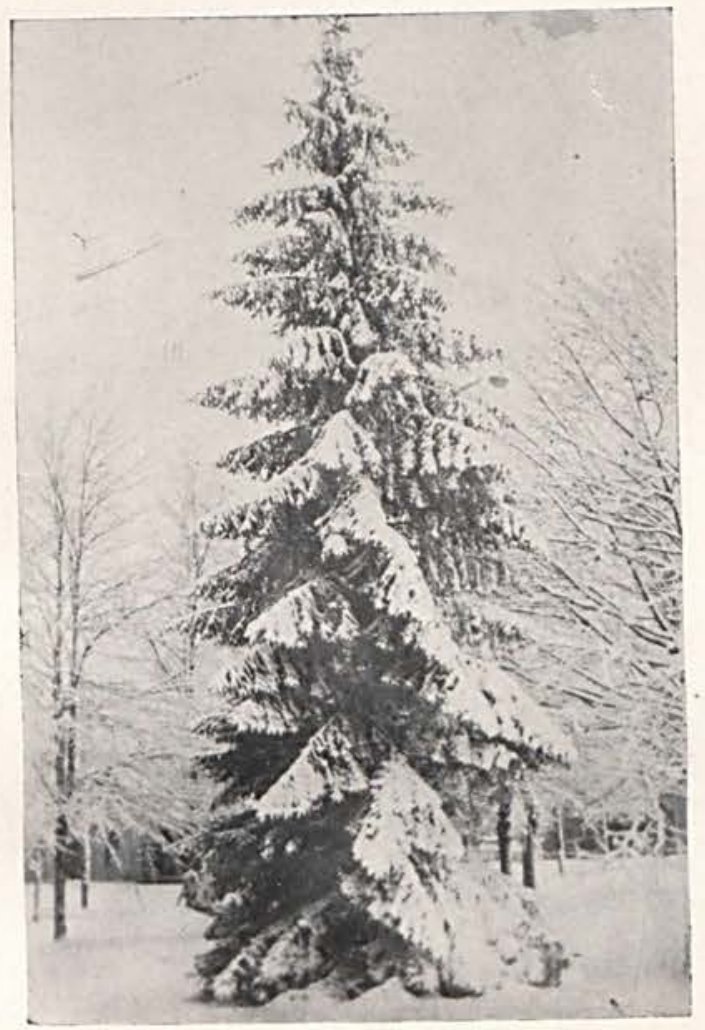

Views 

The Cedrus
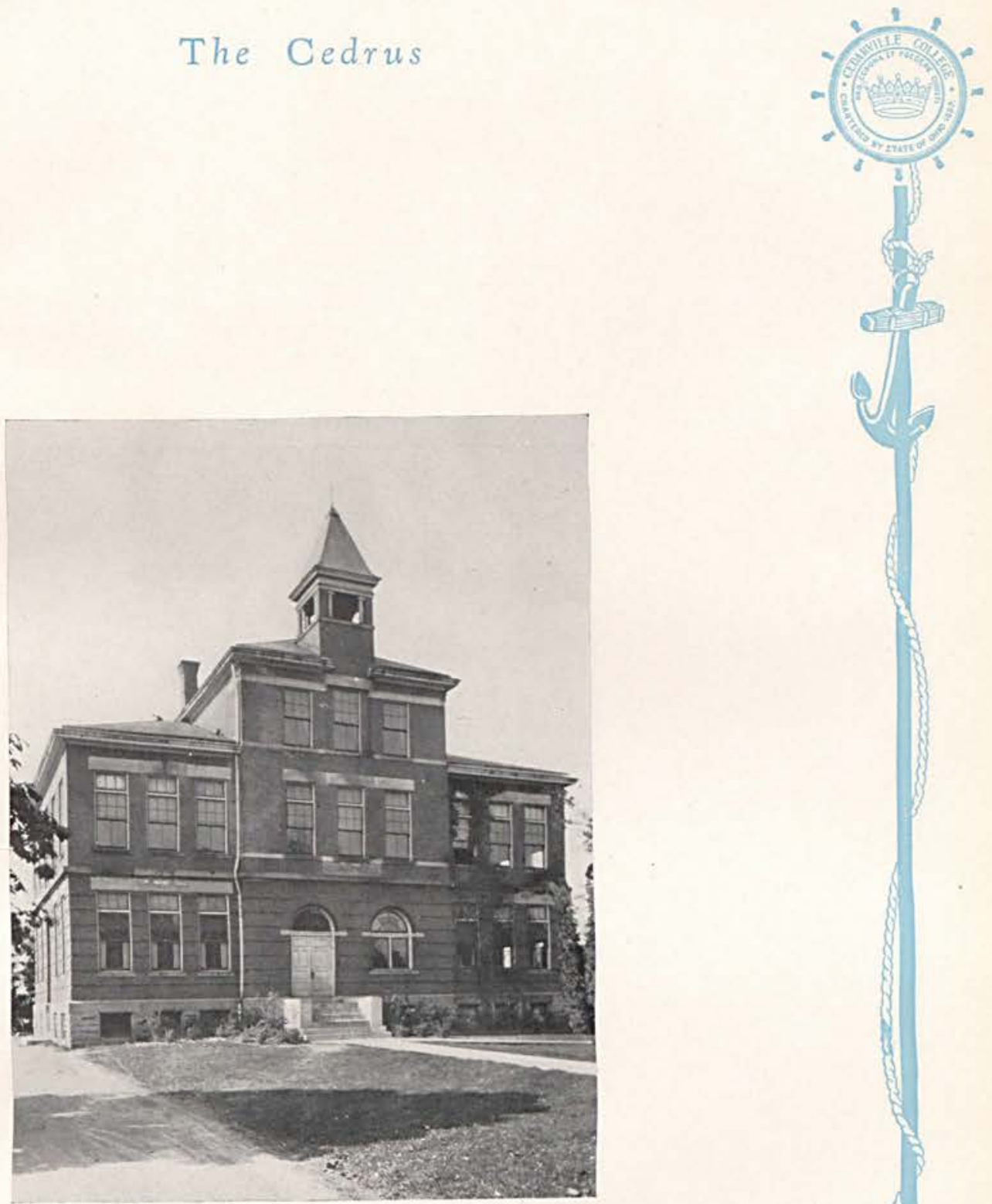

Old Main

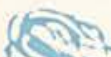




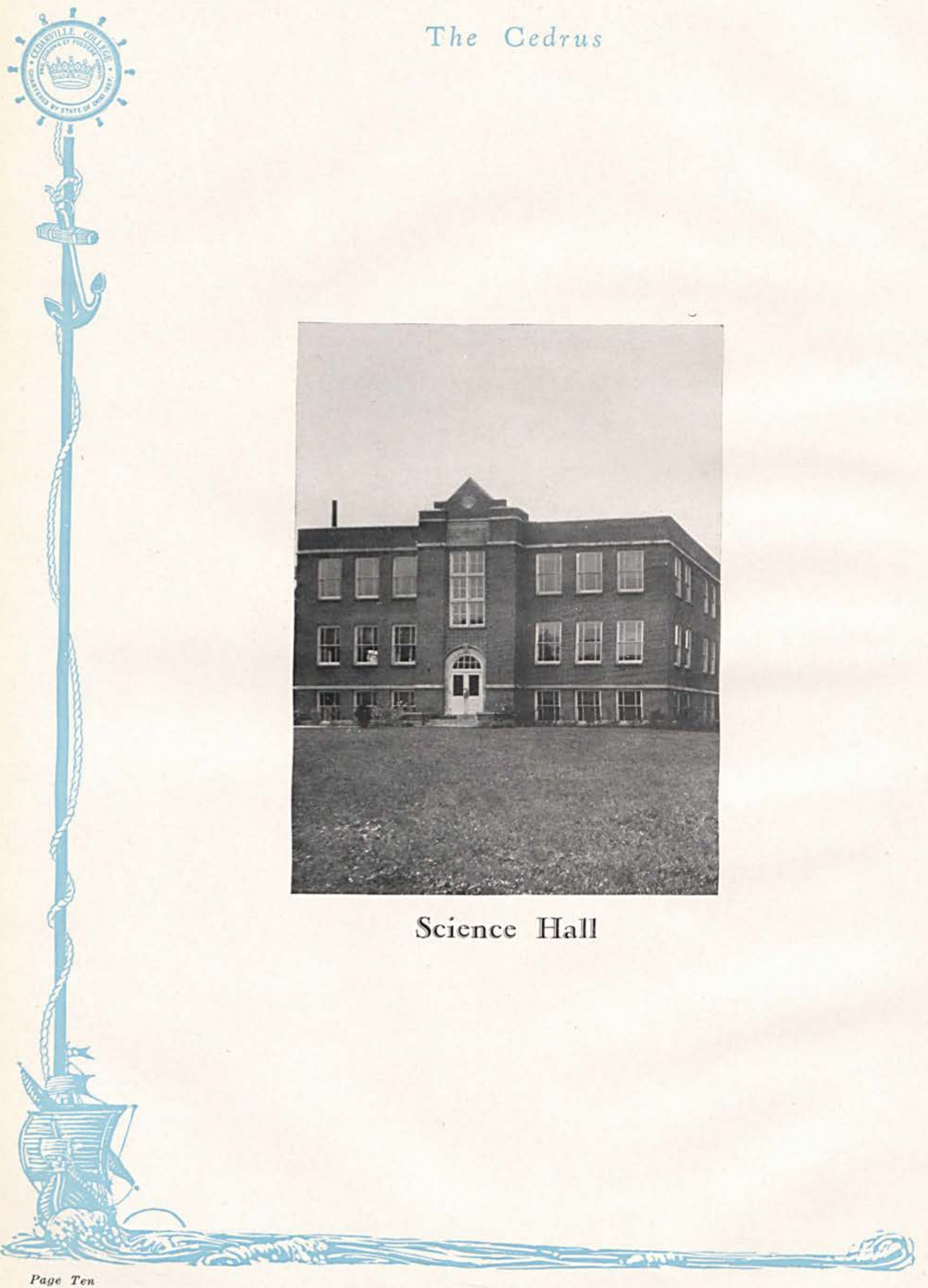


The Cedrus
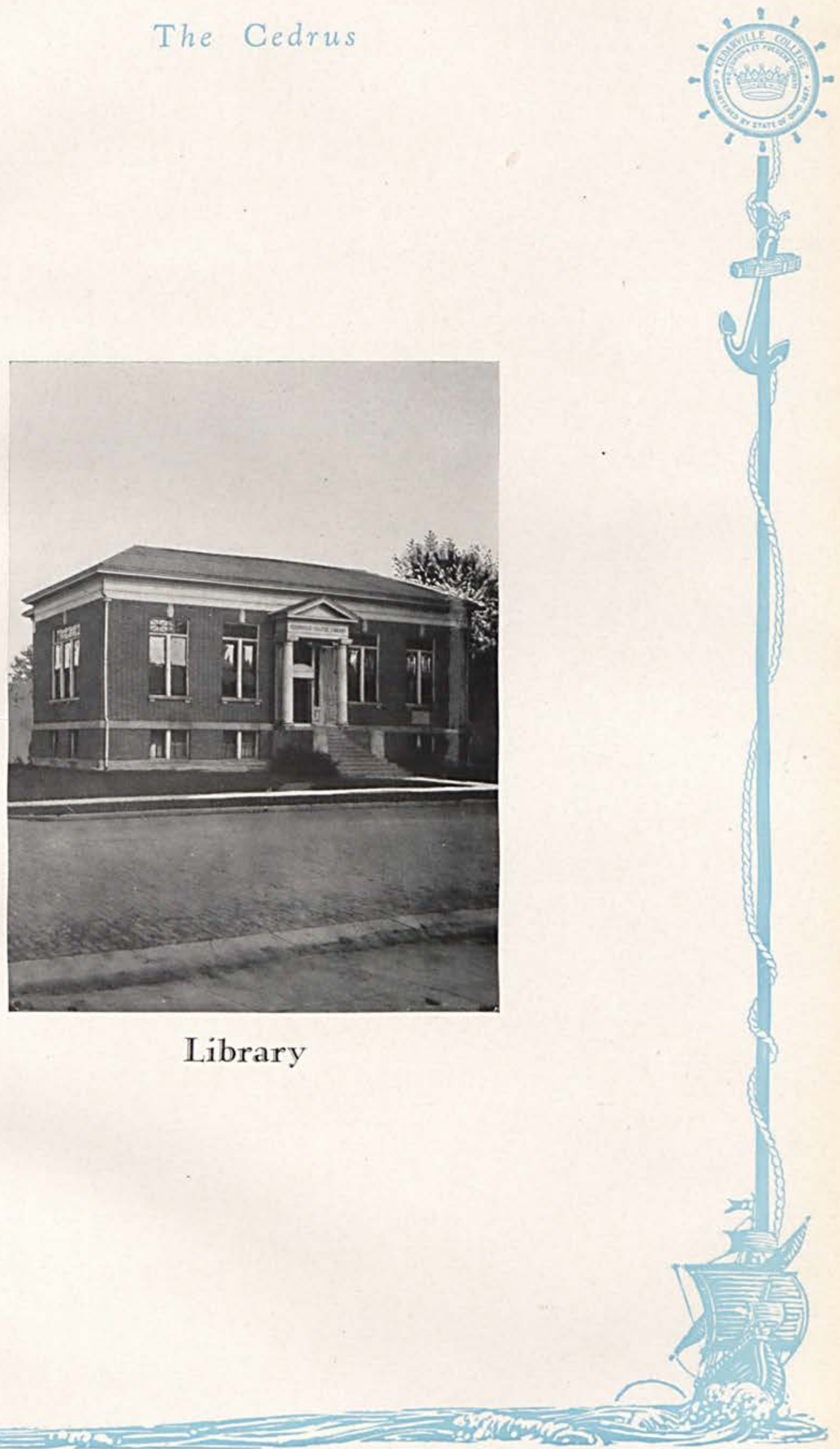

Library 
The Cedrus

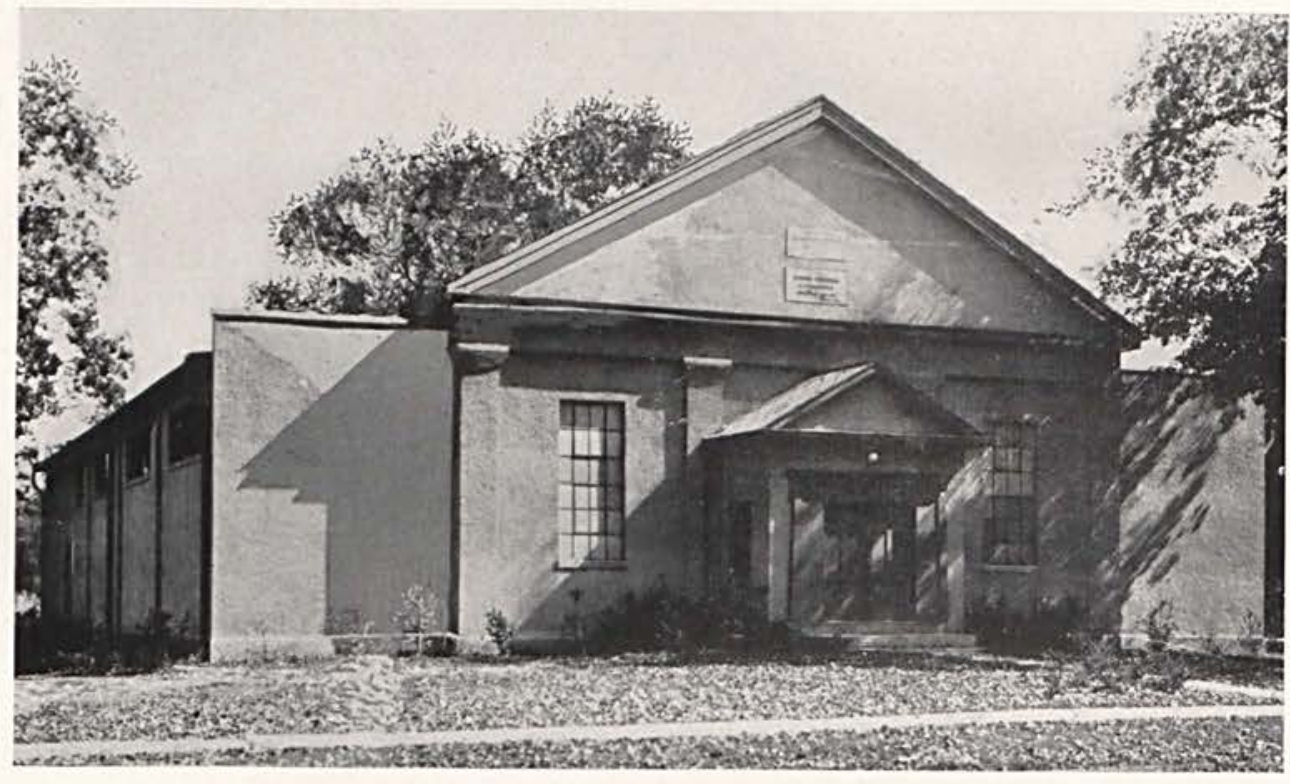

Alford Memoriai Gymnasium 

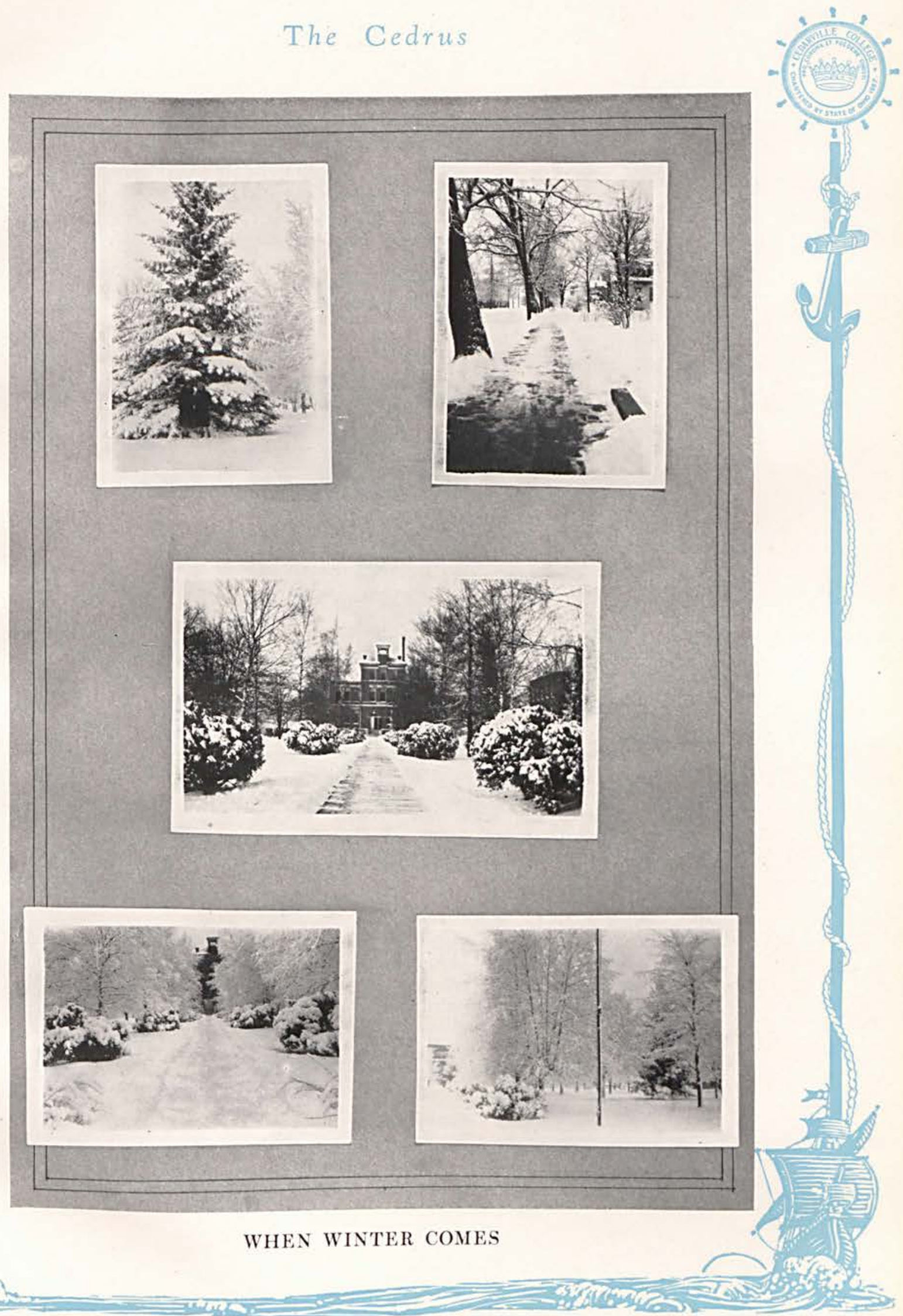

WHEN WINTER COMES 


\section{The Cedrus}

\section{"Because-"}

Because you've held the laughter and the songs

$$
\text { Of many; }
$$

Because you've shared the joys, nor shunned the wrongs

$$
\text { Of any; }
$$

Because you've kept their faith and yours till

The youth of them had drunk your wisdom's fill,-God bless you-

\section{Cedarville!}

Because we'll love you and your memories Forever ;

Because you merit all our love for Love's Endeavor;

Because you hold the note of Love's own trill

For those who come beneath your beck and will;-

God love you-

$$
\text { Cedarville! }
$$

Because you cherish those who came before,

$$
\text { Inciting; }
$$

Because you stretch out eager arms to more,

$$
\text { Inviting; - }
$$

To those who want a turn at this-your mill,-

To those who now are learning-always will:-

God guard you-

$$
\text { Cedarville! }
$$

Because of all you've meant and all you'll mean Hereafter;

Because of all you're built of; - -hopes, and tears, And laughter,

And prayers, and ideals, and regrets,

And even lives, - and now encouragements;-

God keep you-

\section{Cedarville!}




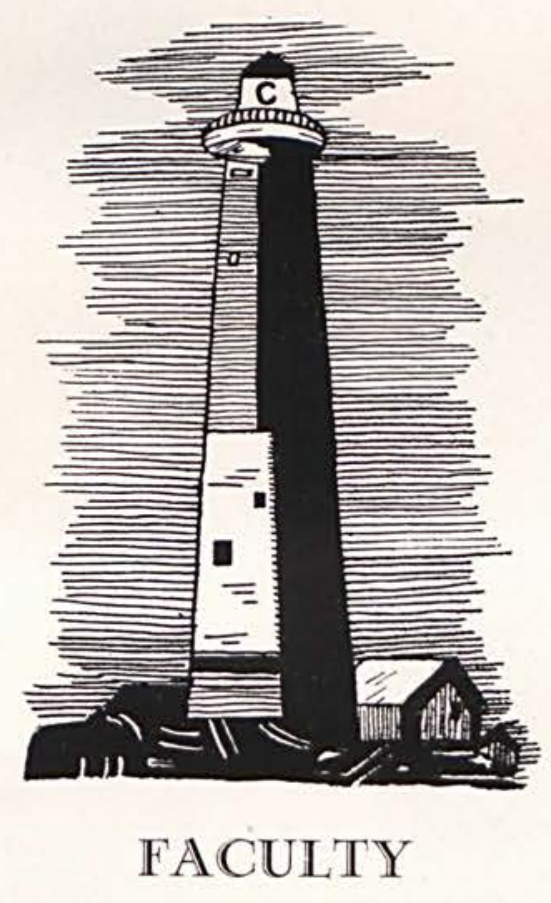





\section{The Cedrus}

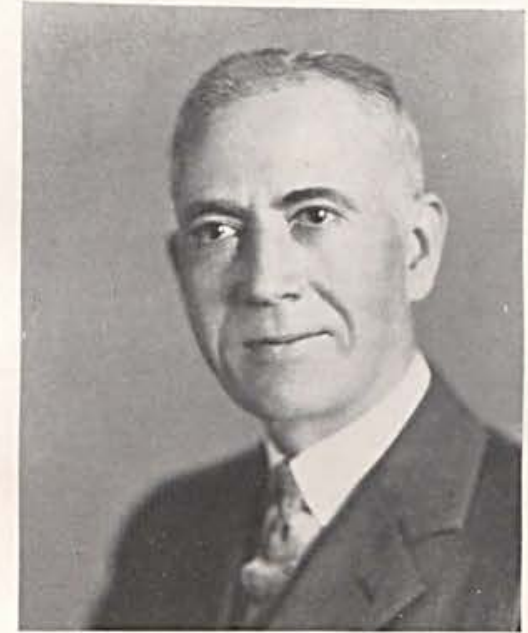

FRANK ALBERT JURKAT Treasurer

Professer of Languages and History

A. B. Franklin College 1895

A. M. Franklin College 1898

LL. D. Franklin College 1917

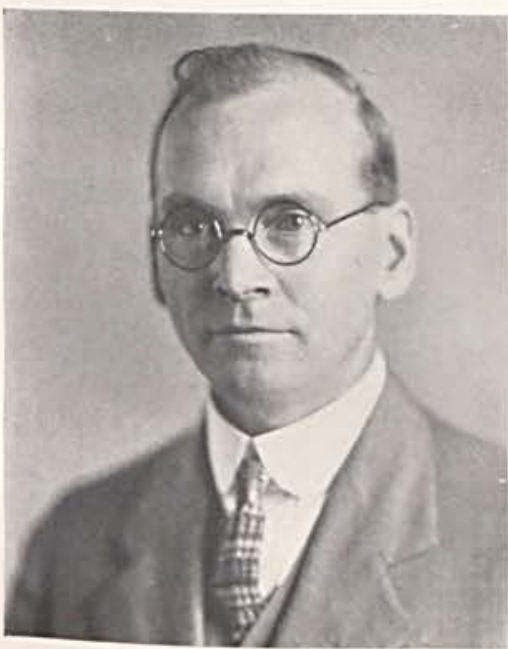

\section{WIIBER'T RENWICK McCHESNEY}

President

Peter Gibson Professor of Philosophy and Greek

A. B. Franklin College 1892

A. M. Franklin College 1894

$\mathrm{Ph}$. D. Franklin College 1906

D. D. Tarkio College 1915

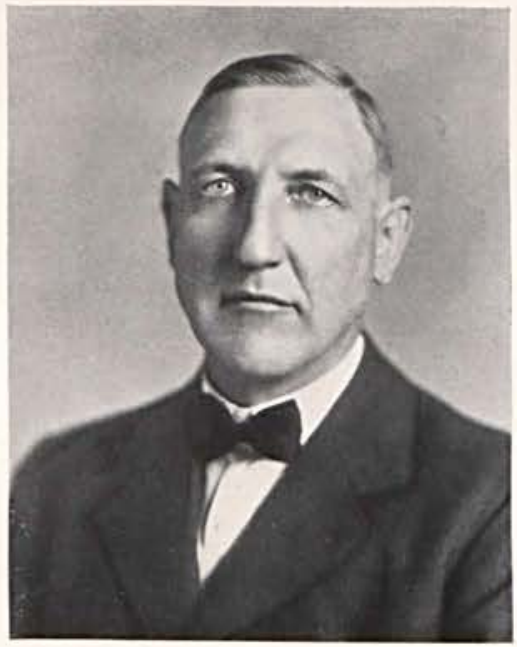

Head Department of Education

B. S. Ohio Northern University 1908

\section{ALVIN JEROME HOSTETLER}
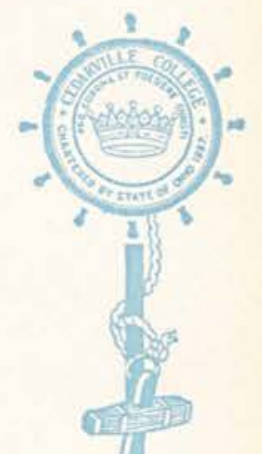

iv
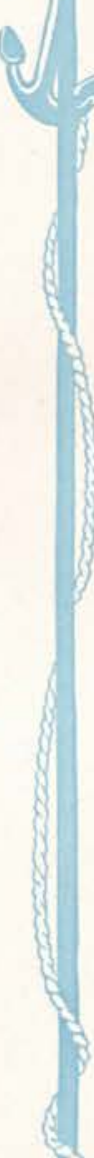


\section{The Cedrus}
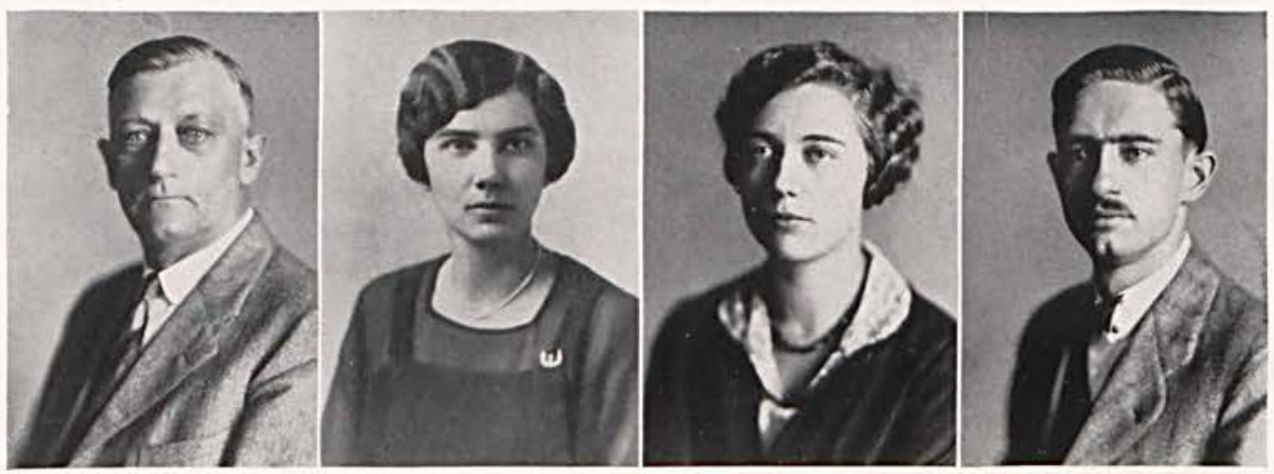

C. W. STEELE

RU'TH L. BROWN

Professor of Social Sciences

A. B. Indiana State Normal School 1927

Professor of Mathematics and English

A. B. Oberlin College 1927

A. M. Oberlin College 1928

YULA PARAN LIEVING

Secretary to the Fresident

Registrar and Acting Dean

Professor of French

A. B. Marietta College 1925

Phi Beta Kappa

\section{OTTO W. KUEHRMANN \\ Professor of Science}

B. S. Purdue University 1925

Butler University 


\section{The Cedrus}
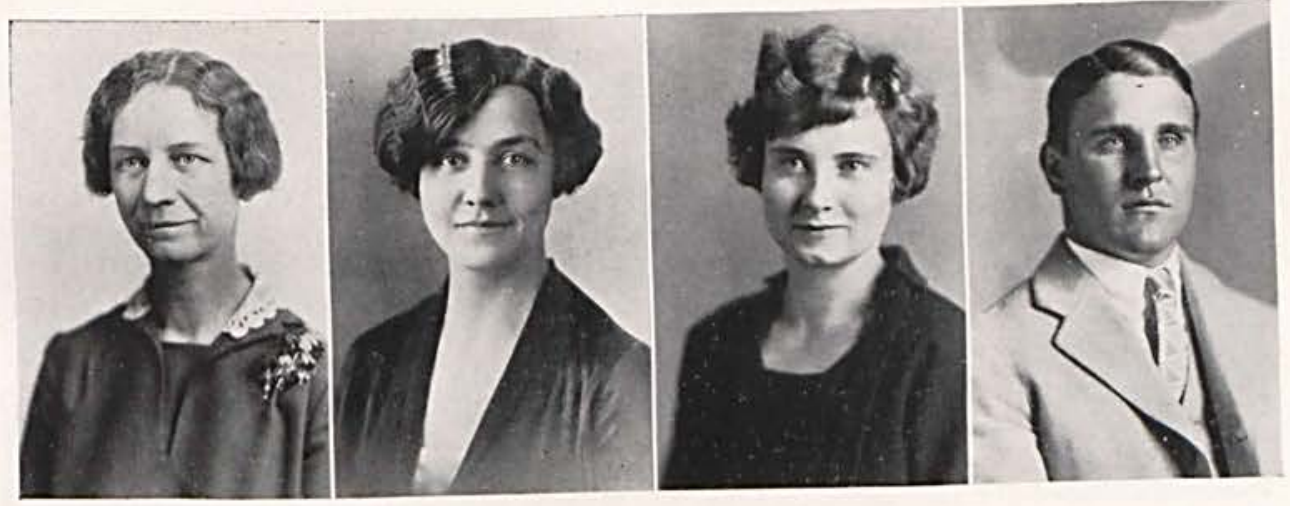

MARY ABIGALI, BRISTOW

Director of Teacher Training

A. B. Wittenberg College 1920

A. M. Columbia University 1926

\section{RUTH ANN BURNS}

Instructor in Public School Music

A. B. Cedarville College 1928

Graduate in Voice

Cedarville College 1921

\section{VIRGINIA PARRY}

Dean of Women

Professor of Education

A. B. Ohio State University 1921

A. M. Ohio State University 1923
ROY MARVIN BORST

Director of Physical Education

Professor of Spanish

B. S. Wittenberg College 1926

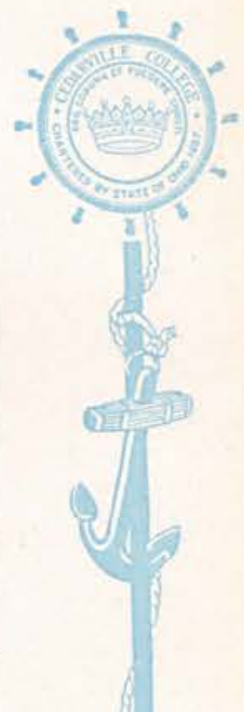



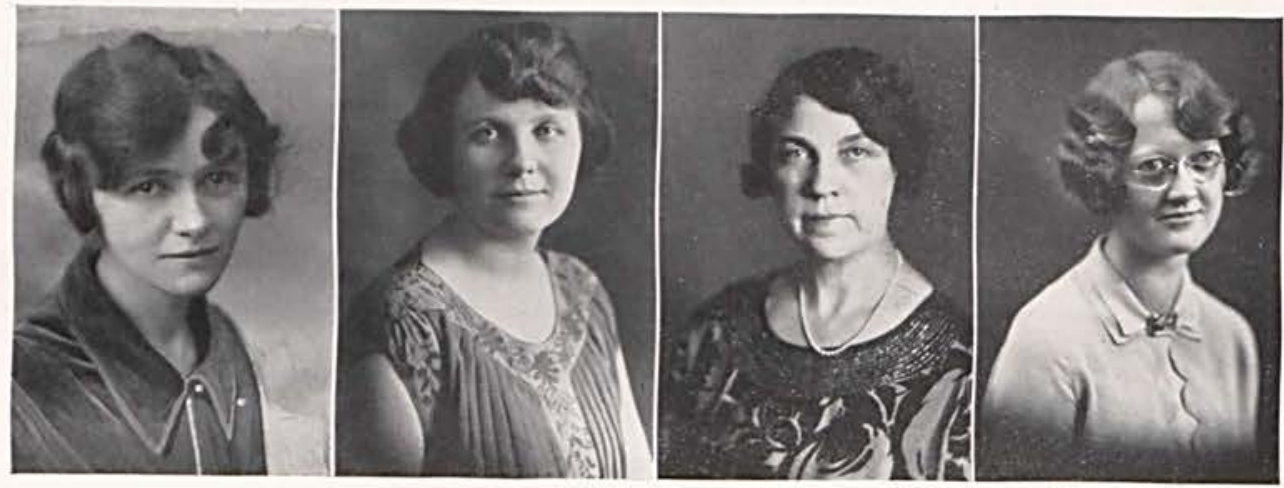

\section{MRS. HELEN LAUGHLIN CORRY}

Assistant in Department of Music

Wooster College Conservatory of Music 1913

JENNIE MILDRED LUST

Instructor for Elementary Teachers

Ohio Northern University

Ohio University

Ohio State University

\section{LYDIA A. BERKLEY}

Director of Music

M. M. Lincoln Conservatory of Music B. M. Hiram College

\section{MARTHA HELEN DEAN \\ Professor of Latin and Bible Assistant in Office}

A. B. Cedarville College 1927

Summa Cum Laude

Graduate in Piano, Cedarville College,

CHARLES M. RICHIE

Professor of Homiletics and Com-

parative Religions

$\mathrm{Ph}$. D. Grove City College 1910

D. D. Cedarville College 1916 


\section{THE FACULTY}

$\mathrm{T}$

HE Cedrus Staff considers it a privilege and an honor to place the name of Dr. McChesney at the head of the Faculty. Dr. McChesney, who has been a member of the Faculty for thirty-five years and President for fourteen years, besides rendering numerous services to the community and country at large, still finds time to teach Philosophy, Greek, Psychology, Logic, and Oratory.

Dr. Jurkat, who became a member of the Faculty in 1897 , besides teaching History and Languages, serves in the capacity of Treasurer of the college, and helps the Freshmen take their first steps toward securing their college degrees.

Miss Leiving, since 1925, has been Registrar, Secretary to the President, and Professor of French. It is to her reliable statistics that the students must refer their puzzling questions concerning credits and requirements.

Under the supervision of Professor Borst, Director of Physical Education, the athletic teams representing Cedarville College have become better and more widely known. Also, Professor Borst has charge of the teaching of Spanish.

Professor Hostetler, head of the Department of Education, has proved to be a most capable instructor of those subjects which tend to train students for more efficient teaching.

This is the second year that Miss Bristow has been a member of the Department of Education. This year, as Director of Teacher Training, she managed the difficult task of providing a proper observation and student teaching program for prospective teachers.

Miss Dean, one of Cedarville College's own danghters, has been a most conscientious Professor of Latin and Bible during the past two years. Not only those in her classes, but the entire student body will miss her sunny smile when she leaves Cedarville.

Miss Lust, Instructor for Elementary Teachers, has maintained the reputation earned last year of being an inspiration to students and future teachers.

Miss Brown has not been with us long, but she is recognized as a competent Professor of Mathematics and English, and we expect several Cedrus Staffs of the future to include her name in the Faculty list.

Professor Steele came to us this year from Indiana, and in the capacity of Professor of Social Sciences and Public Speaking has won the approval and admiration of the entire student body.

Professor Kuehrmann, also from the Hoosier State, is rendering excellent service in the Science Department of the college. We hope his plans for a more complete Science Curricula may be realized.

Miss Parry, as Professor of Education, is a splendid example of efficiency. She is also Dean of Women.

Students enrolled in the Seminary are enthusiastic in their assertions concerning the way in which the Truth has been revealed by Reverend Ritchie in teaching Homiletics and Comparative Religions.

Miss Berkley is well qualified for the position of Director of Music, and is giving excellent service to the college. She is to be commended for her faithful support of student activities.

Mrs. Corry has been with the college since 1926. During the past two years she has given invaluable assistance in the Department of Music.

This is the second year that Miss Burns, a graduate of Cedarville College, has been Instructor of Public School Music. 


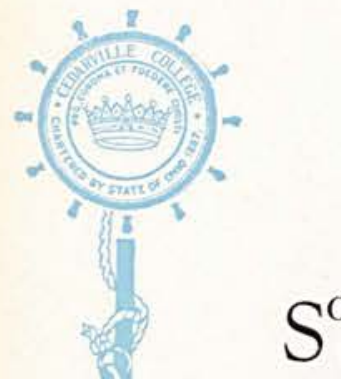

\section{Faculty Crusts}

SOME teachers are crusty old things-I know you will agree, but wait until I finish the statement-crusty on the outside. Recently I have been making some pseudo-scientific investigations, and I here report my findings.

One day I suddenly caught a gleam as of a jewel, in the vicinity of the heart, and having a pirate-like love for treasure-seeking, I began my search. I might explain that in my experiment, I chose to work upon the crust as near the heart as possible.

It is only by very careful microscopic investigation that we are able to analyze this crust. It seems to be a kind of professional air. In some places it is composed of ver: close, attack-resisting cells, almost impenetrable, while in other places it is of a more porous nature. We find upon closer examination that the crust is made up of a number of layers, in some places only two or three, although in other places as many as thirteen have been found. With continual work for fourteen weeks deducting only the minimum amount of time for rest and nourishment, I finally, yet ever so gently passed through the twelfth layer.

Let me give a warning. Don't ever try to use force or coldness to try to get through the crust, because it won't work. The best and surest method is to use warmth, and love, and sympathy. The crusts gradually melt before tools such as these. Well, what about the thirteenth crust? When I reached it I found it very, very hard yet warm and transparent. I realized it would be sacrilege to attempt to go farther. But my work had not been in vain. I had found a treasure! I could see it there in all its magnificence, under the thirteenth layer. It would be ruthless to expose it to the outside world, so I laid aside my tools and just sat and watched. The layers I had passed through began to cement themselves together again. Was I disappointed? No, my joy was boundless! I was satisfied. I knew what was down underneath. I had proved my guess. Don't get the mistaken notion that the treasure is entirely hidden. Its sublime beauty emanates from it through all the crusts. How wonderful it is then, close at hand.

Friends, this investigation was true. The conclusions reached are true. Underneath every outside crust there is something precious. If you don't believe it, experiment for yourself. Perhaps you don't think crusts are necessary; perhaps you think this professional air should be thrown away. Let me ask you something: Why does the kernel of a nut have an outer shell? Why are the earth's treasures often hidden so deeply? The same answer will apply. There is something infinitely precious, something sacred in the heart of a teacher, and it must be protected from knocks and injuries by thick coverings. Yet it's there just the same and it's worth the search. There's more in the heart of a teacher than most of us ever realized, but still we're thankful for crusts!

E. W. 


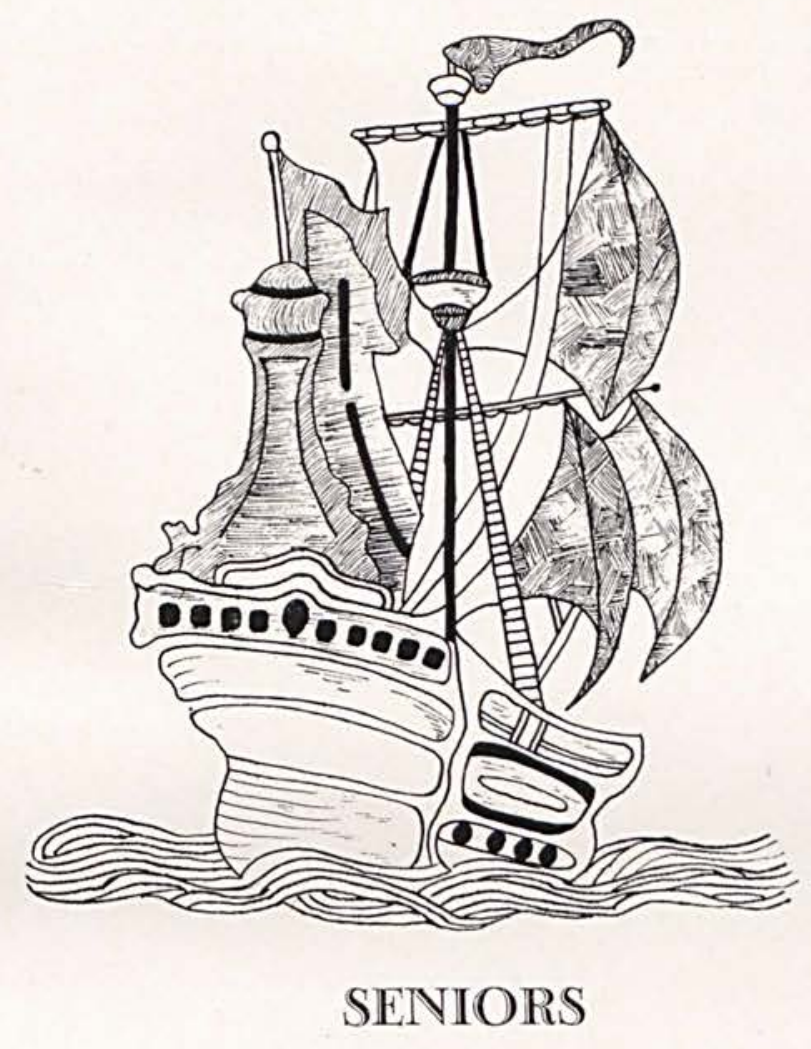





\section{The Cedrus}

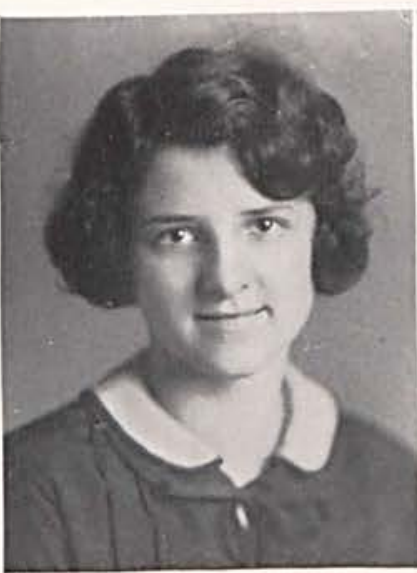

CHANDLER

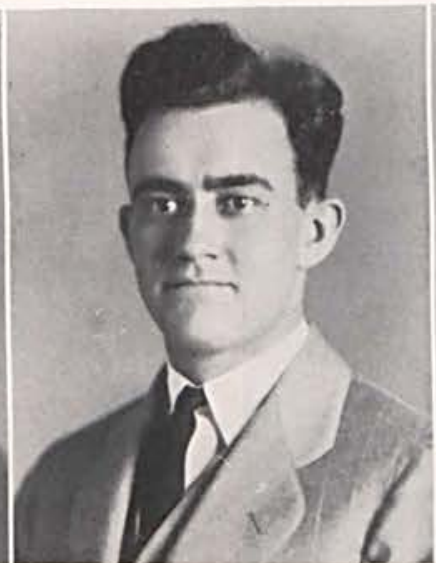

BEAM

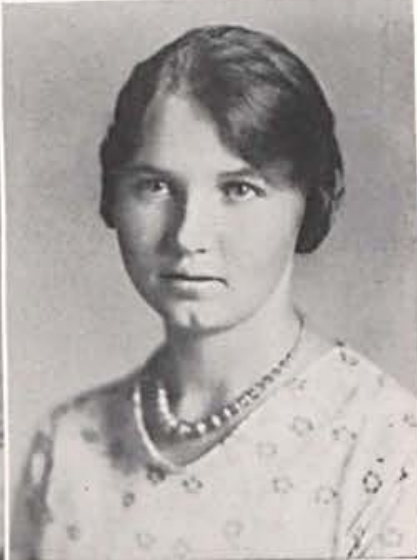

WIGAL

\section{Senior Class}

Margaret Chandler

President

James Beam

Vice-President

Edith Wigal

Secretary-Treasurer

What can a few sentences mean, what can a few phrases say, what can a few words express about the class of twenty-nine?

There are so many memories of the past year that crowd to our minds as we write the last will and testament of a group that has fought obstacles in order that its members may pass from Cedarville's halls with a degree. And now that we are just on the verge of being thrust into life's arms-are we glad? No, we have regrets and fears. Yet we know that the spirit of our Alma Mater leads us on to do our share of the world's work.

It amuses us to revert our thoughts to a September day in twenty-five when we entered college. Scraps, watermelon feeds, new acquaintances, and new friends are some of the assets of that Freshman year.

As Sophomores we found that our prestige had increased slightly and our heads had swelled exceedingly.

Then the name of Junior was fastened upon us. Yes, we felt it keenly, too, especially when our uppers called us "Twenty-nine Junior." Yet we grew and grew. We gave a play that some called "Clarence," We called it "A Lot of Work, Well Repaid." This event helped us to entertain Twenty-eight Seniors to a banquet in Dayton.

Just a few days ago, it seems, we passed through the September sunshine and heard the Freshies whisper "Senior," Today we are being measured for our caps and gowns. Tomorrow we will have a scroll of very white paper tied in college colors. Now, for a time, we must say goodbye to dear friends. We are outside of the gates of college life, but our pleasant thoughts and wishes still linger to join a throng of similar phantoms like ourselves that haunt the halls and campus of Cedarville College.

M. A. C.
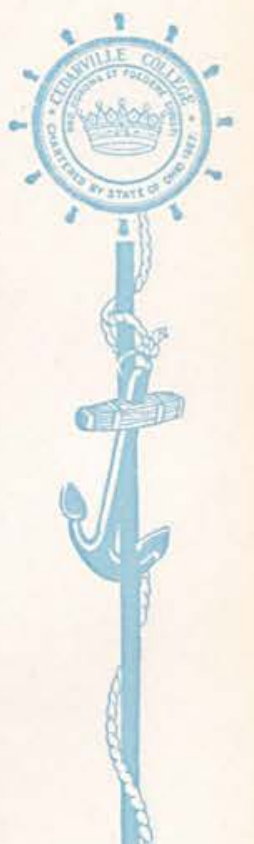


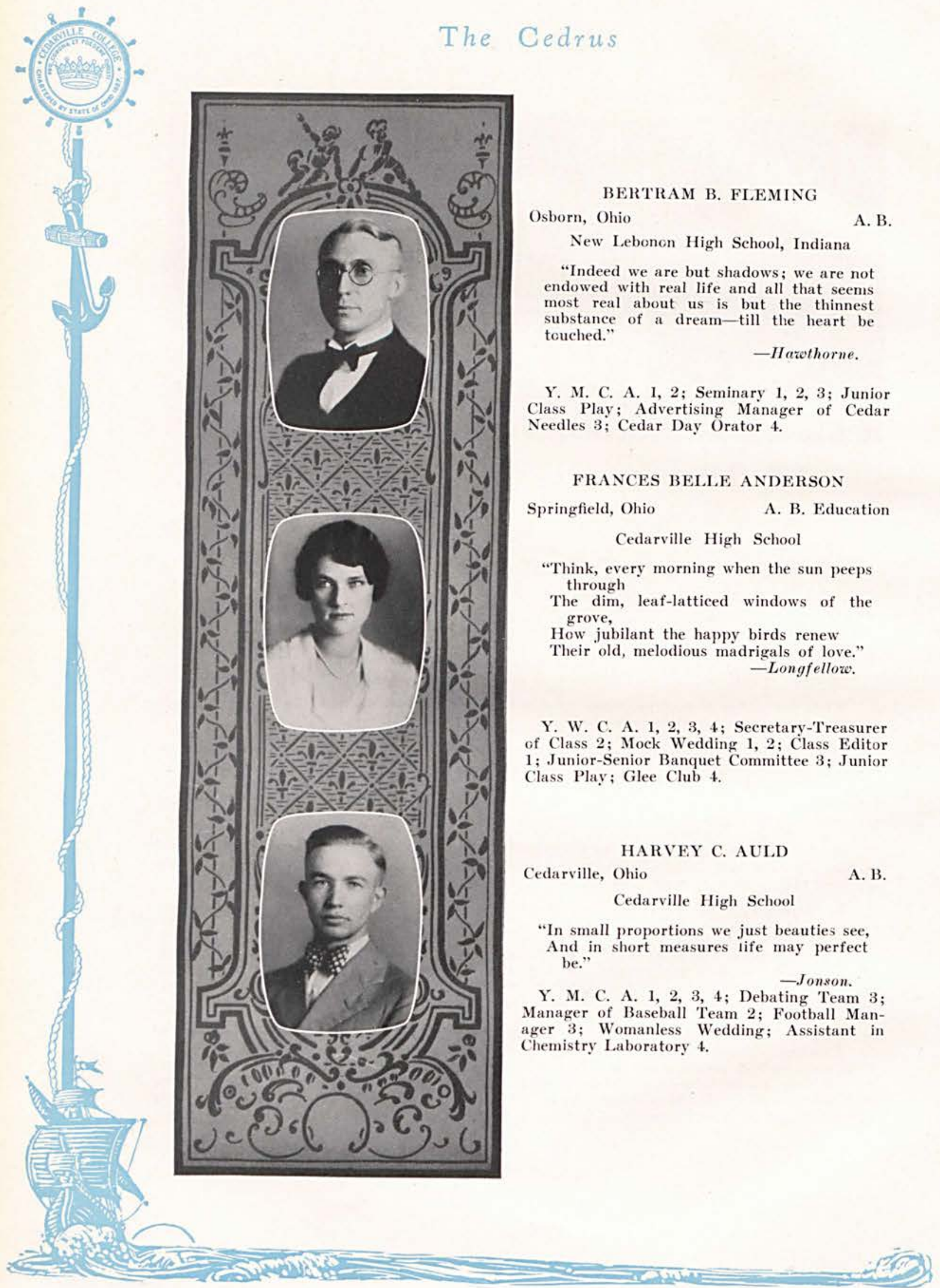

Page Twenty-six 


\section{The Cedrus}

\section{JAMES S, BEAM}

Xenia, Ohio

A. B. Education

Spring Valley High School

"Oh, honest face which all men knew!

Oh tender heart but known to few !"

-Stoddard.

Y. M. C. A. 1, 2, 3, 4; Cabinet Member 2; Program Chairman 4; Philosophic Literary Society 1, 2, 3, 4; Vice-President 3; Treasurer 4; Football Manager 2, 3, 4; Zoology Laboratory Instructor 3; Womanless Wedding 2; JuniorSenior Banquet Committee; Junior Class Play ; Class Treasurer 3; Vice-President 4; Cedar Needles Staff 3; Minstrel 3; President of Student Body 4; Advertising Manager of $\mathrm{Ce}$ drus 4.

\section{IRENE GRACE SHANNON}

Ashtabula, Ohio

A. B. Education

Ashtabula Harbor High School

"There is beauty in the sunlight, And the soft blue beam above;

Oh, the world is full of beauty

When the heart is full of love."

$$
\text { -Smith. }
$$

Y. W. C. A. 1, 2, 3, 4; Secretary 2; U. G. Representative 3; Vice-President 4; Glee Club 3,4 ; Orchestra 1, 2, 3; Otterbein Conference 1; Basketball 1; Manager 2, 3, 4; Cedar Needles Staff 3, 4; Cedrus Staff 2, 3, 4; Class President 2; Junior-Senior Banquet Committee; Junior Class Play; Mock Wedding 1, 2, 3, Bride 4; Philadelphian Literary Society 1, 2, 3; Girls' Student Council 2, 3; Chairman 4; Physical Education Instructor 3, 4; Cedar Day Dance Committee 2, 3, 4 .

\section{JAMES A. LEMON}

Morning Sun, Ohio

A. B. Education

Israel Township High School

"Every man stamps his value upon himself. The price we challenge for ourselves is given us.

Man is made great or little by his own will."

$$
\text { -Schiller. }
$$

Y. M. C. A. 1, 2, 3; Wittenberg Conference 2; Baseball Manager 1, 2, 3; Miami University Summer School 1, 2; Womanless Wedding 1; Orchestra 1, 2; Joke Editor, Cedar Needles 2; Business Manager; Assistant in Plane Geometry 2; Minstrel 2; Business Manager of Cedrus 3 .

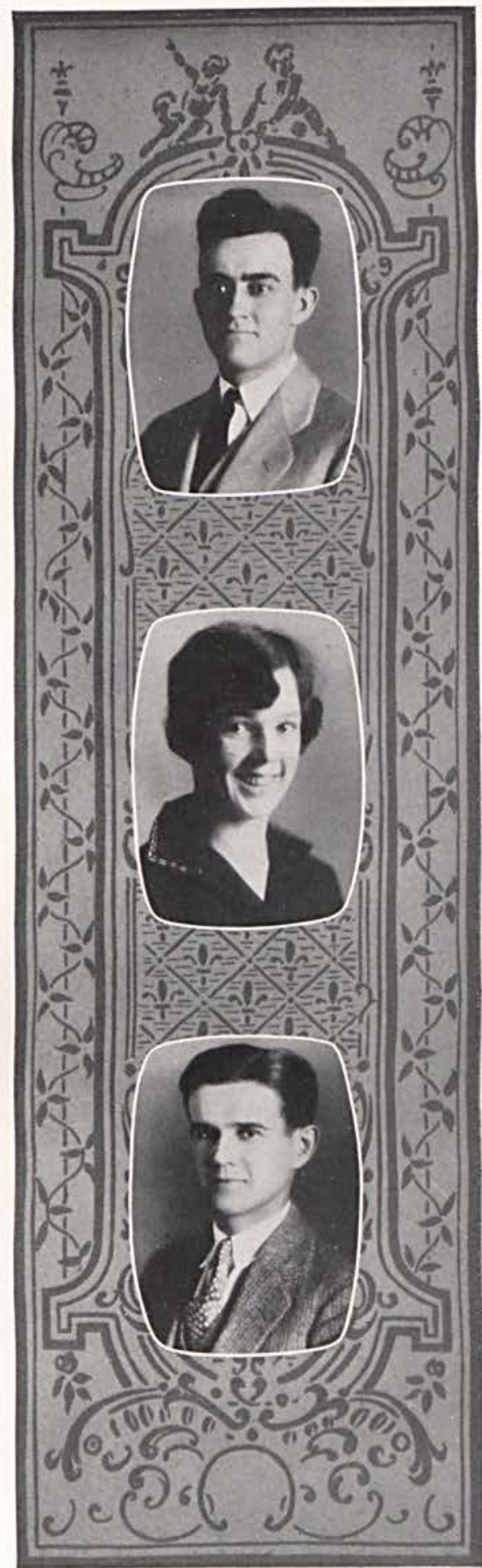

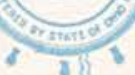

$\frac{1}{3}$ 


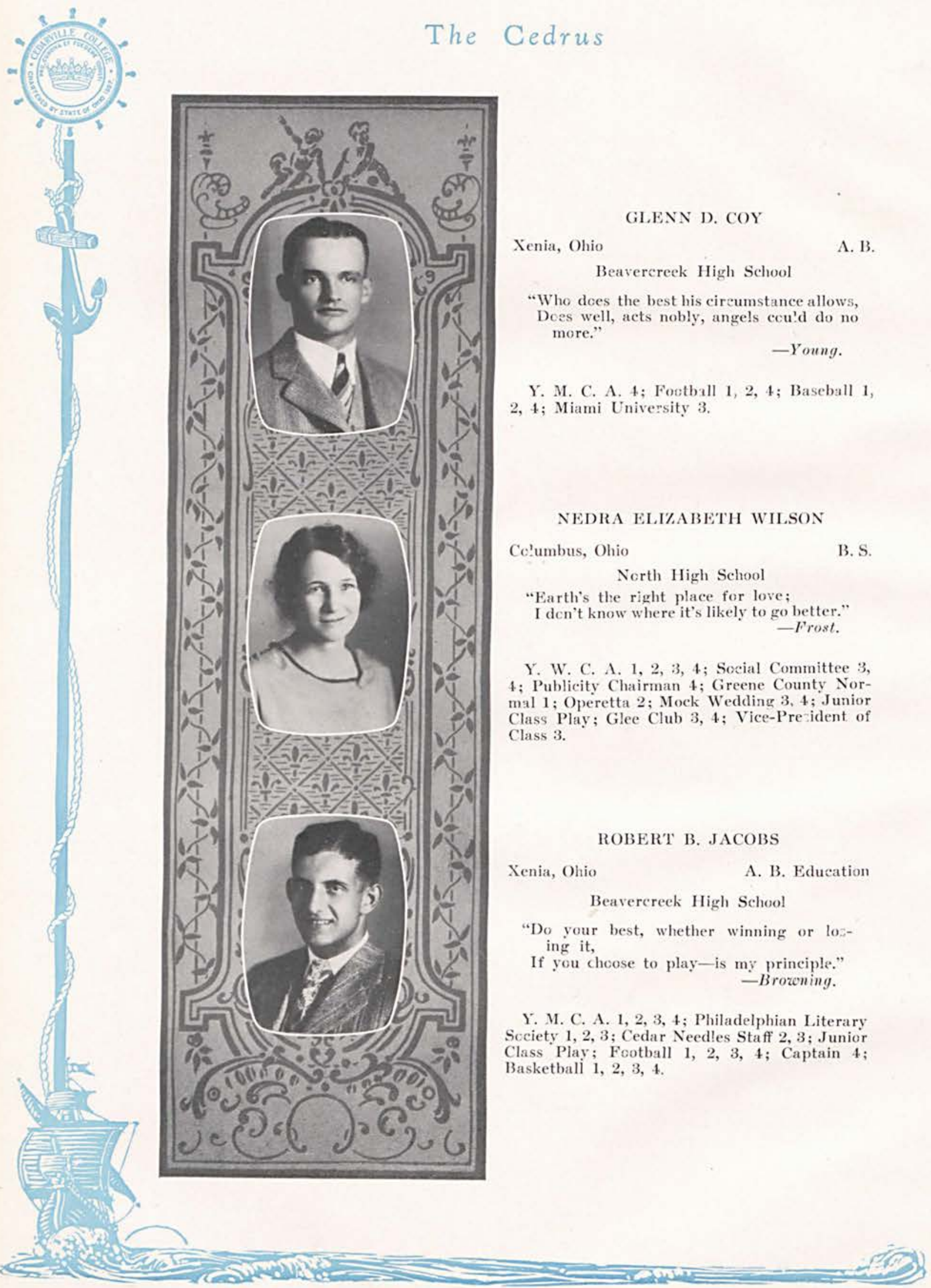

Page Twenty-eight 


\section{The Cedrus}

CI.AIR V. MCNEEL,

Altowna, $\mathrm{Pa}$.

Cedarviile Preparatory School

"Our times are in his hand

Who saith 'A whole I planned;

Youth shows but half. Trust God, See all nor be afraid.'"

-Browning.

Y. M. C. A. 1, 2, 3, 4; Chairman of Gospel Teim $2,3,4$; Conference at Wittenberg College 3; Philosophic Literary Society 2, 3, 4; Claplin 3,4 ; Womanless Wedding 2 ; Seminary Club 2; Conference at Lane Seminary 1 ; Seminary 4.

\section{MARGARET ALICE CHANDIER}

Cleveland, Ohio

A. B. Education

West High School

"From the fields of her soul a fragrance celestial ascended,

Charity, meekness, love and hope, and forgiveness and patience."

\section{-Longfellow.}

Y. W. C. A. 1, 2, 3, 4; Mock Wedding 1, 2; Cedar Needles Staff 3 ; Secretary of Class 3 ; Junior Class Play; Chairman of Junior-Senior Banquet Committee 3; Cedrus Staff 4; Pre ident of Class 4; May Queen 4.

HEBER E. KEACH

Jamestown, Ohio

A. B.

\section{Bowersville High School}

"I with my fate contented, will plod on And hope for higher raptures, when life's day is done."

-Wordsworth.

Y. M. C. A. 2, 3, 4; Junior Class Play.
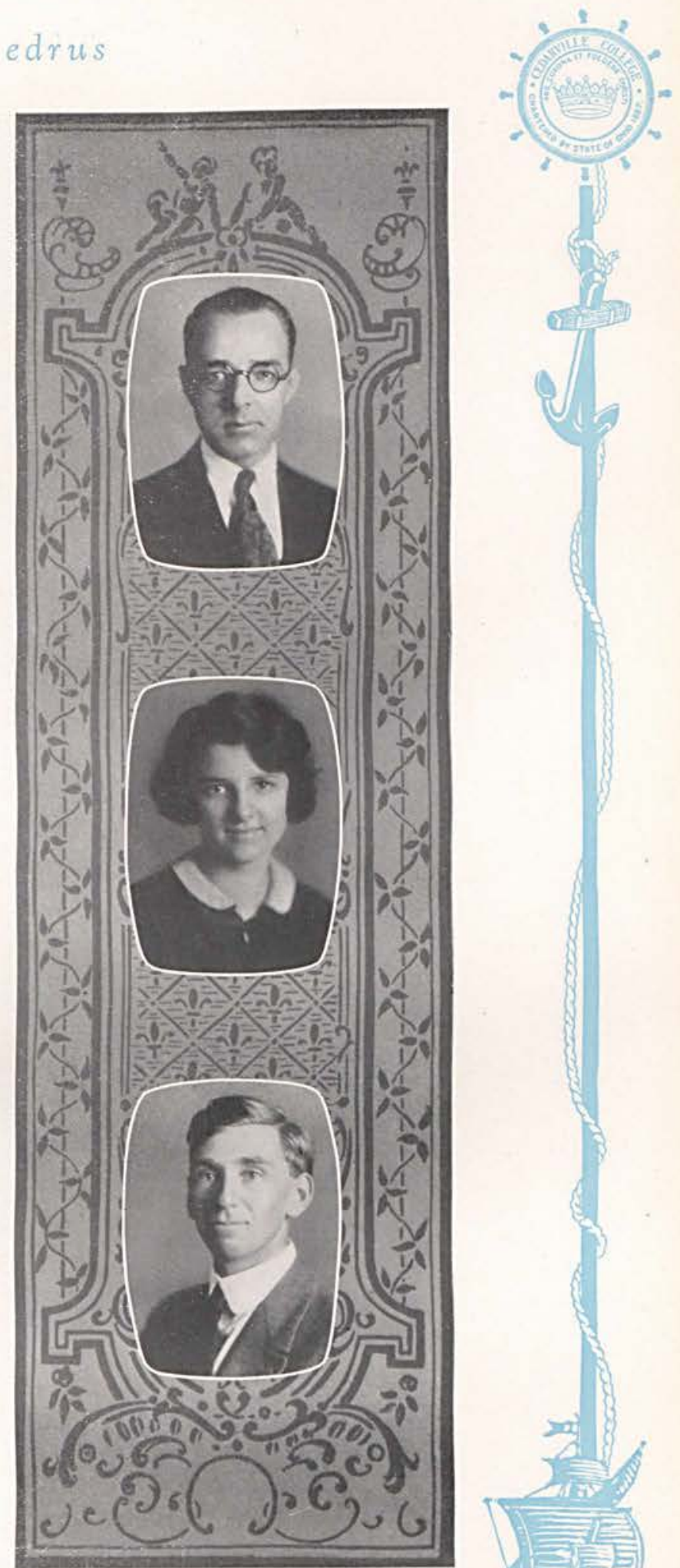

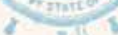

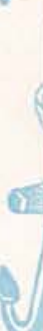

2.3 3

sis

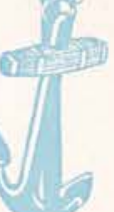




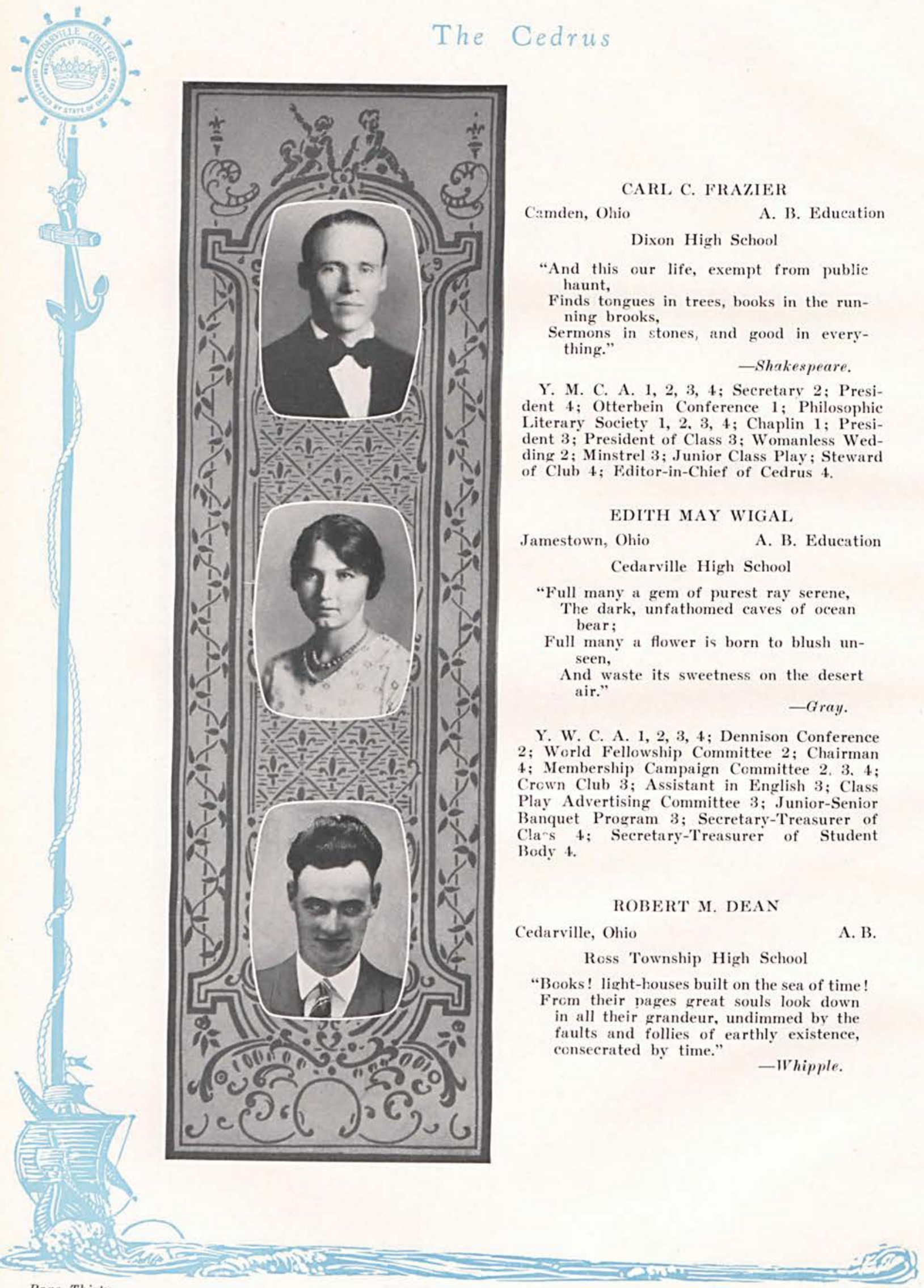

Page Thirty 


\section{The Cedrus}

\section{Senior Farewell Song}

We have come to the end of a perfect dayOur school days now are o'er,

But strange tho it seems, there are none of us gay With Commencement at our door.

For four long years we toiled for this day; And, oh, how long it did seem.

Now the goal is won-our books laid away-

There are tears where smiles should beam.

Yes, this is the end of a perfect day,

But it brings its sorrows, too,

For tho we are proud to be going away,

We are sorry to leave you, too.

Our friends are the ones who make life glad, As we climb the steepest hill;

It makes us so lonely, so serious, so sad, And loath to leave Cedarville. 


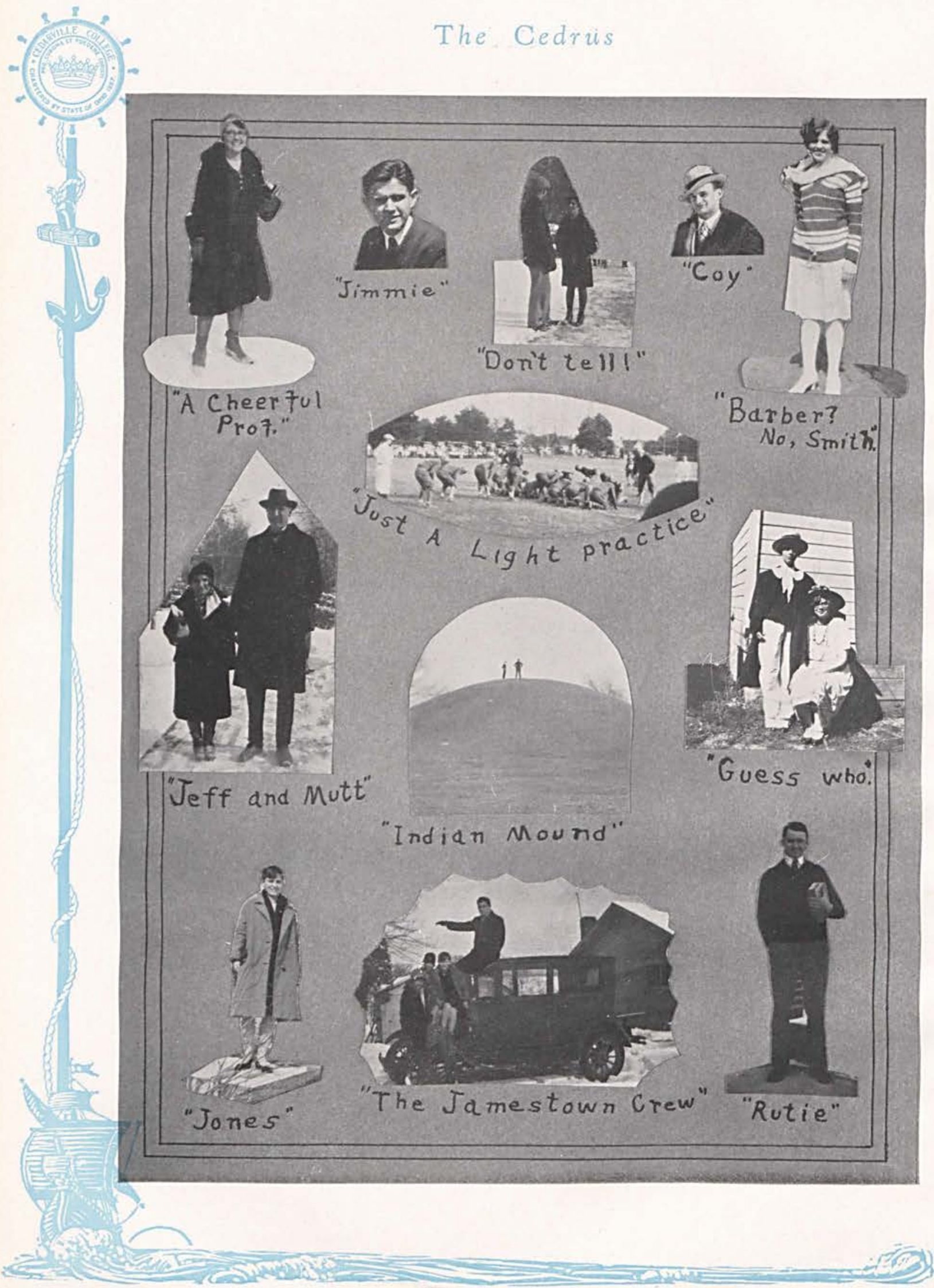

Page Thirty-two 


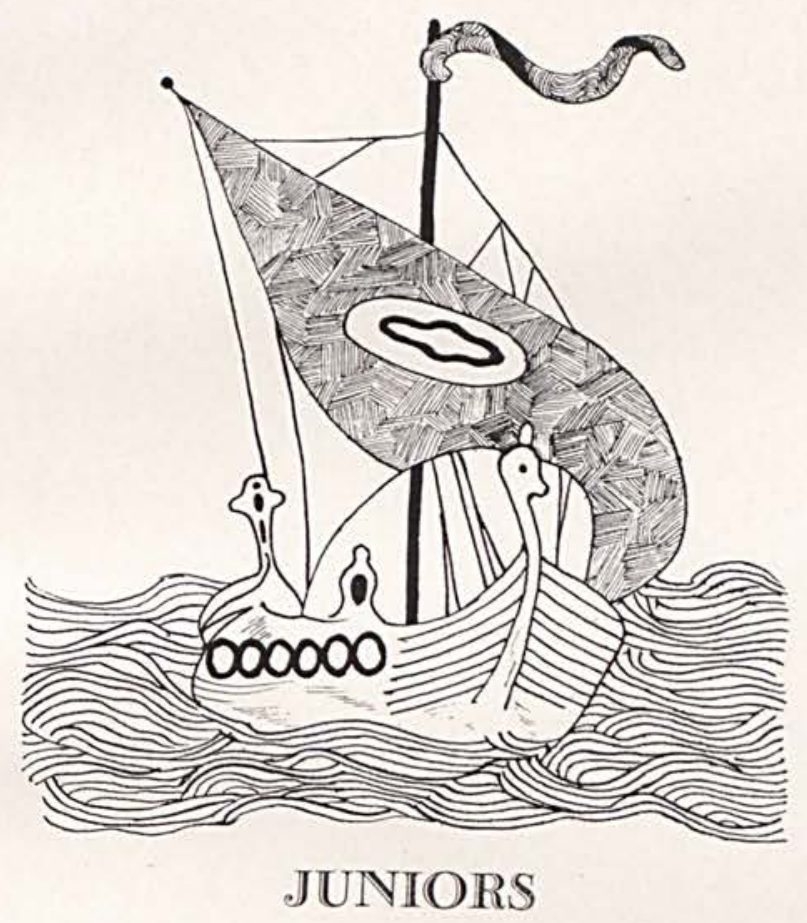

Page Thirty-three 



\section{The Cedrus}

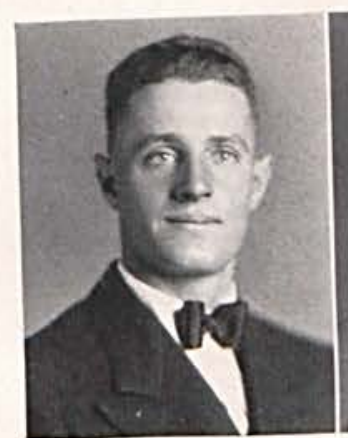

TANNER

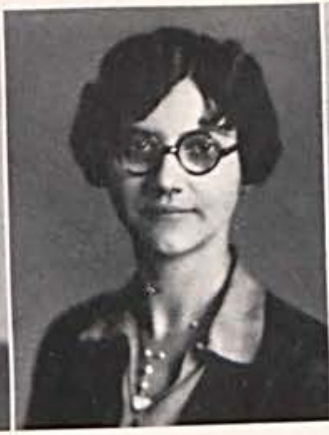

FANNING

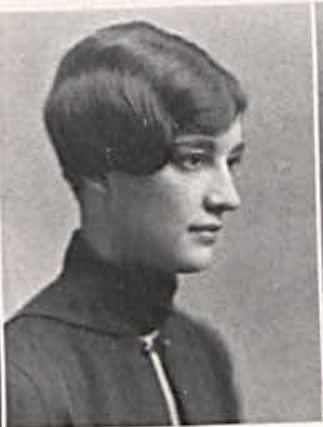

WOLFF

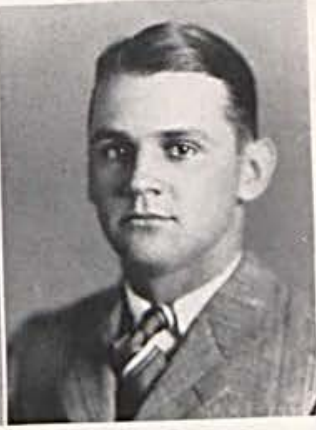

BRASEL

\section{Junior Class}

Paul Tanner

President

Blair Brasel

Vice-President

Dorothy Wolff

Treasurer

Dorotha Fanning

Secretary

We, the Juniors, have just completed our third and most interesting year at We started the year with a small decrease in the number of Cedarville College. We started the year with a smatl decrease Normal Students who
students who were with us last year, due partly to the Norm graduated.

However, our ciass this year is one of the peppiest classes in college, and is sure to be heard of for a number of years after we have left our dear old Alma Mater.

Our class stands for better school spirit, improved morale, and greater cooperation between students and faculty.

Only one more year, and the Class of ' 30 will pass into the wide, cruel world which it will try to conquer. not fail.

We will ever keep before us the moto, "Service for Others," and we can- 


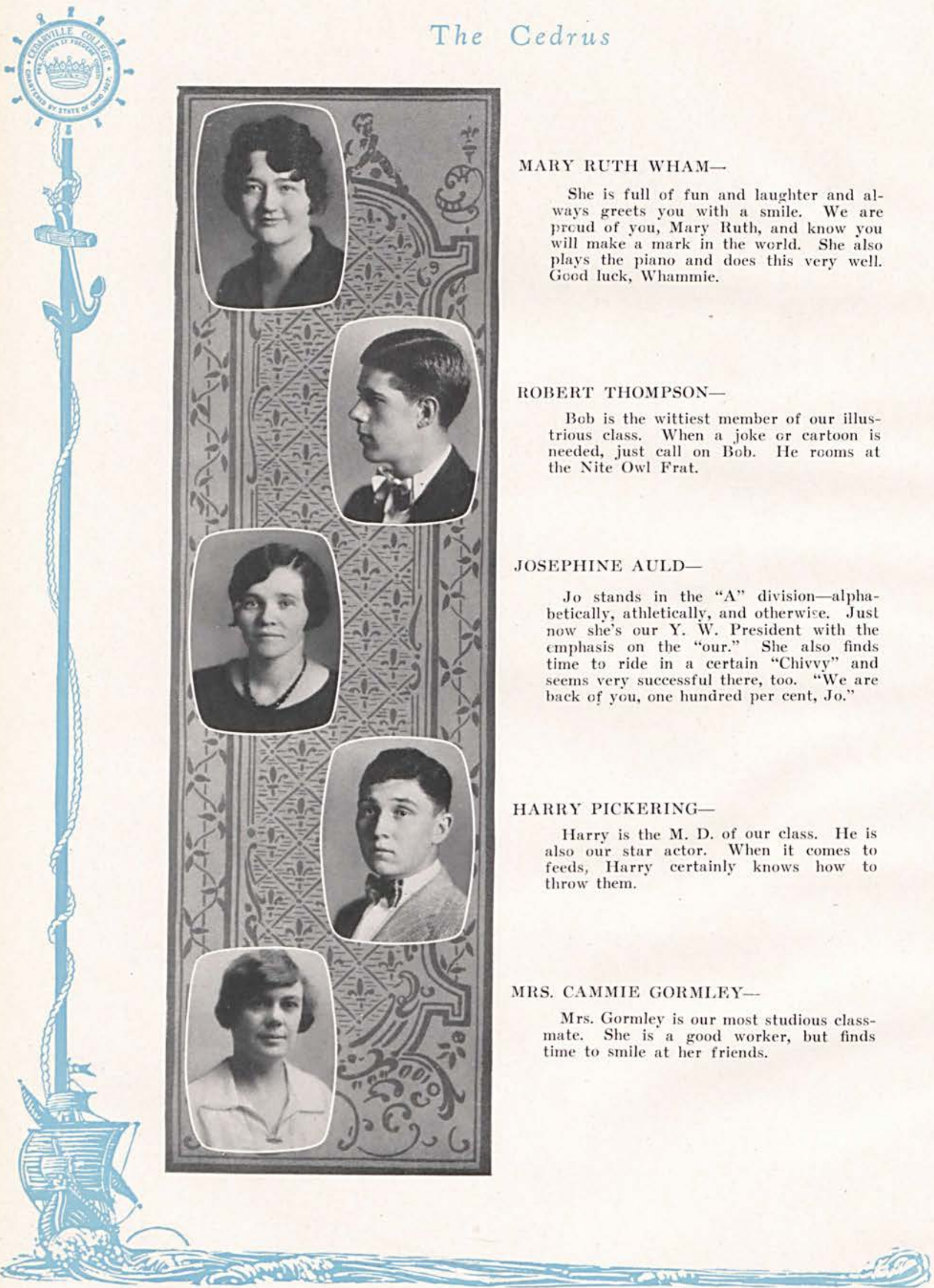

Page Thirty-six 


\section{The Cedrus}

\section{BETTY HAYDOCK-}

Betty is one of our dependent toilers, never crabbing. Her heart is gone, too. It's all right to trade even, isn't it, Betty?

\section{ROGER STORMONT-}

Roger is one of the latest additions to our number, but he is just as faithful to the class of 30 as he is in handing out the mail and making special deliveries.

\section{BETTY BADSTUBER-}

One of the jolliest lassies in the class. She may be short, but that doesn't keep one from wearing jewelry, does it, Betty?

\section{BLAIR BRASEL-}

Blair is one of our best students. $\mathrm{He}$ hails from Illinois, drives a "Chivvy," and is interested in the Y. W.

\section{LILLIAS FORD-}

Lillias is one of our most faithful class mates. When you want anything done, just ask Lillias. If she says, "yes," you can depend on it being done, and done well.
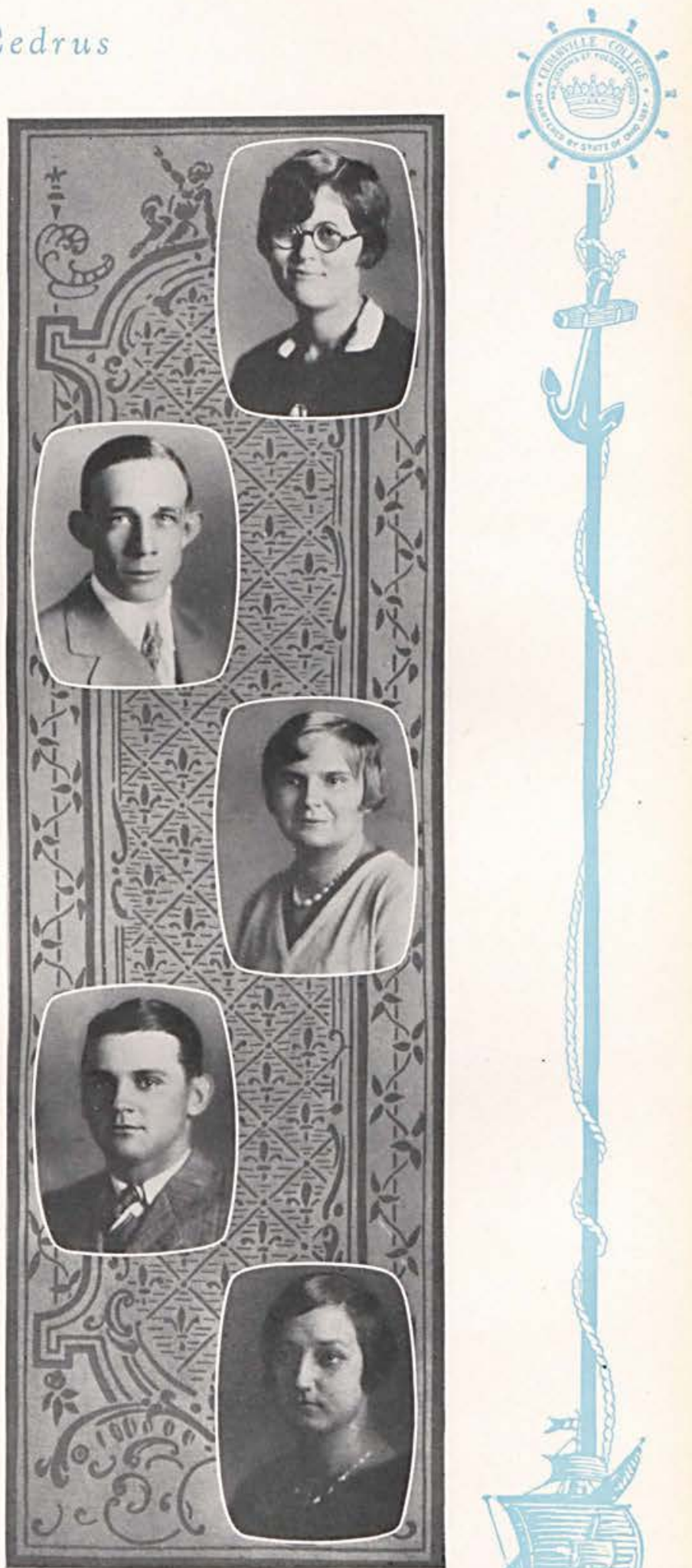


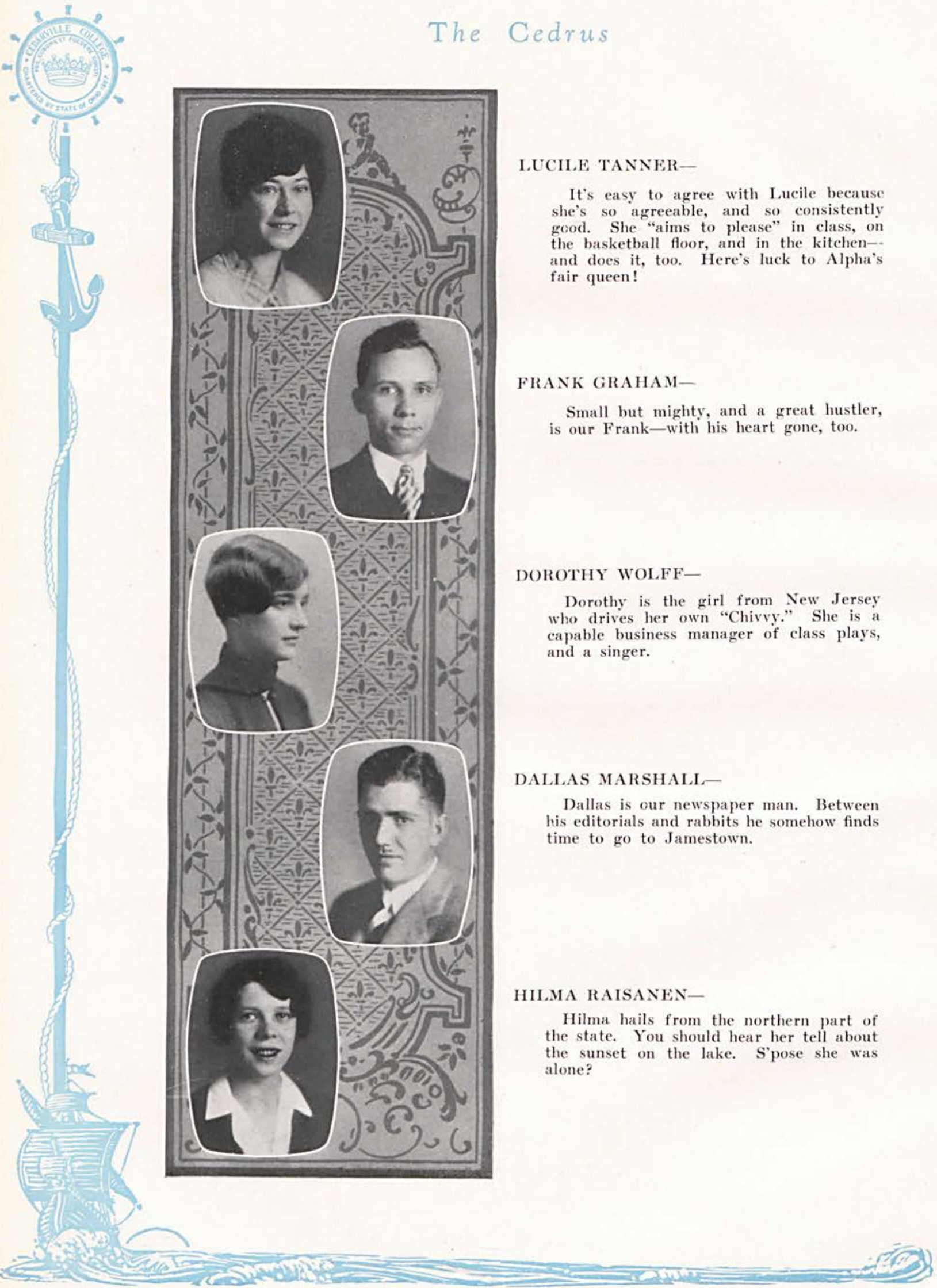

Page Thirty-eight 


\section{The Cedrus}

\section{JEAN MORTON-}

Jean, the life of the class, has a smile for everyone. She never misses a party, of any kind.

\section{PAUL TANNER-}

Our President, and oh what a job! Junior play, Junior-Senior Banquet, and a popular clamor for feeds keep Paul busy. He is doing a good job of it.

\section{FRANCES MeCHESNEY-}

Very capable and stands first in all her classes. She has served the Y. W. as program chairman and done it well. A ficrson upon whom you may depend, and her word is as good as gold.

\section{JAMES STORMONT-}

Jim will not be with us next year. We understand that he is going to fly high, wide, and handsome. Good luck, Jim!

\section{JANIS CARTER-}

Jolly Janis! It is impossible for the "Blues" to overcome her laughter. And her saxophone has added to many a program at C. C.
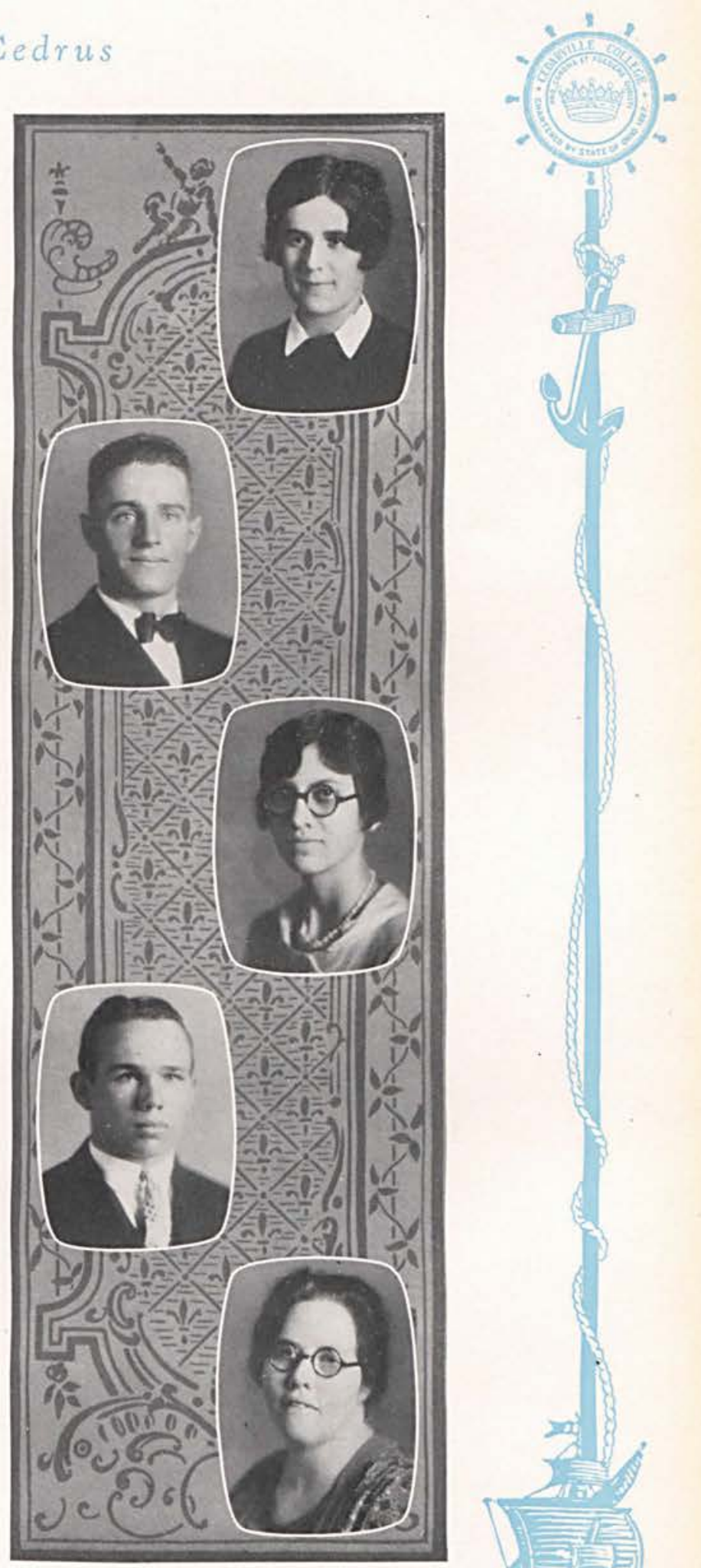


\section{The Cedrus}

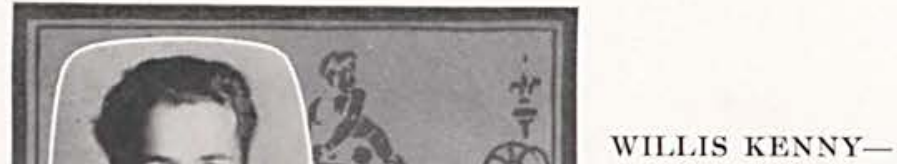

Willis is the football star from Wellsville. He likes Cedarville very well. Many believe that he likes someone nearer home, too.

DORTHA FANNING-

Dortha comes from Jamestown, and drives her own Ford. She is a very promising actress, and, oh my! that black curly hair!

\section{PAUL ARMSTRONG-}

Paul comes from the fair town of Osborn. He likes to sleep pretty we!l, and we wonder if that causes him to be late at classes occasionally.

\section{FRANCES BRADLEY-}

This is the first year that Frances has been with us. However, she has already proved her loyalty to the class.

\section{GEORGE GORDON--}

George is our basketball star. When it comes to the hardwood he is right there, but as to classes, that is something different. 


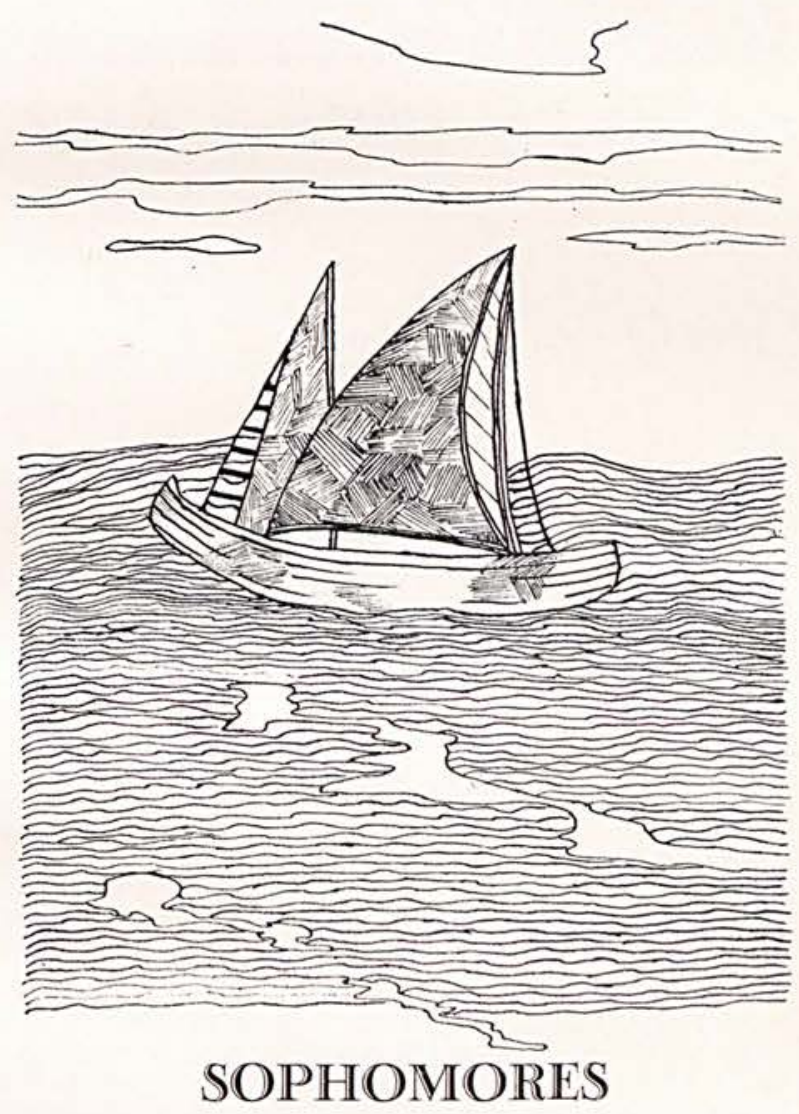





\section{The Cedrus}

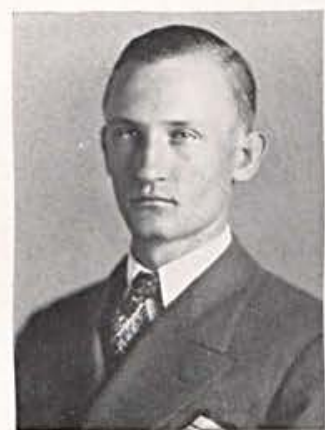

LYON

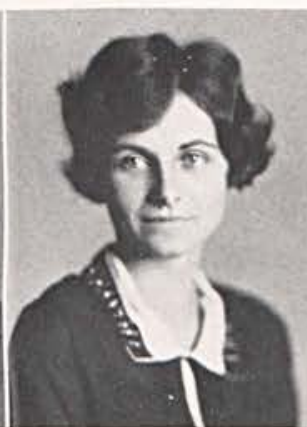

LEACH

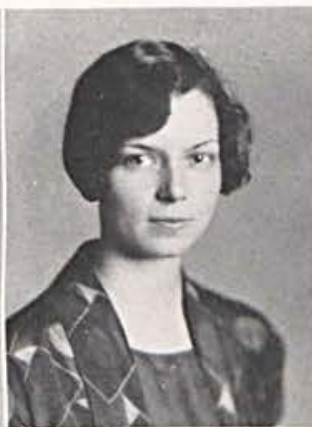

SNYDER

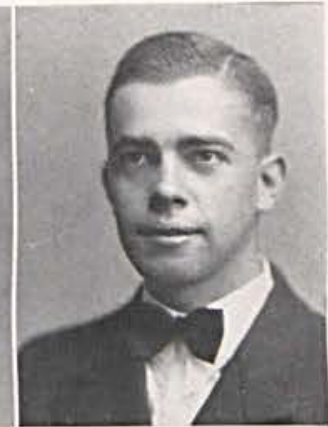

FOSTER

\section{Sophomore Class}

Silva Lyon

President

Lorna Leach

Vice-President

Joseph Foster

Secretary

Alberta Snyder

Treasurer

The second year of our sojourn at C. C. is drawing to a close. We have in these two years made a name for ourselves that shall long be remembered. Now, do not think us egotistical. We realize our shortcomings as well as our merits, but we believe the world has faith in those who have faith in themselves. We have kept that faith. Now we endeavor to convert the world.

We are an intellectual lot. If you doubt this, hunt up our scholastic records. We do not profess to be book-worms-our aim is not to let studies interfere with our education.

We are mighty. We took the freshmen scaips with little trouble, and less fuss. Our reputation had preceded us, and when the freshies saw the determined glint in our eye they became as so many lambs led to slaughter. Our feeds we have conducted with dignity and with pomp and glory, undisturbed by any attempt at rushing.

We are athletic. Cedarville will long remember our contributions on the football field, on the basketball floor, on the baseball diamond, and on the sidelines-the cheerleader was one of us, and we are proud of them all. She will not soon forget the glorious sophomore victory, March 28, when both the boys and girls were proclaimed champions of the College Interclass Basketball Tournament.

We would say more, but modesty is more comely than braggadocio. You will hear from us soon enough again. But wait! Hear us give one cheer-

Sophs! RAH! Sophs! RAH! RAH! RAH! SOPHS!!!

C. $\mathrm{F}$. 


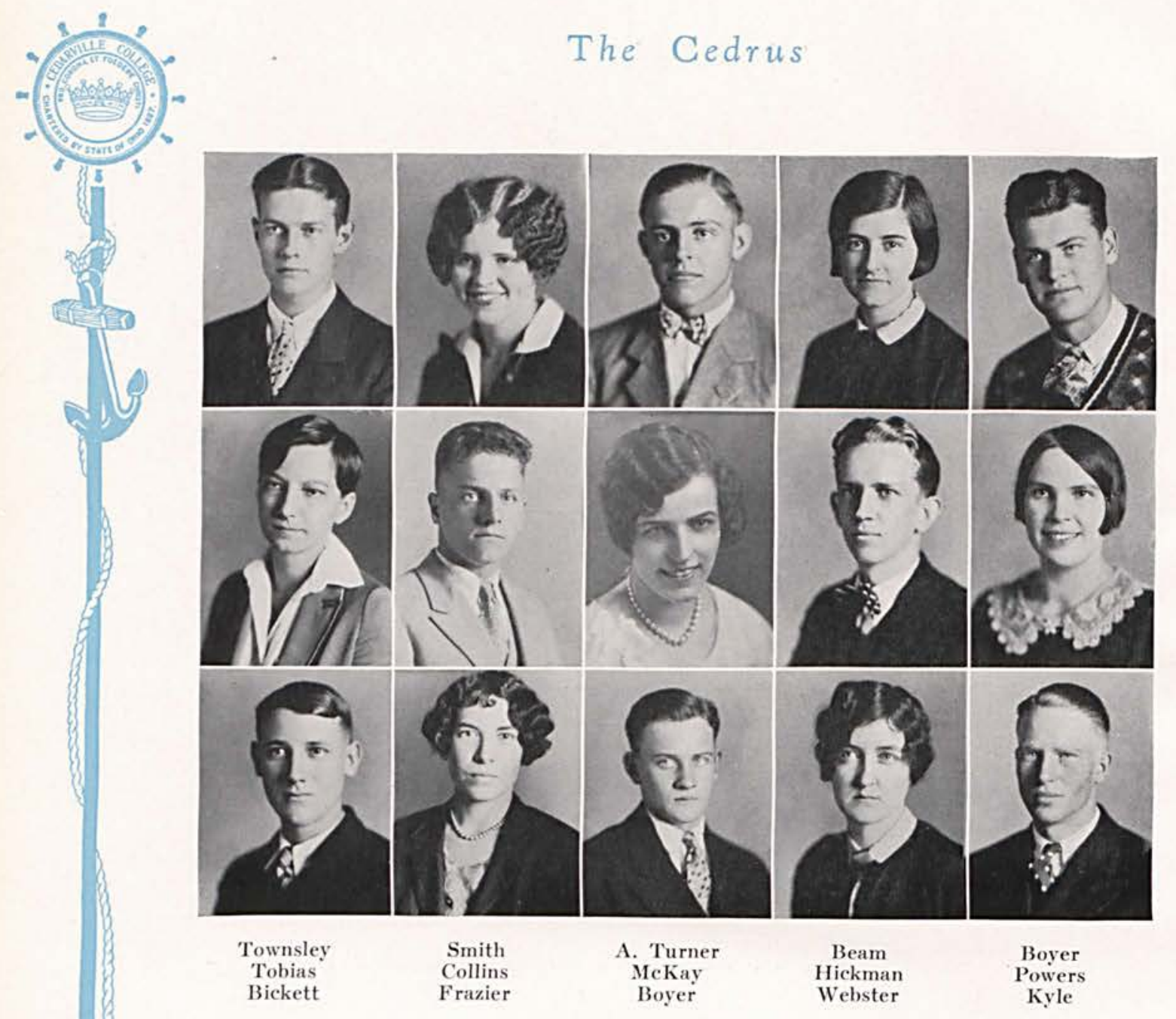

The sofa sagged in the middle,

The shades were pulled just so,

The family had retired,

And the evening lamp burned low.

There came a sound from the sofa,

The clock was striking two,

The freshman slammed his textbook, with a thankful

"Well, I'm through."

Page Forty-four 


\section{The Cedrus}

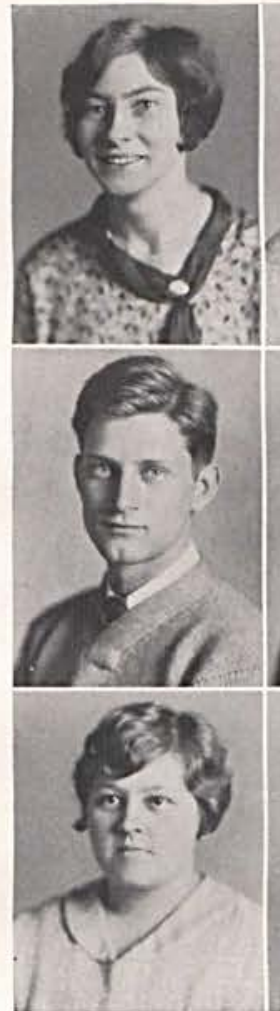

Van Pelt

Allen Rife
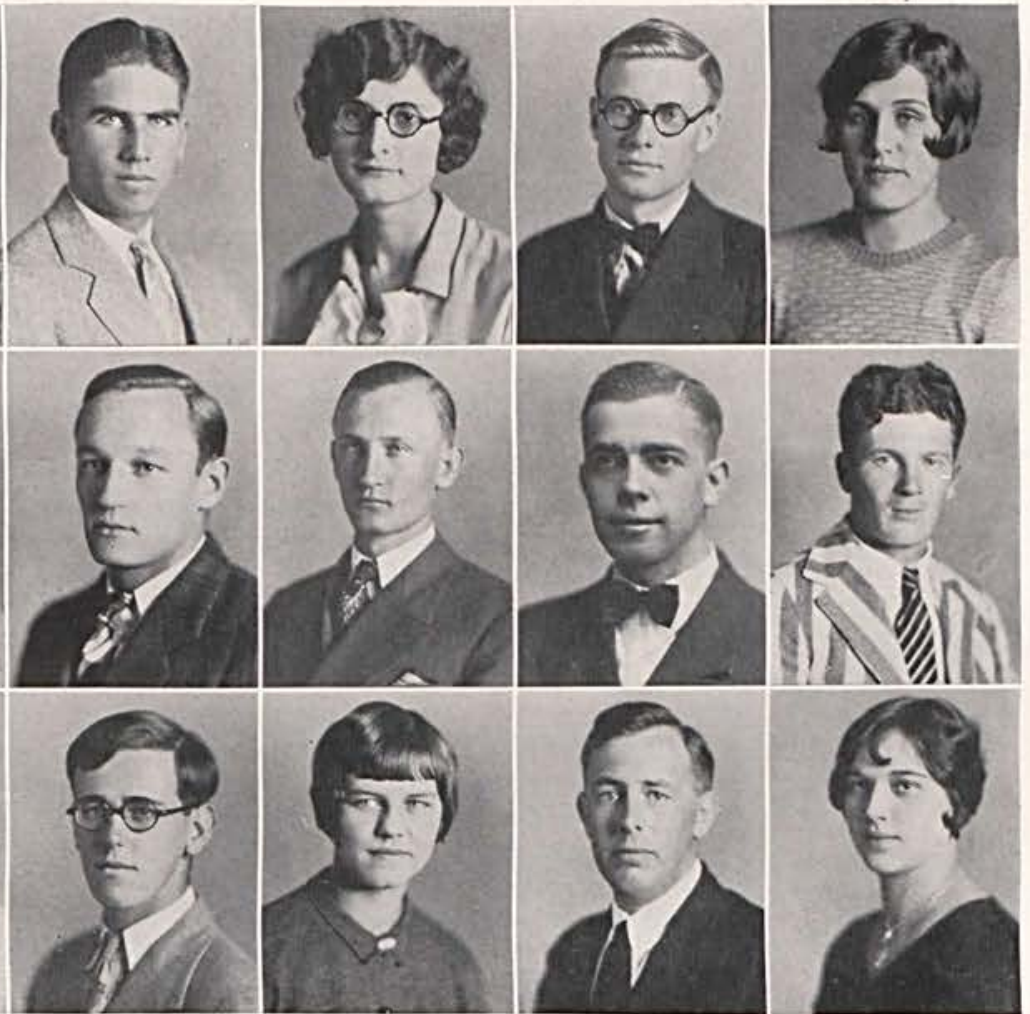

$$
\begin{aligned}
& \text { B. Turner } \\
& \text { Smith } \\
& \text { MeCallister }
\end{aligned}
$$

Carle

Lyon Curry
McDonald

Foster Mantle

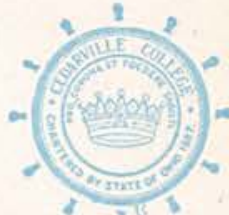

8
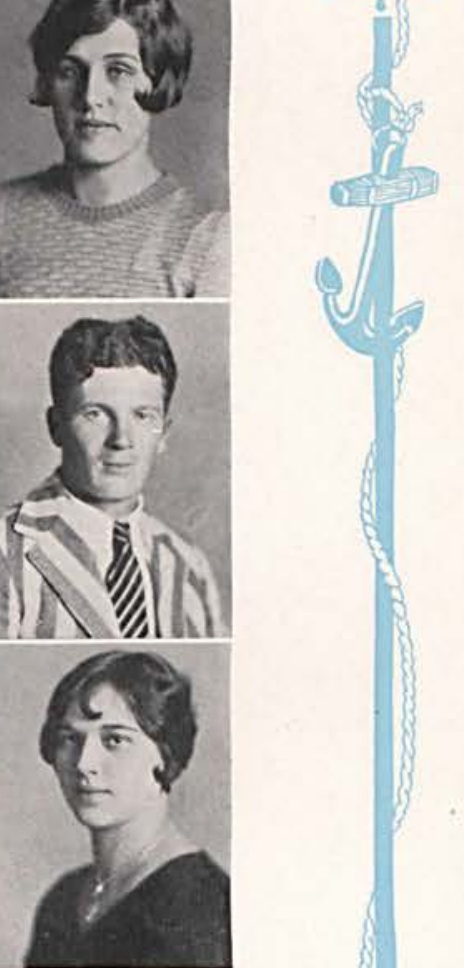

Kinney

Osborn

Rumbaugh

If you are calling - and

You see the lady yawn,

It is a hint she'd like

To get to bed 'fore dawn. 


\section{The Cedrus}

\section{In The Early Morn}

Oh, 'tis sweet in the hush of the early morn,

When the sunshine comes over the hill,

To think of the happy hours we've spent-

Fond memories haunt us still.

Oh, the joy of our glad awakening,

How we feel like shouting and singing,

We are prompted to thank the God of Love

For the day and the joy it's bringing.

The forces of teeming nature land

The Omnipotent ruler of all;

And if we but listen and calmly wait,

We can hear His stirring call.

We find it thus whenever we roam

In the beauty of God's outdoors;

When we pause and turn to Him in faith,

He heals our heartaches and sores.

And if we are striving to live as we should

And succeed in our toil and play,

We'll commune with God in the early morn,

For He'll give us the strength for the day.

G. W. DAVIS. 

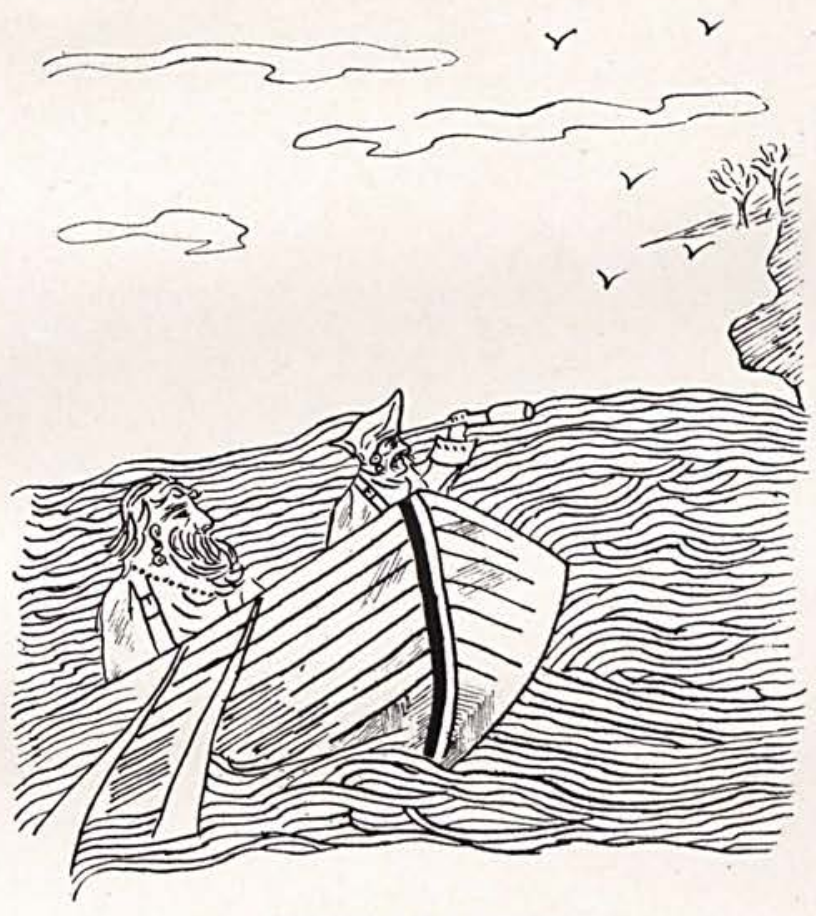

FRESHMEN

Page Forty-seven 



\section{The Cedrus}

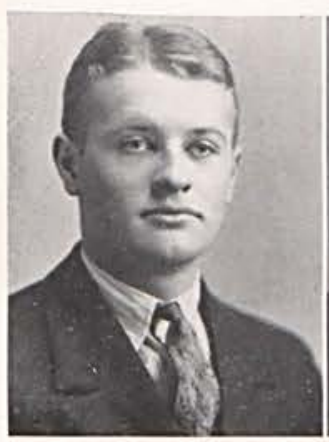

NORTH

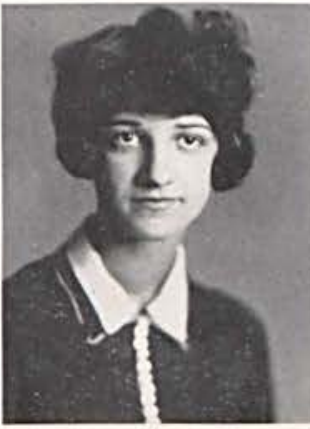

PHILLIPS

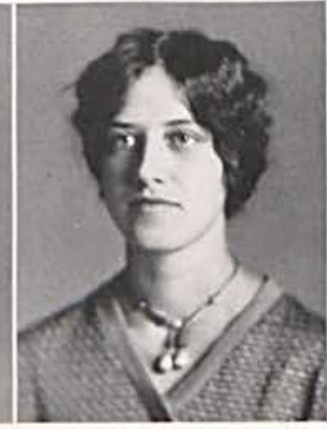

HARTMAN

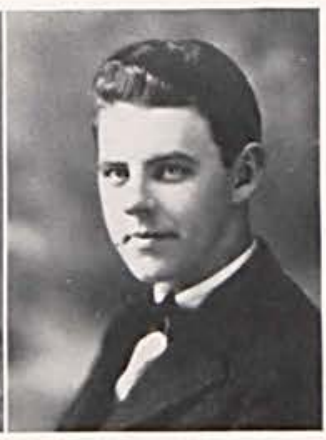

REED

\section{Freshman Class}

William North

President

Arcelia Phillips

Vice-President

Esther Mae Hartman

Secretary

Leo Reed

Treasurer

On September 12, 1928, about fifty shy little Freshmen appeared on the College Campus for the first time, and tried their best to make a favorable impression on the upper classmen. The boys undoubtedly did, for they even gave them hair cuts free of charge, for which we wish to thank them. The Freshman Class of '28 did its share of helping both the football and basketball teams and our hopes are high for our baseball stars. We are proud of our Freshie athletes.

Green bibs? Yes, they are among our souvenirs.

Walk home barefooted? Yes, we like it.

Freshmen? Yes, but hope to stay to be Seniors. 


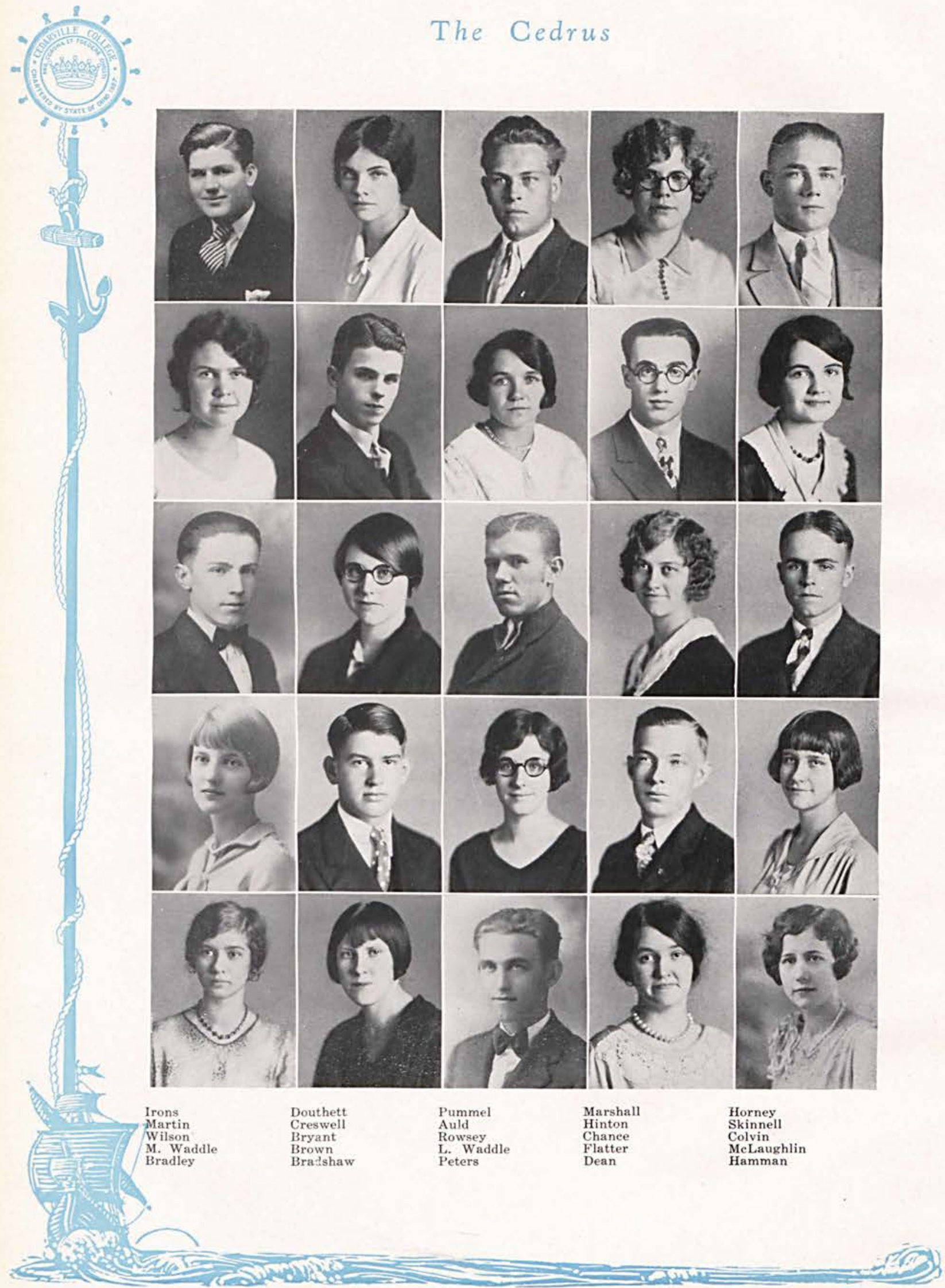

Page Fifty 


\section{The Cedrus}

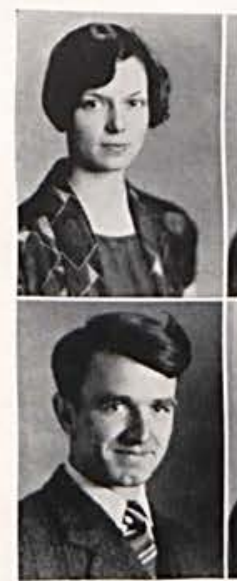

Snyder Rutan

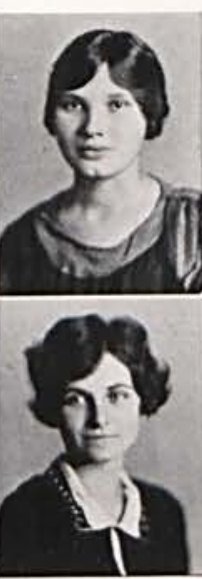

Wigal Leach
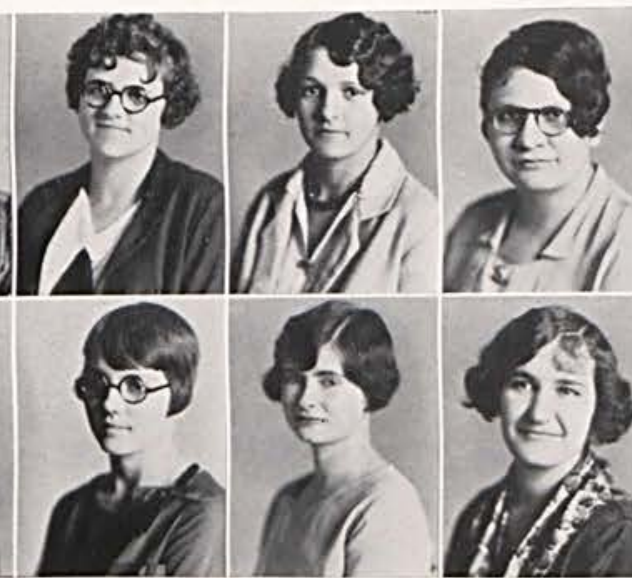

Gilmore Kennedy

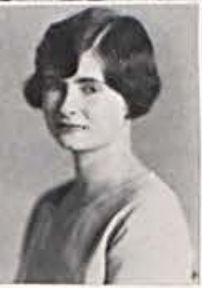

Jones

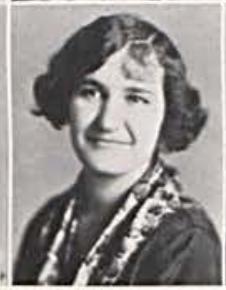

Clark Sortman
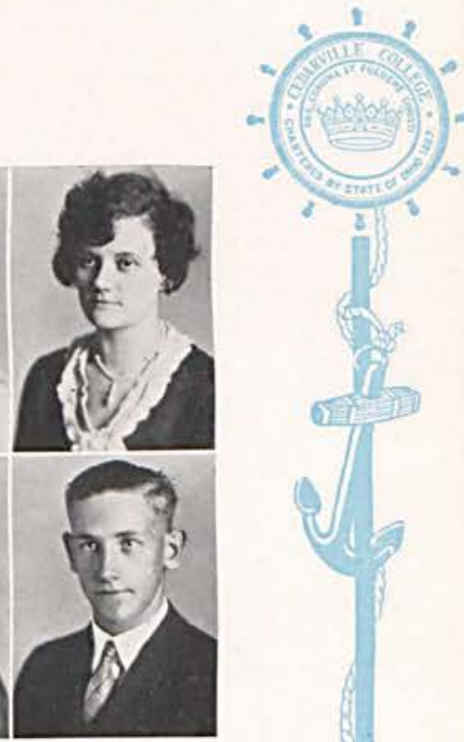

Scott

Hollingsworth

\section{Second Year Normal}

"To teach, or not to teach; that is the question;

Whether 'tis nobler in the mind to suffer

The slings and arrows of outrageous parents,

Or to take arms against a sea of troubles

And by marrying (?!?) end them."

$$
\text { With A pologies to Shakespeare. }
$$

The Normal Class of 1929 has already decided the above question and as June draws nearer we wonder if, after we have received that long, hard-earned, coveted sheepskin, we will be able to withstand those "slings and arrows" which are aimed toward us.

When we entered college in 1927 it was not long before the faculty and others could pick out the "Normal Class" for we have held our own at class feeds, sports, and all kinds of parades.

We found our number had decreased when we returned for our second year. There were those who felt the need of teaching that "innocent age of childhood" this year. All of us who returned pat ourselves on the back and remark- "quality counts."

Those who are surviving have found that it has not been an easy task to remain in this "Normal" Class, as there are so many requirements for membership. We do not dare leave a class five minutes after the bell has sounded - at least not since-well, just ask one of us to fill in the blank. We wouldn't think of going to class with unprepared lessons-it would be worse the next day. Neither would we try cutting class to snow-ball or play "Fox and Geese" in the winter, nor to cut class to roller-skate, even though spring is in the air. Does not this prove to you how hard it is to remain in a "Normal" Class?

For two years we have been co-sufferers together (profs included). Now looking backward, we remember some hot days, freezing days, good recitations, bad recitations, dumb errors, and blissful ignorance, but we only hope our profs will forgive and forget, for we are on-ly "Normals."

G. L. W. 


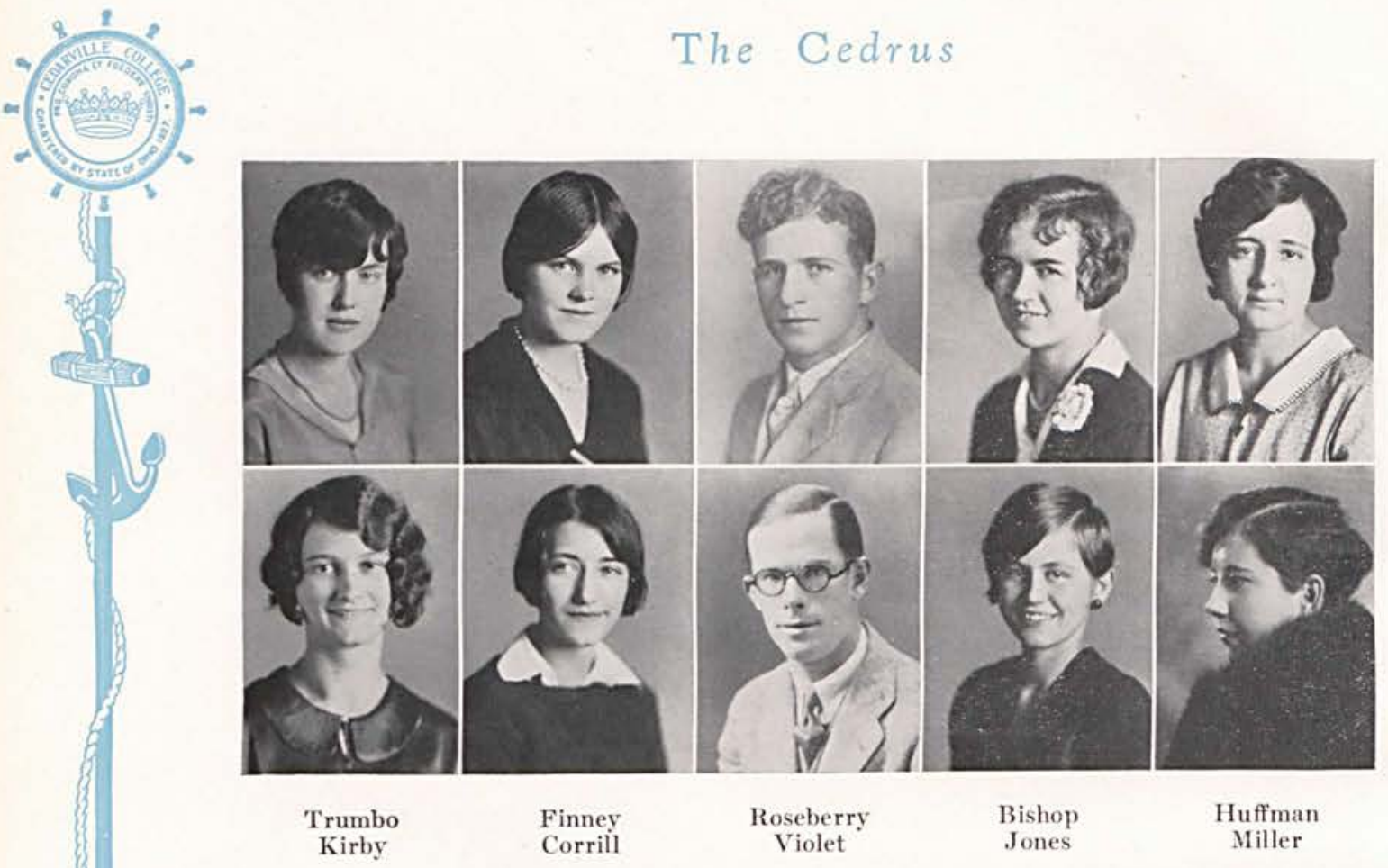

\section{First Year Normal}

Along about September 11, 1928, some few stalwart lads and lassies presented themselves at the gate of Cedarville College, to start, to begin, to commence, a one or two year Normal course. At the gate presided Mr. Entrance Exam. We were detained there for a few hours, but after due consideration on his part it was decreed that we might pass through.

In such a manner we became Freshmen. We wore the notorious bibs, considering that a great privilege. They were green, and what is so becoming and so cheerful (especially in the fall of the year, when everything else looks dead) as the color green? Yes, we had the fall of the year, when everything else ooks dead as doe for our great benefit-it saved our time, which is quite valuable. We did not have to take time off so often in order to get a haircut. The upper classmen were very considerate-maybe next year we can be as considerate-perhaps more so.

In athletics we didn't do so badly. We donated two girls to the basketball team. As our supply of boys was rather low, we could not spare any of them.

So, really, we aren't such a bad lot after all. We never lose our tempers unless we fail to control them. We're very studious, always studying if there is nothing else to do. We're always on time at class unless we are late or fail to come. We always respond in class when we know the response. In short-we are all right if you think we are!

R. J. 


\section{The Cedrus}

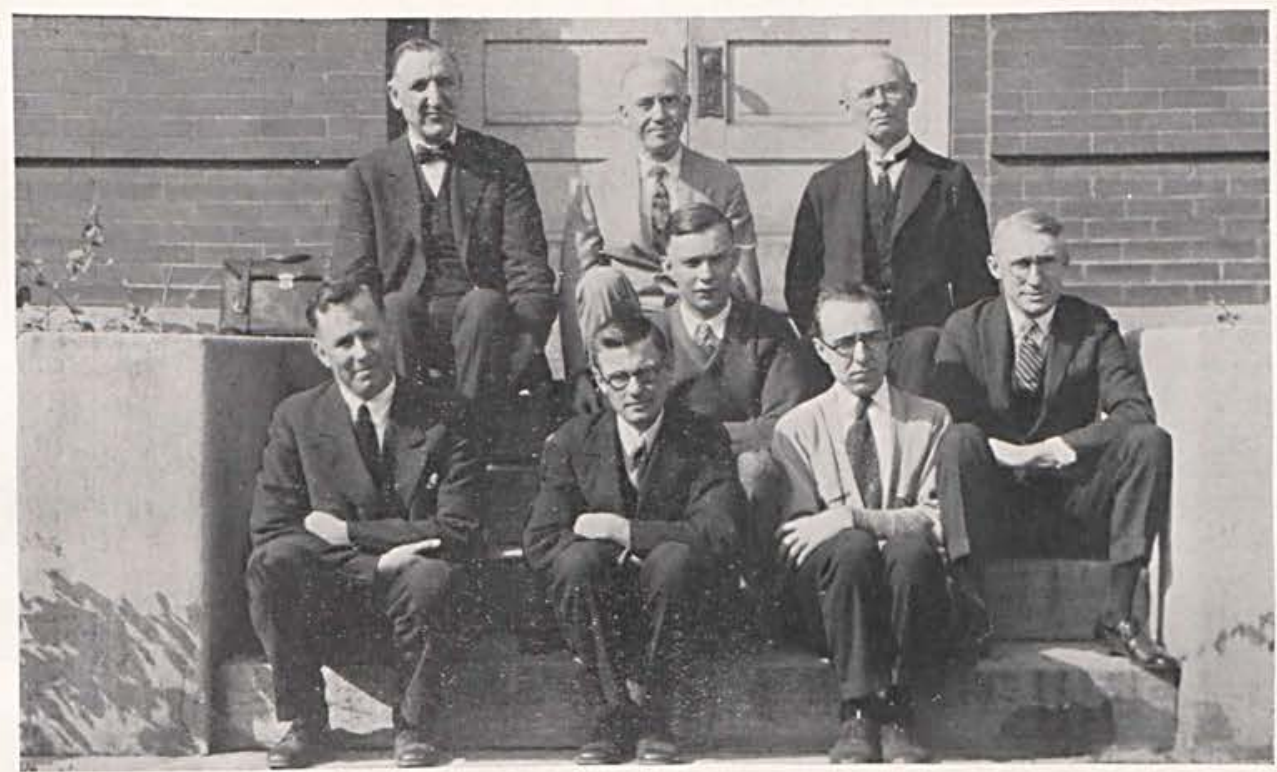

\section{Seminary}

Cedarville Theological Seminary offers a three-year course, at the end of which a diploma is granted, and in which the credits are accepted by the leading seminaries of the country.

A larger number of students were enrolled in the seminary this year than usual. Those attending seminary classes were B. B. Fleming, E. S. Wones, C. V. MeNeel, Howard Flatter, J. E. Rowsey, Myron MeDonald and W. N. Mantle.

The subjects offered included Systematic Theology, under Dr. W. R. McChesney, Comparative Religion and Homiletics, under Dr. Charles M. Ritchie, and OId and New Testament Literature, Church History and Greek, under Dr. F. A. Jurkat.

A splendid spirit of interest has prevailed, and the students are hearty in their praise of the manner in which the faculty has made clear many of the biblical and spiritual truths so much under discussion.

W. N. M.

Another year unfolds itself,

And Fleming, where is he?

A sailing down the river Styx?

Oh, say, how can this be?

Has Charon grown too old to row

His boat for you and me?

And Wones, God bless him, let him live In peace and happiness;

And let McDonald pass through life With portions of success;

And Mantle and the other boys Be filled with joyfulness.

G. W. D.

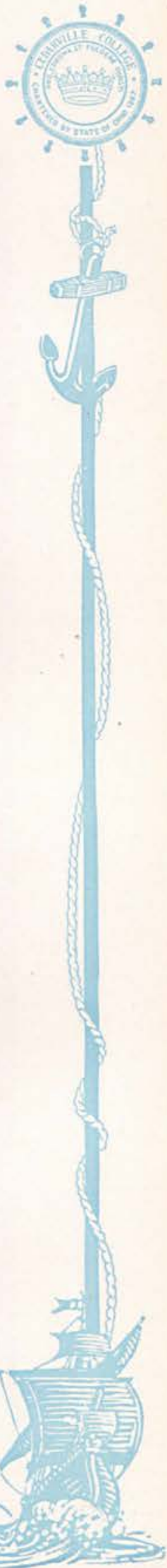




\section{Department of Music}

$\mathrm{T}$

HE studio of the department of music is located in the college library building which is but a short distance from the campus. The department is growing in more ways than one under the efficient guidance and instruction of Professor Lydia A. Berkley, M.M., B.M. Professor Berkley is a graduate of Lincoln Conservatory of Music and Hiram College Conservatory. She was a special student of Oberlin Conservatory of Music and Cincinnati College of Music. Professor Berkley was at the head of the organ department and instructor in piano in Bucknell University, Pennsylvania, and in Mansfield State Normal, Pennsylvania. Before coming here she was employed as head of the piano and organ department of Eton College, North Carolina.

Professor Berkley is assisted by Mrs. Helen Laughlin Corry, who is a graduate of the college of Wooster. Mrs. Corry is a very fine sopranist. She teaches most of the classes in theory and assists Professor Berkley in teaching piano and voice.

The courses offered this year are Voice, Piano, Harmony, Notation, Sightsinging, Ear training and History of Music. There is quite an improvement over the previous department because of the added number of subjects offered, the increase in the number of lessons a week, and the efforts being made by the professor and instructor of the department to put as much thorough work into the lessons as possible.

Professor Berkley has charge of the Girls' Glee Club, which is made up of more than thirty-five voices. Rehearsals are held regularly once a week. The club has appeared in public a number of times and has been received by very appreciative audiences. A public recital is given every two months, and a private recital every month. The purpose of these is to demonstrate the accomplishments of the department and to give the pupils an opportunity for public appearance. The value of these recitals to the pupils cannot be over-estimated.

The courses of study are outlined in such a way that, regardless of the number of years a pupil has studied, the degree of proficiency alone shall be the basis for recognition by the college in the granting of a diploma, showing that a prescribed course has been satisfactorily completed by the student. These courses should make strong appeal to the musically interested amateur as of great cultural value. There are plans in the making for better and more adequately equipped faculties in the department of music.

G. H 
The Cedrus
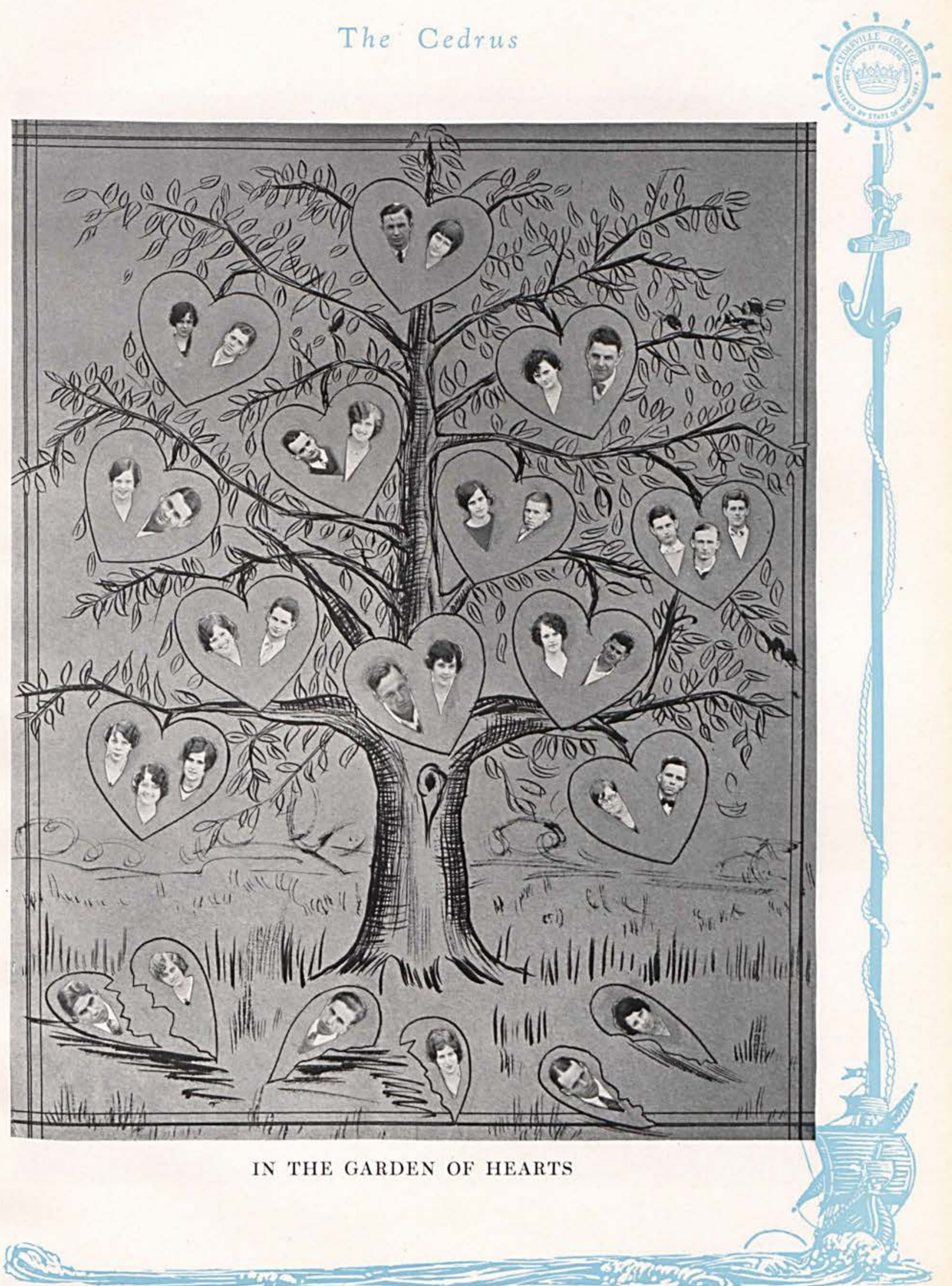


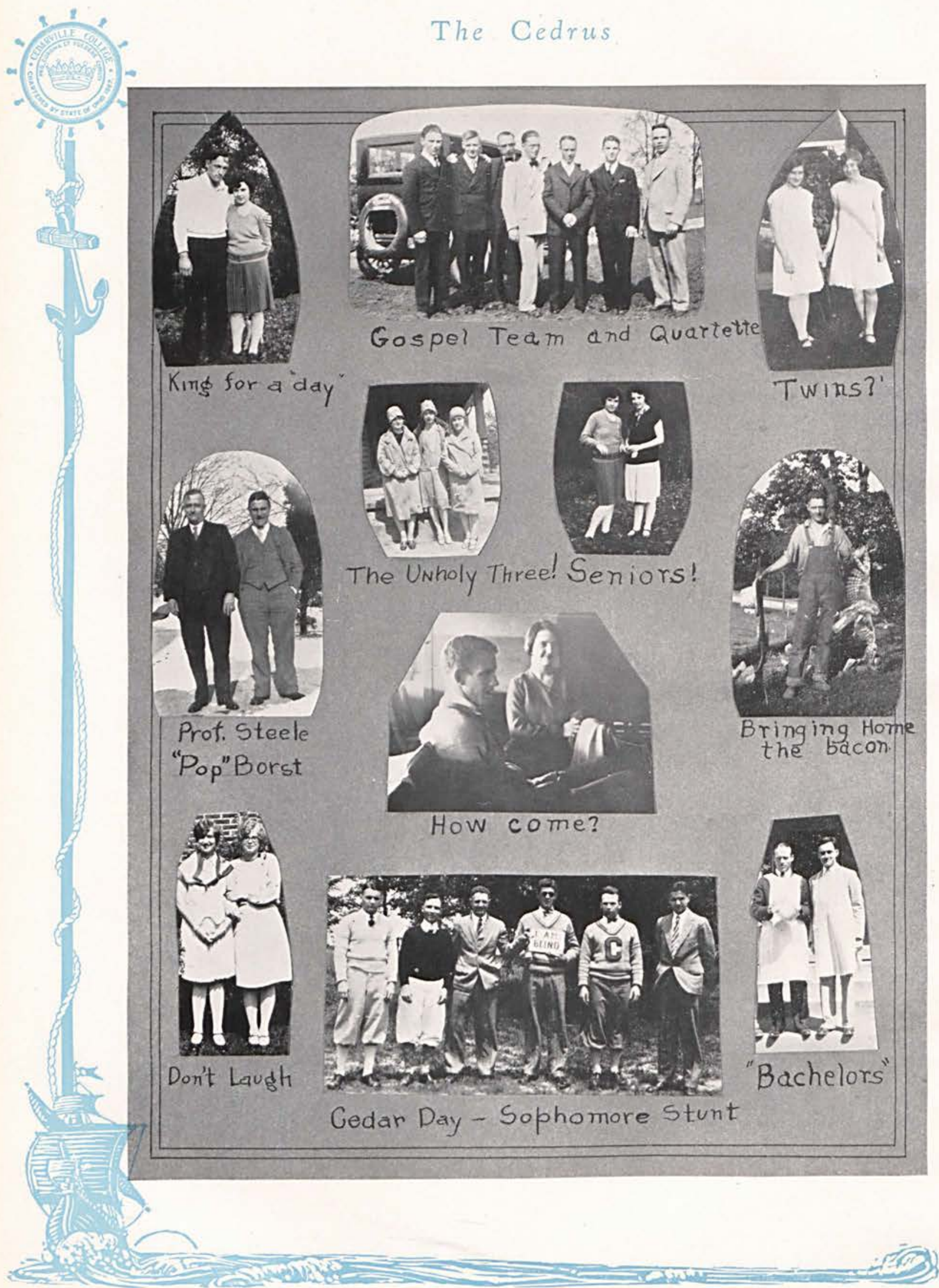

Page Fifty-six 
The Cedrus

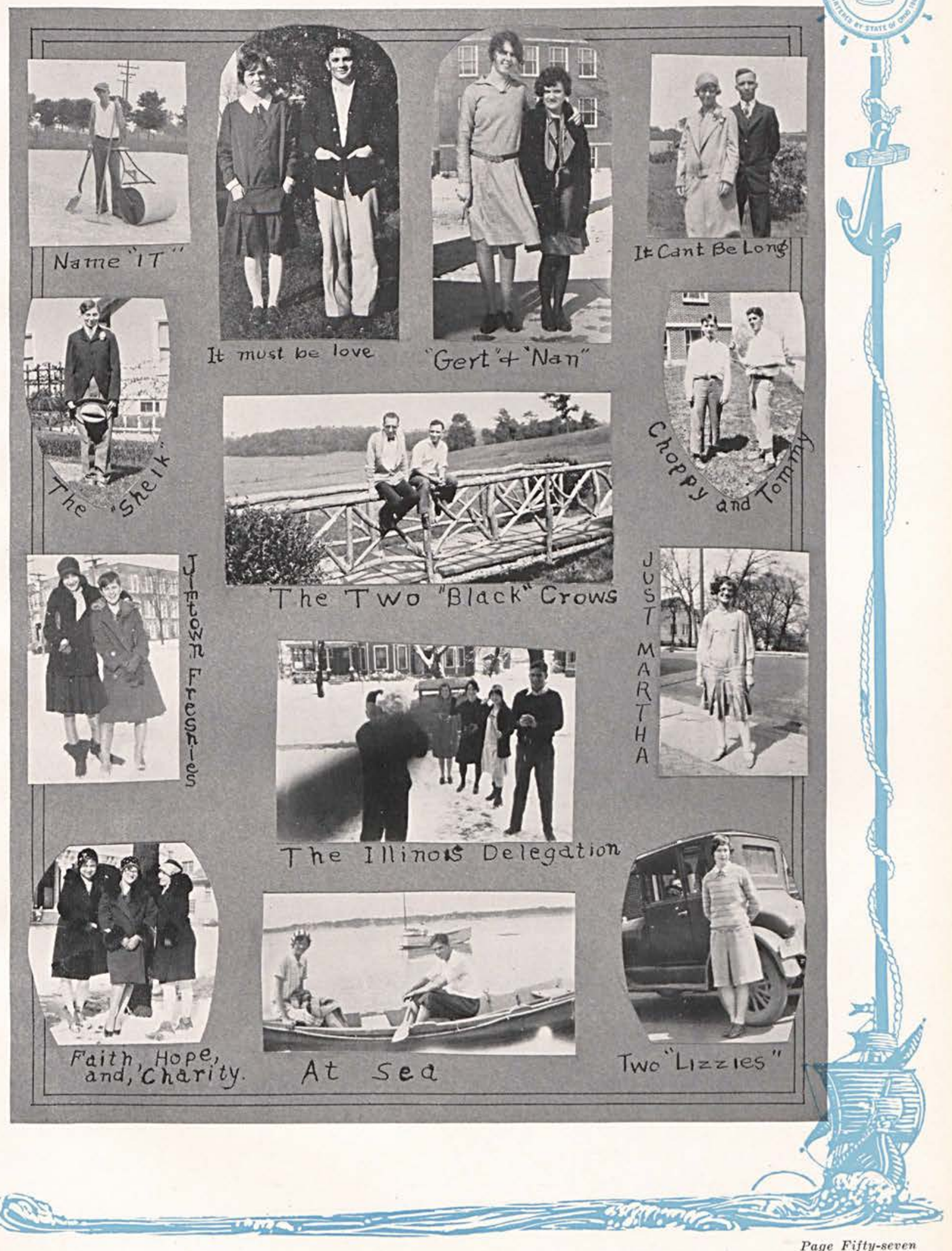




\title{
The Cedrus
}

\author{
Alma Mater \\ Cedarville's a College in a grand old state \\ Builded by the hands of her Maker great; \\ Guiding eager students thru the open gate \\ Of dear old Cedarville. \\ Fitting them for Champions of the Truth and Right, \\ Arming them completely for the coming fight, \\ Leading them to Victory over wrong and might \\ At dear old Cedarville.
}

\section{CHORUS}

Senior, Freshman, Soph and Junior, too;

Join your hearts and efforts

And in everything you do.

Onward, upward be our motto still,

Follow close the leading of

Your dear old Cedarville.

Cedarville's a College that shall ever stand,

Shedding light and glory over all the land.

Reaching out to everyone a helping hand

From dear old Cedarville.

Many are the victories that are in her way,

Many be the triumphs of the coming day.

Many be the students who shall always say,

"Our dear old Cedarville." 


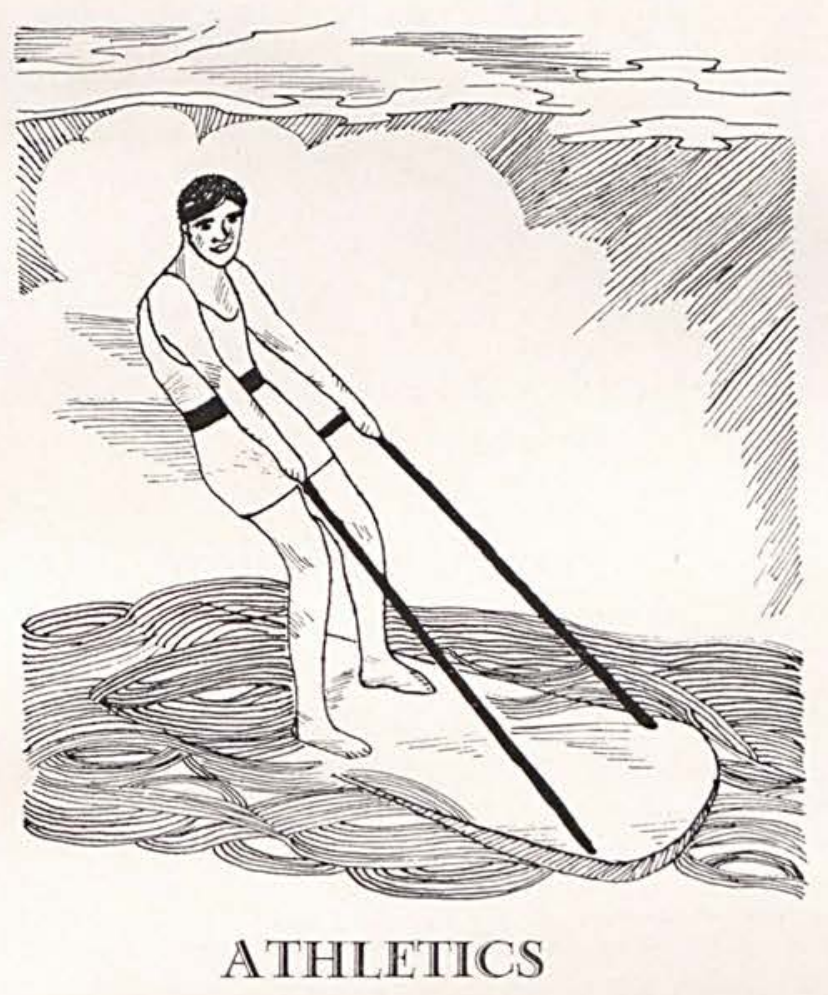





\section{The Cedrus}

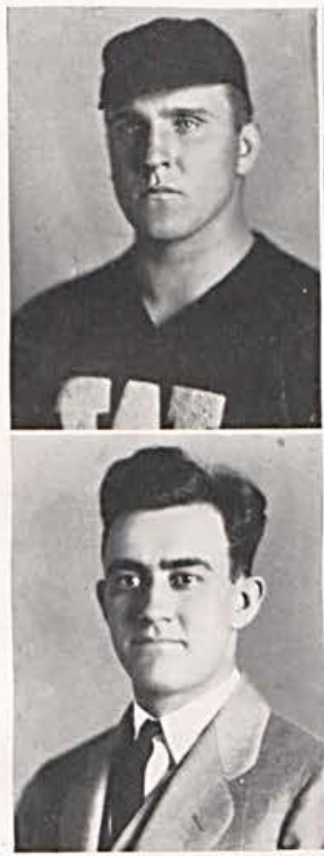

BORST BEAM

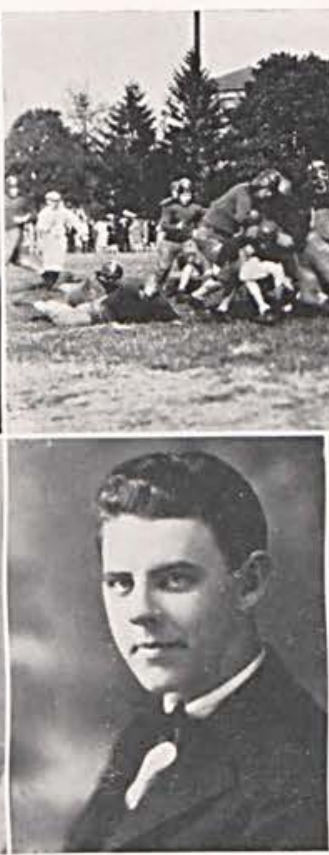

REED udis acminity

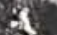

Fo-8hin: $-12$ (2)

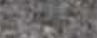

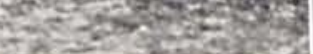

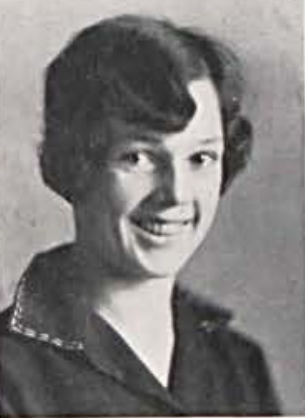

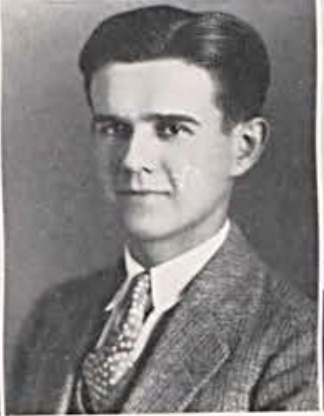

LEMON

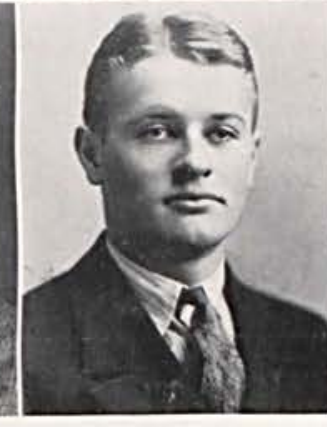

SHANNON NOR'TH

\section{Athletic Managers}

Roy Marvin Borst

Coach

Irene Shannon

Girls' Basketball

James Beam

Football

William North Assistant Football

Leo Reed Boys' Basketball

James Lemon Baseball

Perhaps few of the students, as they witness the precision and team-work of eleven men on the foctball field, the sure and swift passwork of the basketball team, or the clever plays on the baseball diamond, take time to wonder how such activities are made possible.

The secret of the cuccess of the athletic teams lies in the long hours of strenuous practice under the direction of Coach Borst. As a result of Coach Borst's faithful services, the calibre of Cedarville's athletic teams has continued to improve during the three years that he has been here.

Others who deserve much credit are the managers of the respective teams. Veterans in this important work are Irene Shannon, who has managed the girls' basketball team for three years, James Beam, who, for three years has been football manager, and James Lemon. who has managed the baseball team during the past three years. No doubt, only the Coach and the members of the teams know how faithfully these persons have labored.

William North and Leo Reed, contributions from the Freshman Class to Coach Borst's managing staff, although new at the work, managed affairs like veterans, and deserve the commendation of the student body.

C. C. F.

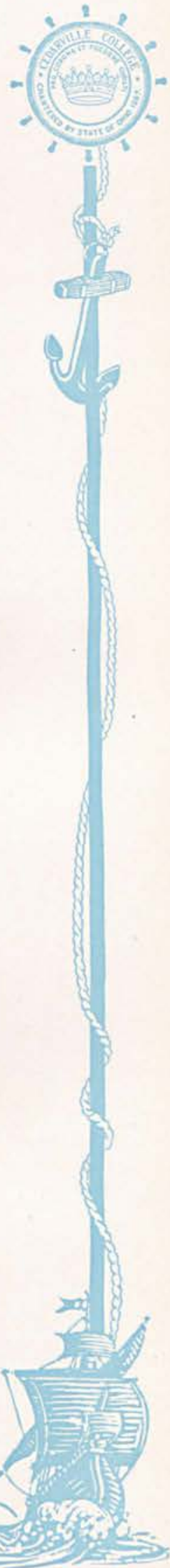

Page Sixty-one 


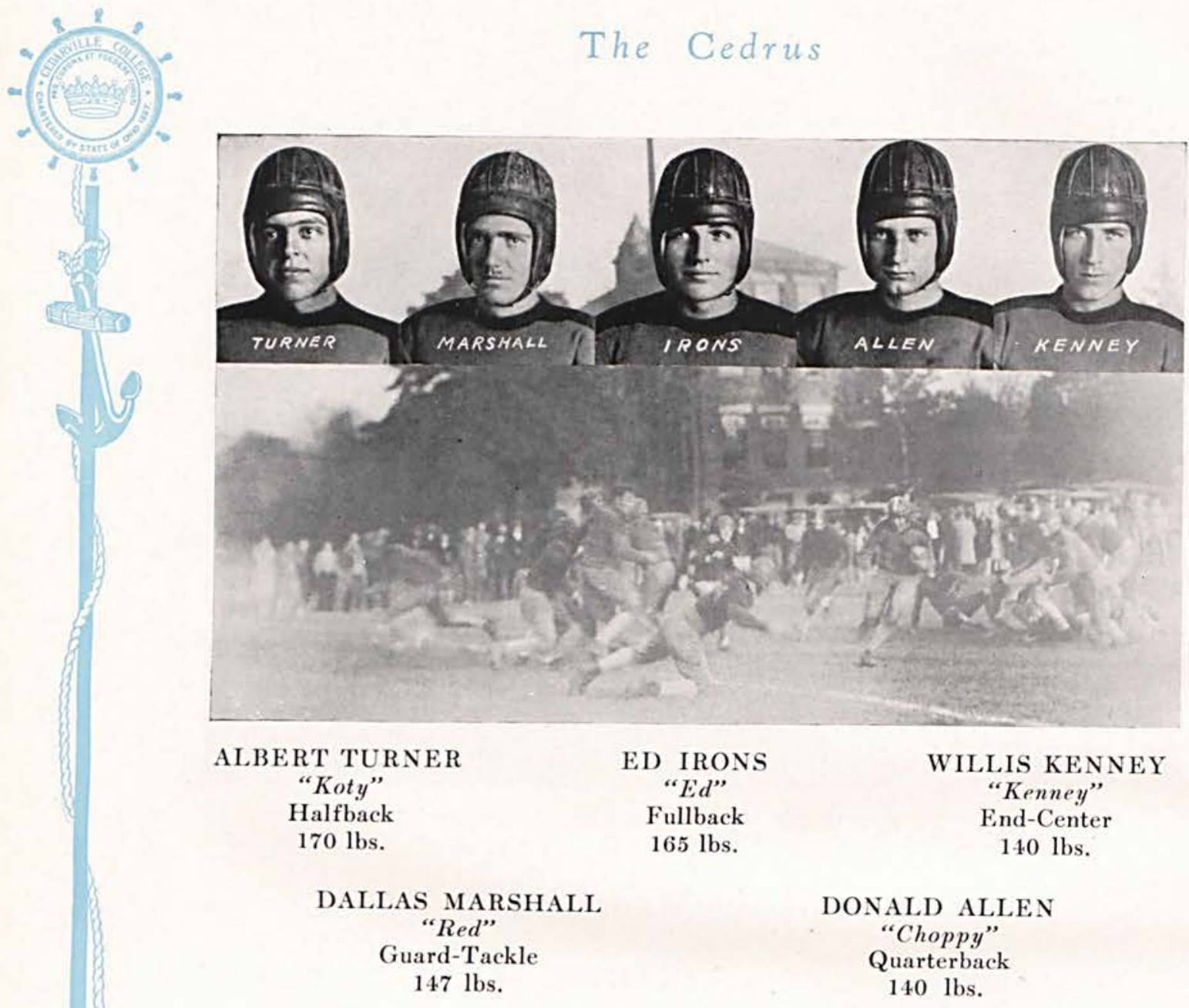

\section{Football 1928}

The small college always has a hard time when it comes to football. It must have material. Cedarville was no exception last fall. We had lost Dave Adair, our fleet half-back, and Captain Nagley, our brainy quarterback, by graduation. Several of our other regulars did not return. Consequently, the outlook was not very bright. Yet, considering the material that reported to the call, C. C. gave a very good account of herself. Coach Borst gave his best to make a football team out of a bunch of men who had never played together before. The Orange and Blue showed on several occasions what it was capable of doing after once "getting up steam." Sometimes we looked like world beaters and sometimes like a third rate high school team. Yet, as a whole, the football season was a success. Although winning only one game, the members of the squad gained a vision of clean athletics and fair play that will mean much to them in later life. For this we must give credit to Coach Borst. 


\section{The Cedrus}

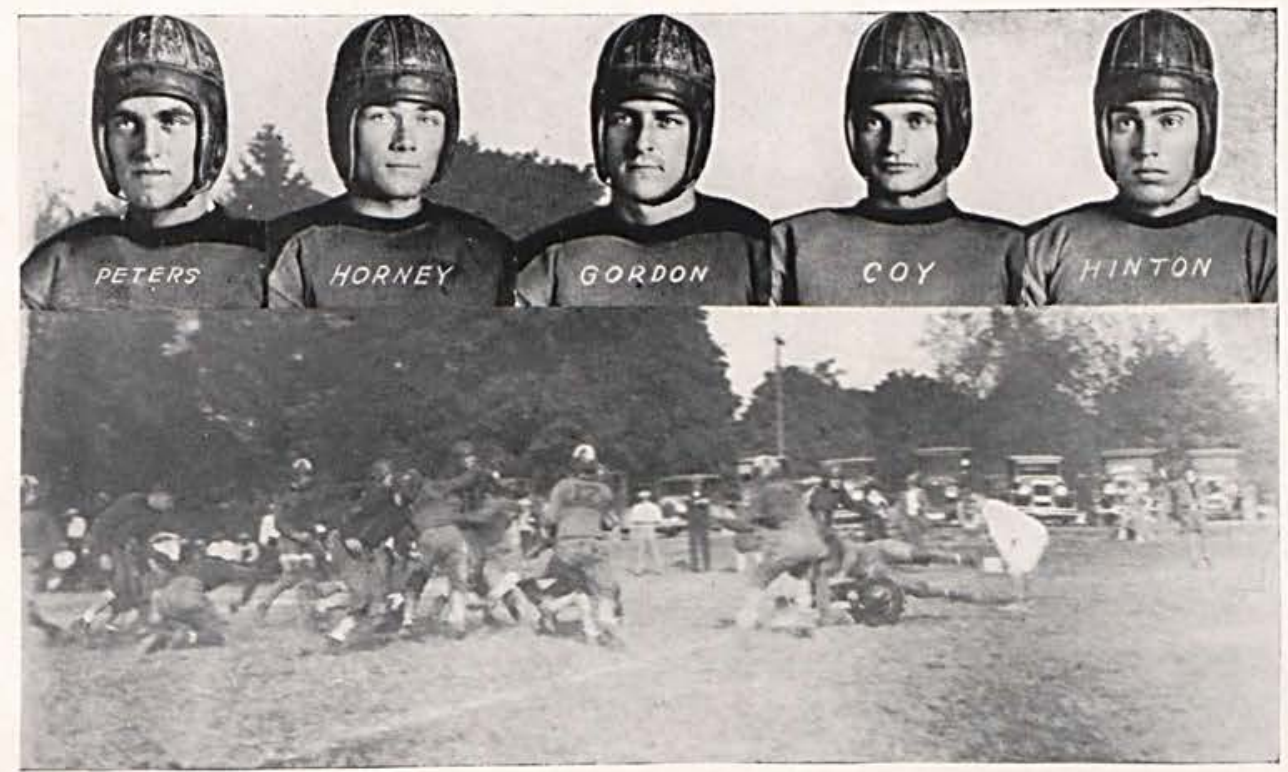

\section{OWEN PETERS \\ "Pete" \\ End \\ $155 \mathrm{lbs}$.}

\section{GEORGE GORDON \\ "Bunk" \\ Guard \\ $160 \mathrm{lbs}$.}

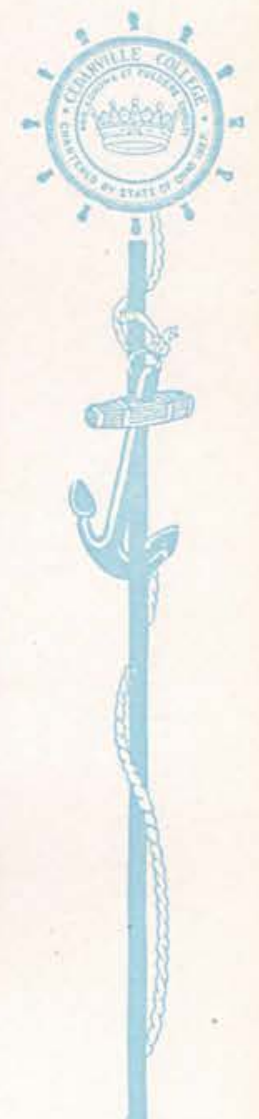

\section{ROBERT HORNEY \\ "Bob" \\ Guard \\ 148 lbs.}

\section{EDGAR HINTON "Ed" \\ Halfback \\ 165 lbs.}

\section{GLEN COY \\ "Coy" \\ Halfback \\ $155 \mathrm{lbs}$.}

The Orange and Blue opened the season September 29 playing Kentucky Wesleyan at Winchester, Kentucky. The Panthers were rated one of the best in the state, and they certainly looked as if they were capable of maintaining that reputation. The day was cloudy, and as the game began, it started to drizzle and continued to do so throughout the game. The bright spot in the game for Cedarville was Turner's run after picking up a fumble. Although the final score was 30 to 6 against us, we had made a good showing against a good team.

The next week we stacked up against our old foe, Antioch, at Antioch. Due to overconfidence and very poor football, we lost 31 to 6 . Antioch was at her best and Cedarville at her worst.

The following week hopes were revived somewhat, when Rio Grande came to Cedarville with a team of huskies. They outweighed us twenty pounds to the man, 


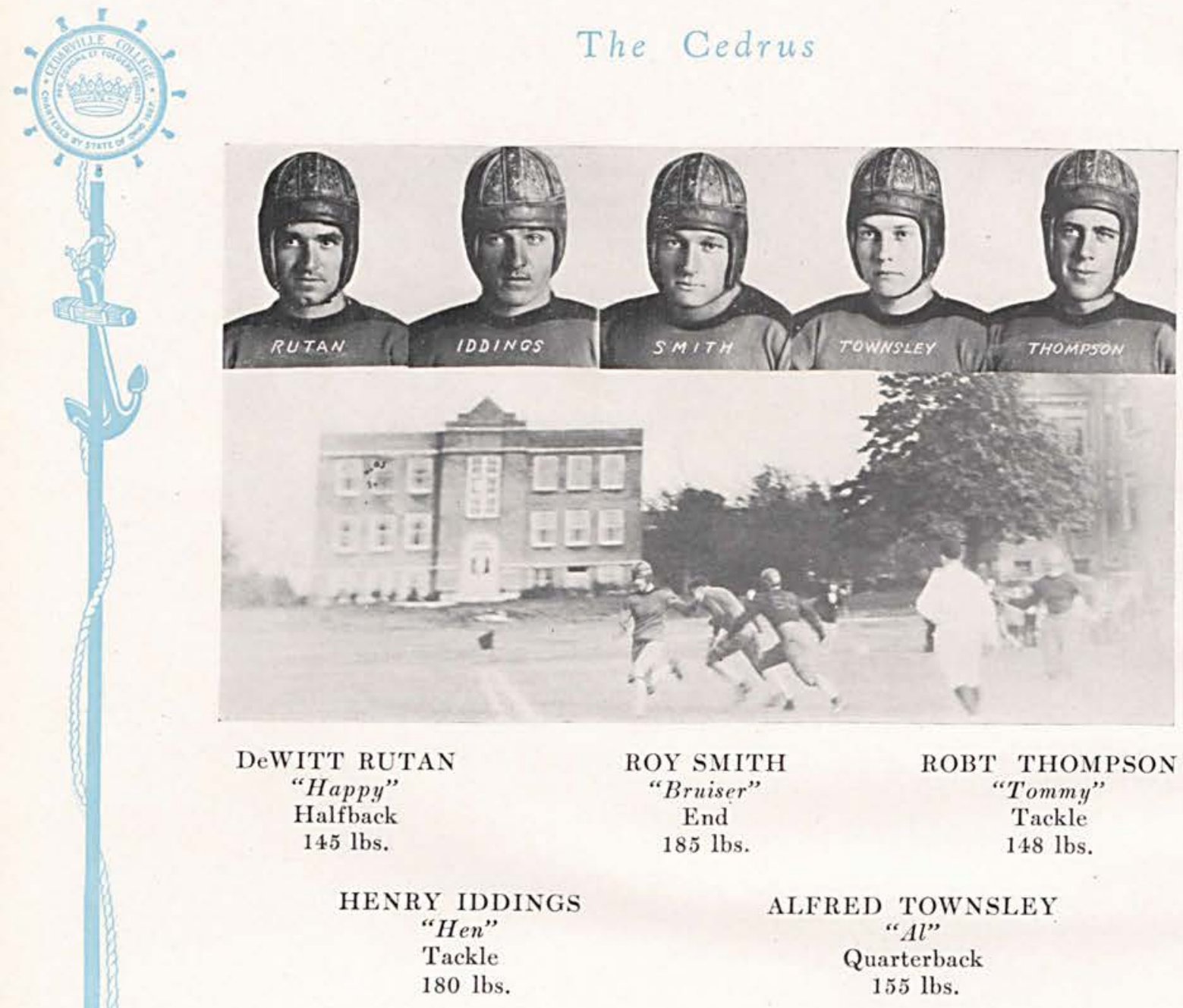

but C. C. saw that they returned home with less brawn. It was an ideal football day, and both teams played good clean football. However Rio Grande had a little better team, so they returned home with a well earned 12-0 victory.

The next week C. C. invaded the stronghold of the "Green Tornado," and as usual Cedarville returned with the short end of the score. This time it was 42-6. "Mr. Weimer and Company" were too much for the C. C.'s light team, but we had done one thing a C. C. team had not done for a long time, and that was to earn a touchdown against Wilmington. In the last quarter Rutan received a long pass from Smith for the lone marker. We were badly battered and beaten, but no one was seriously injured. Every member of the team vowed to show the "Green Tornado" on November 9th what the Yellow Jackets could do when their ire was aroused.

Page Sixty-four 


\section{The. Cedrus}

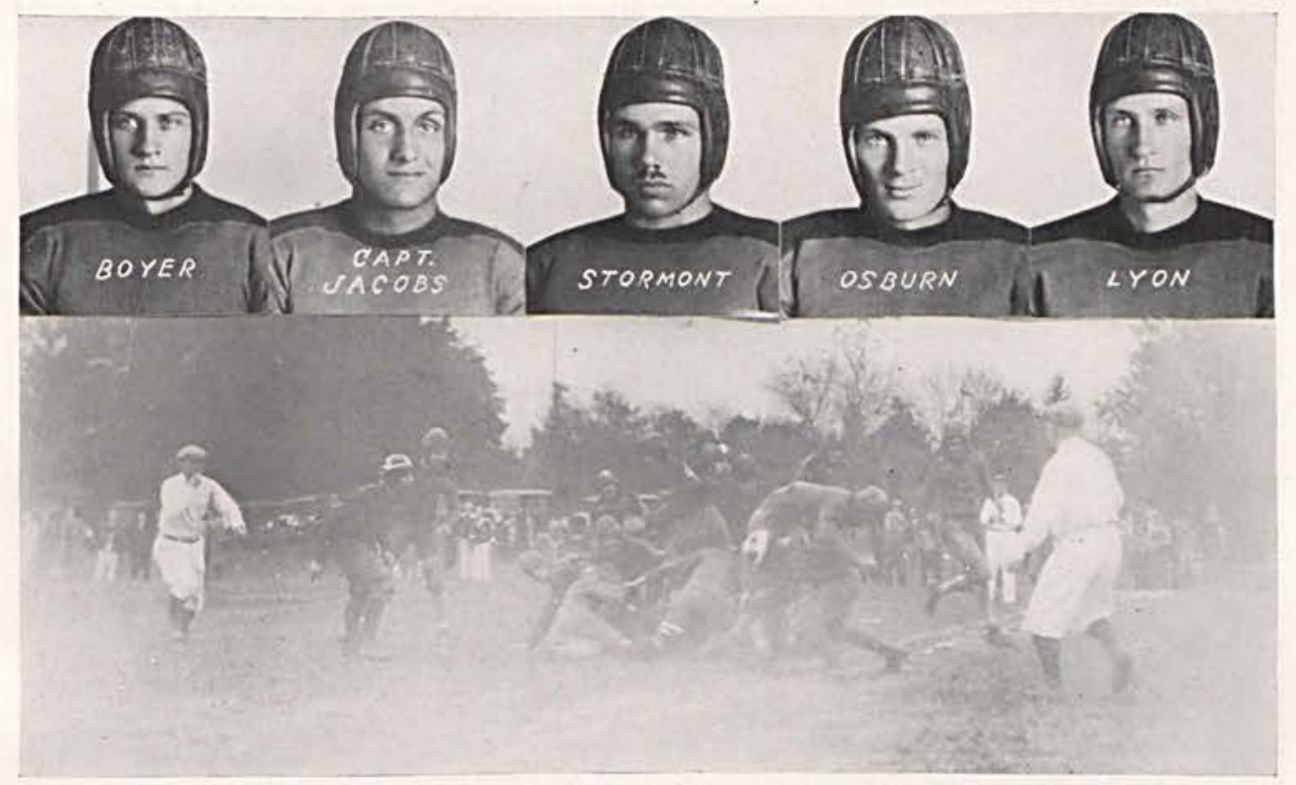

WALTER BOYER
"Boyer"
Guard
140 lbs.
JAS. STORMONT
"Jim"
Center
$158 \mathrm{lbs}$
SILVA LYON
"Silva"
End
$148 \mathrm{lbs}$.

$\begin{array}{cc}\text { ROBERT JACOBS } & \text { HAROLD OSBURN } \\ \text { "Jake" } & \text { "Red" } \\ \text { Tackle } & \text { Guard } \\ 165 \text { lbs. } & 150 \mathrm{lbs} .\end{array}$

After taking most of the next week fairly easy in order to get rid of our bumps and bruises, we journeyed to Kent State Normal. The trip was made by bus. It started to rain Saturday morning, and by afternoon it had settled down to a steady drizzle. The football field was mud-mud, three inches deep-sticky, cold, wet mud. Water one to two inches deep stood all over the field-and still it rained. However we played football. We came home on the short end of a 26-0 score. What a day! What a game! But best of all, what a trip! Let's give three cheers for Coach Borst!

After having such a lovely time at Kent, the members of the team decided to really enjoy themselves for once. We played Antioch that week, which made two reasons for having a good time. Before the game it was decided to give Antioch the short end of 50-0 score, or near that. The half ended 26-0 in our favor. We were slightly more than half way there. In the second half we let down and merely defeated them 39-0. We couldn't rub it in too much. The whole team functioned like clock-work with nearly every one sharing in the scoring. The only things to 


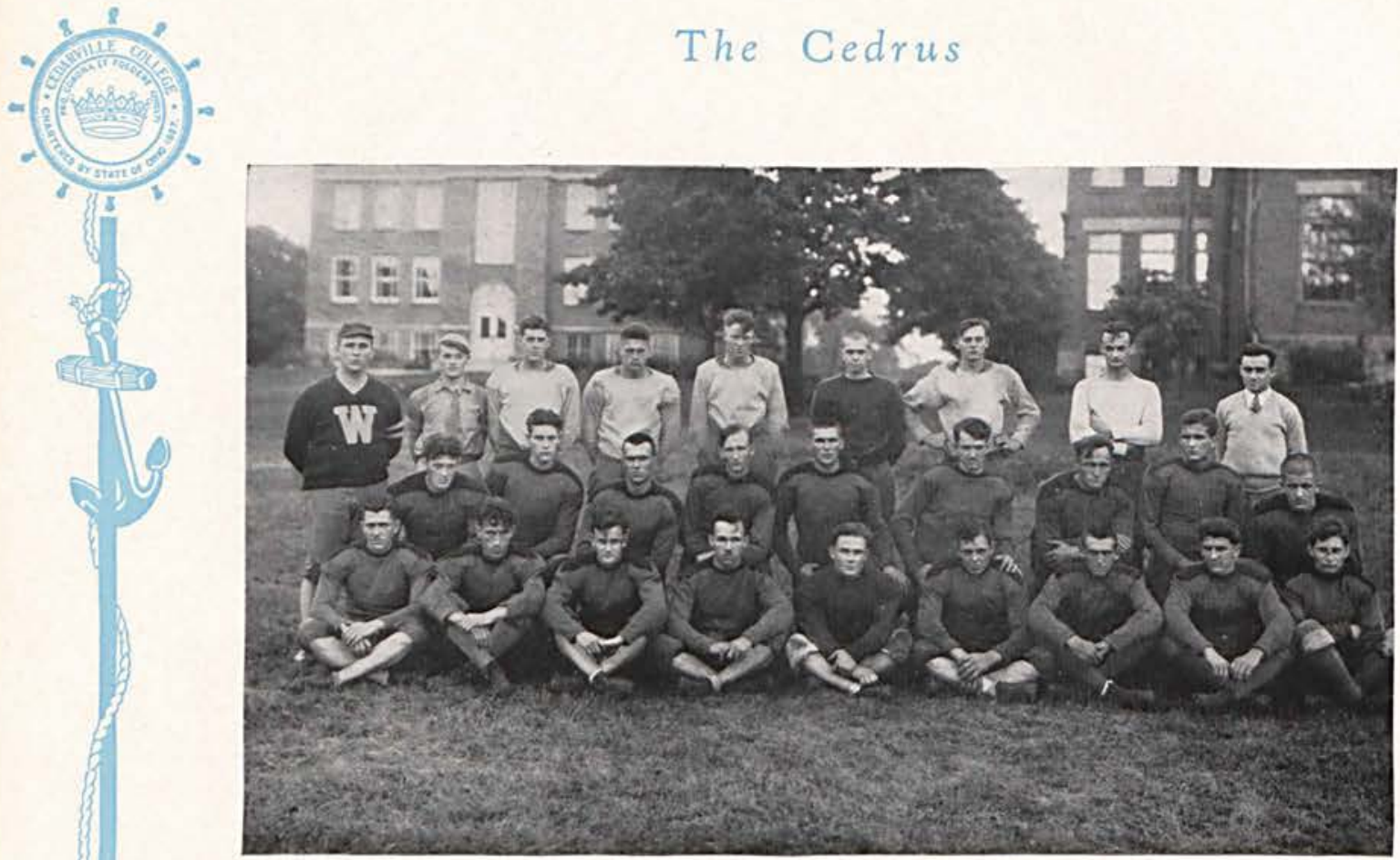

dim the glory were Walter Boyer's fractured ankle and George Gordon's broken hand.

The "Green Tornado" arrived the next week in full force, but went home with greatly diminished glory. The Yellow Jackets had found their stride. Cedarville gave Wilmington a touchdown on the first kick-off by neglecting to cover the ball. We came back strong however, and at the half the score was 20-20, and until the last three minutes of play the score remained tied. Cedarville's defense crumbled at this point, and Wilmington registered two touchdowns in quick succession, making the final score 32-20. Although we lost the game, Cedarville fans will long remember this game as the best of the 1928 season.

On November 17, C. C. ended the season at Rio Grande. Cedarville was worn out from the game with Wilmington, and furnished only the most feeble opposition to the attack of their opponents. The game ended with the score 12-0 in their favor.

We cannot say that the football season of 1928 was not a success, although we placed only one game in the winning column. A successful season is determined by the work accomplished with the amount of and kind of material with which a coach has to work. Coach Borst taught raw recruits who came out at the beginning of the season to work in harmony and to play clean, hard football.

We hope that in the future years C. C. may continue to be represented on the football field and elsewhere by men with such ideals as our Coach as kept before the men under his direction during the past season.

J. C. S. 


\section{The Cedrus}

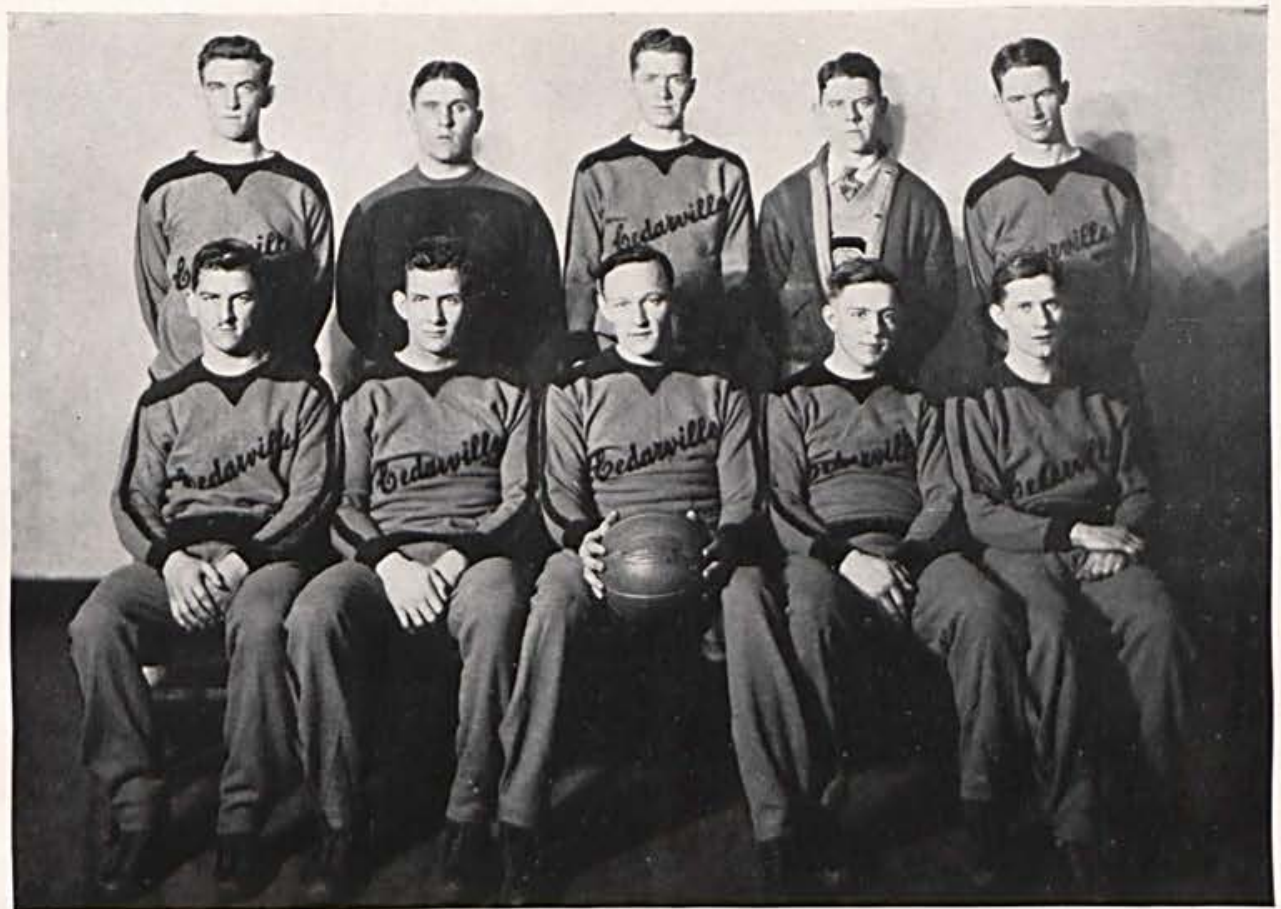

BOYS' BASKETBALL SQUAD

\section{Boys' Basketball Season 1928-1929}

The boys' basketball squad, although not winning as many games this year as last ycar's fine squad, nevertheless had a successful season considering the calibre of the opposition encountered. The loss of two of last season's regulars, David A dxir and William Nagley, left the two forward positions to be filled by new mex. As the season progressed a good passing team was developed from last year's second team and the remaining regulars. But, as is the case in most small colleges, enougb good reserve material was not available to relieve the regulars, consequently the brunt of the attack fell on five men. Yet, in spite of this handicap, the whole squad gave all they had all the time.

When the season 1928-1929 was over seven games had been won and fourteen lost. Although not up to last season's record, this year's record is one of which no college should be ashamed. With only one regular graduating, the outlook for next year is not so dark as might be. We hope that next year's team may have the success that has been allowed the two fine teams of the past seasons and bring more athletic honors to old C. C. 


\section{The Cedrus}

The season started the same as that of last year with a win over Antiochthis time to the tune of 42-25. The outlook was bright for this year's team, although critics predicted failure.

The next game C. C. invaded the stronghold of the "Green Tornado" but Mr. Weimer and cohorts were again too much for the Yellow Jackets, and we lost 37-24. But we resolved to do better when they came to Cedarville.

We played the University of Cincinnati the next game and held last year's Ohio Conference Champions to a $32-28$ score. This game was an indication of what the Yellow Jackets could do when at their best.

Meeting another strong Ohio Conference team, Muskingum, in the next game Cedarville gave their best, but lost 31-29. The score was tied four times, and there was not a time during the game when more than two or three points separated the two teams.

Very few small colleges care to meet three former Ohio Conference Champions in six days; Cedarville did that very thing. The third game was with the strong Ohio Wesleyan five, rated by critics as one of the best in the country. Our team was somewhat tired out by the hard fought Muskingum game two days before and lost an uninteresting game 52-18.

Ohio Northern felt the sting of the Yellow Jackets for the first time this year, and it left them in no playful mood. We gave them the short end of a 41-29 score and made them like it. This was C. C.'s second win of the season and the first win of 1929 .

Cedarville athletic teams nearly always have bad luck when they journey to Rio Grande. This year was no exception - as in football so in basketball. Playing on a smaller floor than usual, the Borstites lost 30-17.

Page Sixty-eight 
The Cedrus
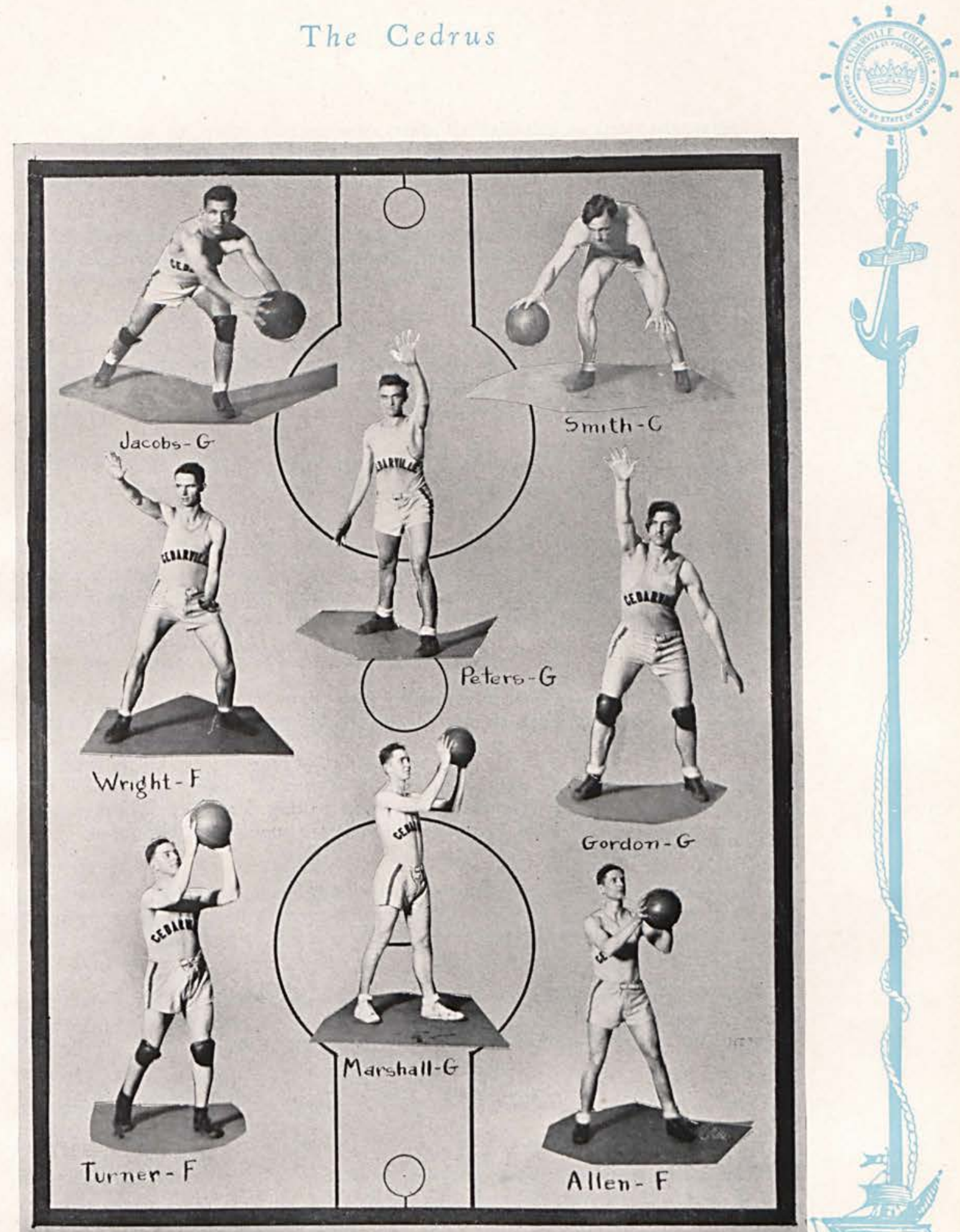

A

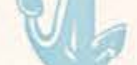


Indiana is noted as a basketball state, consequently when we lost to Hanover College on their own floor 36-27, the defeat was no disgrace. Hanover ranks among the leaders of the hardfloor game in the Hoosier state.

We met an old foe, Bliss, the next week at Columbus. Smarting under a 48-33 defeat last year, they were ready for us. Although we fought hard, trying to repeat last year's success, our efforts were in vain. We came home on the short end of a 44-21 score.

Meeting another Ohio Conference member, St. Xavier, we lost 28-12. The Irish always have a good team and this year was no exception. It was worth it to take such a score from such a foe.

However, when we lost 42-34 to Findlay the defeat did not go so well. We resolved to give them the time of their lives when they came to Cedarville.

For the last two years Cedarville has defeated Wilberforce on their own floor. Last year we won 29-28. The colored lads evidently decided before the game that this should not happen again. They carried out their intentions to the letter, so we could do nothing but come home with the score they gave us. It happened to be $34-23$.

Springfield Business College furnished fair opposition for C. C. next. They simply couldn't keep the pace we set, and had to be content with a 53-29 score.

Bliss invaded C. C. the next week with intentions of making us take the medicine they had given us at Columbus. We were waiting for them. What a game! We made them take their own dose, and did it to the tune of a 33-28 win.

Hanover furnished the next opposition. Their game here was the first of a trip for them. We hated to make their trip a success, although wishing them the best of luck; so proceeded to defeat them $32-31$ in a fast and furious game.

Then we met Antioch there for the second game with our old rivals. Last year we defeated them twice in every sport. But they were determined things should be evened up this year, so they sent us home with a 34-31 defeat.

Rio Grande simply couldn't be stopped here, and we lost our second game to them by a 34-24 score.

Springfield Business College, smarting under their earlier defeat at Cedarville, gave us better opposition at the Y. M. C. A. court in Springfield than had been expected. We had a hard time winning, but finally put the game on the right side of the column by a score of $37-35$. 


\section{The Cedrus}

In the next game Wilmington defeated us on our home court 35-25. We were leading at the end of the first half $17-16$ but were unable to keep the pace the "Green Tornado" set the second half.

Findlay came to C. C. for their second game, determined to show us some real basketball. As we had given them one game this season, we didn't like to lose two to the same college. But they felt differently, and we lost the game 48-38.

Finally the last game of the season rolled around. It was fitting that we should have some old rival play us in this, the final game. Wilberforce came here on a dark and dismal night. We sent them home in a dark and dismal mood. We just had to win the last game and close a season that had been fairly successful. After the battle smoke had cleared away, we found we had won 35-29.

So closed the 1928-1929 season of basketball at C. C.

Opp. C. C.

Opp. C. C.

$\begin{array}{lll}\text { Antioch _. } & 25 & 42 \\ \text { Wilmington } & 37 & 24 \\ \text { U. of C. } & 32 & 28 \\ \text { Muskingum } & 31 & 29 \\ \text { Ohio Wesleyan } & 52 & 18 \\ \text { Ohio Northern } & 29 & 41 \\ \text { Rio Grande } & 30 & 17 \\ \text { Hanover } & 36 & 27 \\ \text { Bliss _. } & 44 & 21 \\ \text { St. Xavier } & 28 & 12\end{array}$

Findlay

Wilberforce

34

24

Springfield Business College 29

Bliss 28

Hanover

31

Antioch 34

Rio Grande ㄴ.. 34

Springfield Business College 35

Wilmington 35

Findlay 48

Wilberforce 29

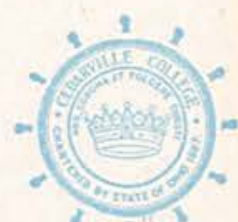

$\gamma \frac{1}{1}$

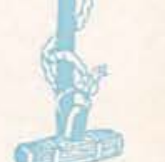




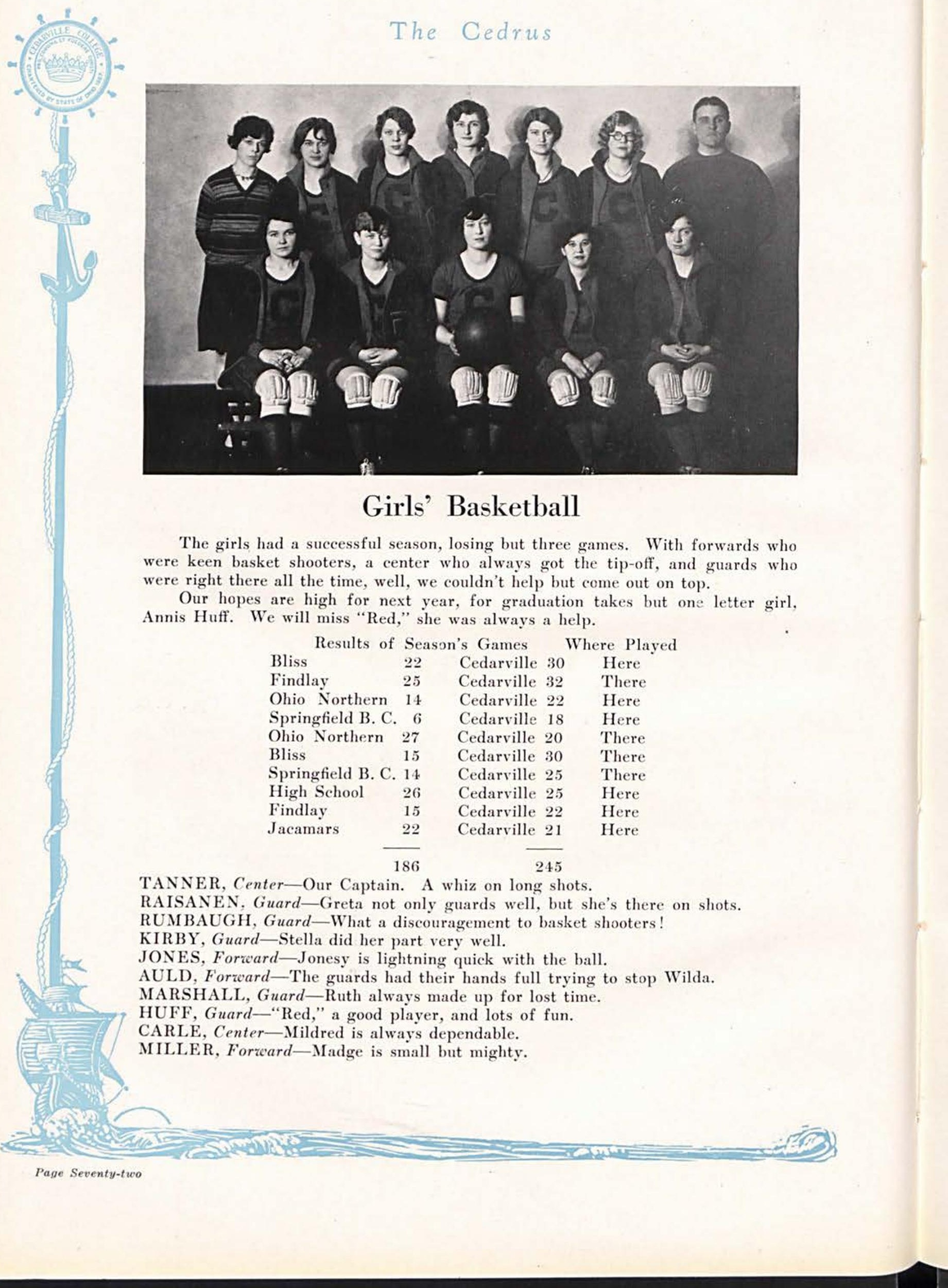


The Cedrus
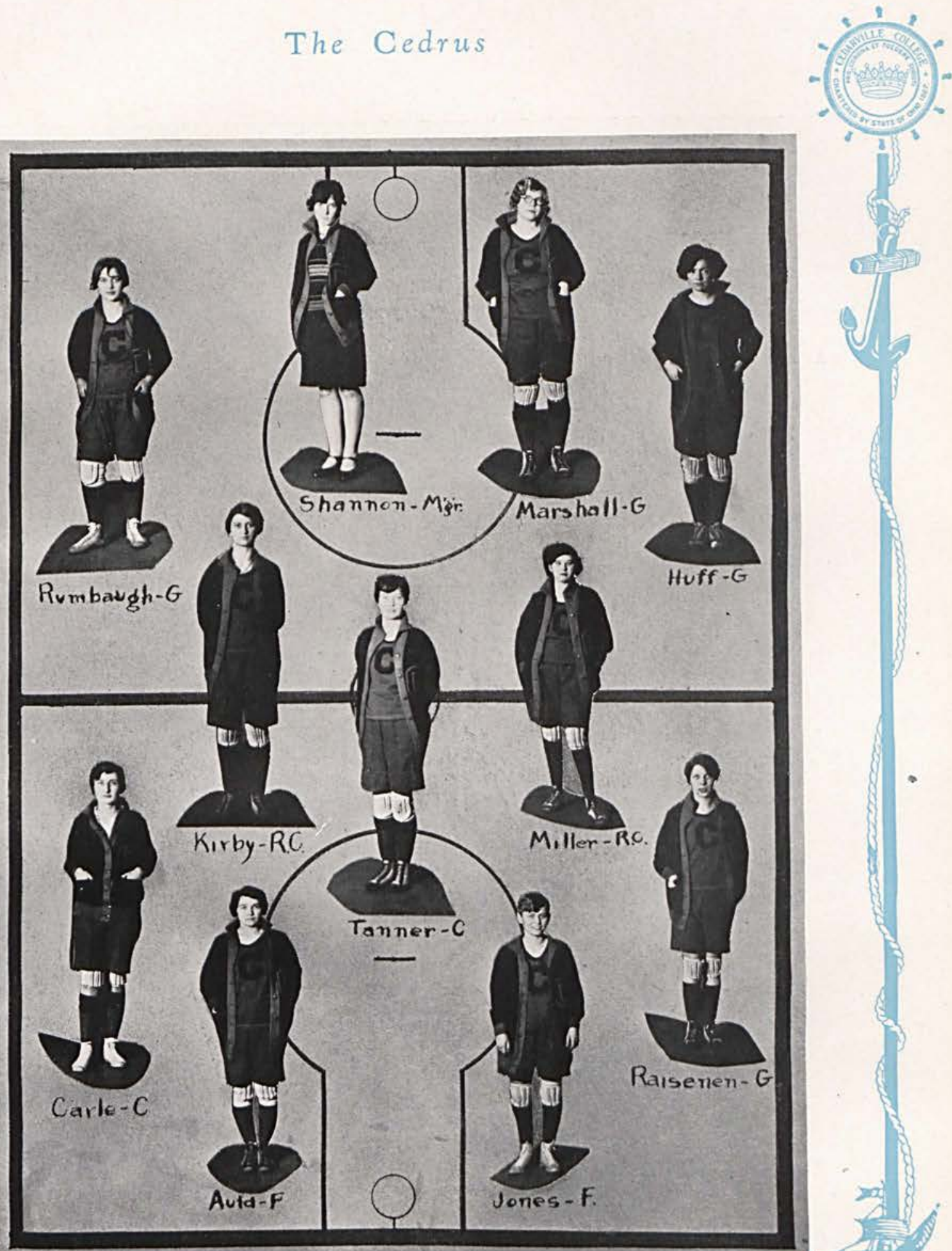


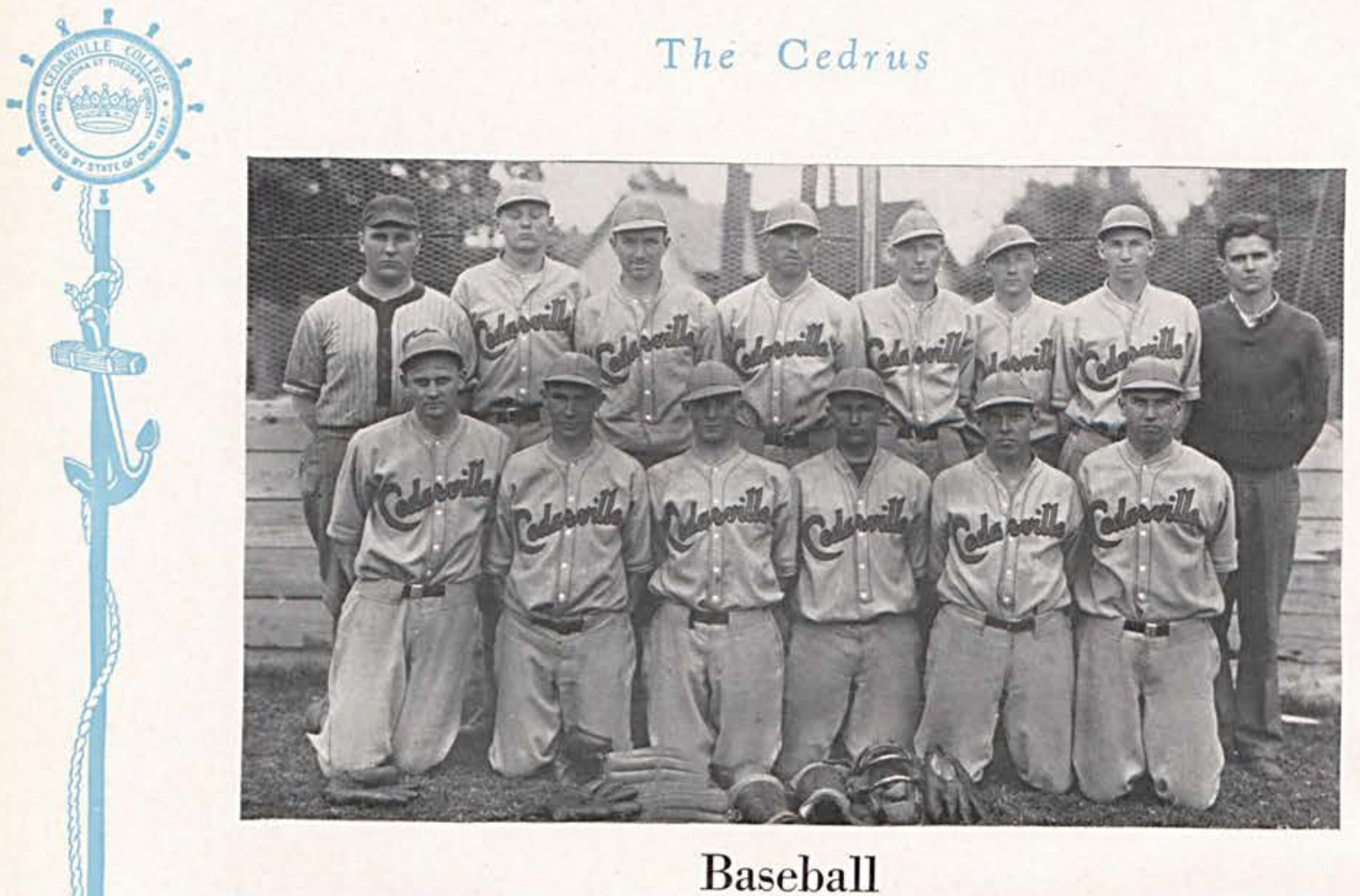

The Cedarville College baseball team, after a rather slow start in the spring of 1928, hit its stride after playing a few games, and succeeded in making it the most successful baseball season that Cedarville had experienced for several years. Although a majority of the games were lost, several were decided by very close scores, and the final inning always found the team fighting until the last man was out.

The veterans from the previous year were: Nagley, Adair, Tanner, Armstrong, C. Lyon and Gibson. Cedarville was fortunate in having several promising freshmen, among whom were: S. Lyon, outfielder; Morton and Rutan, catchers; A. Turner, pitcher and first baseman; B. Turner, pitcher and outfielder; Smith, first baseman; Fisher, third baseman; Duffy, utility man.

Nagley's pitching was one of the bright spots of the season. The little southpaw defeated Antioch twice, and Muskingum once. He lost a hard fought teninning battle to Wilberforce, and a close game to the state championship Dayton U. team.

Adair was a consistent hitter throughout the season, and due to his versatile playing ability was shifted about the diamond quite a bit.

Tanner started the season in the outfield, but was shifted to shortstop position after the first game, when it became apparent that the team was seriously weak at that place. Considering his inexperience in the infield, he did remarkably well in that most difficult of positions, and was recognized as one of the surest hitters on the team.

Armstrong played his usual reliable game in the outfield, and made a fair record with the bat.

A. Turner was the most sensational player developed during the year. Besides playing excellent games at first base and behind the bat, this freshman pitched a game against Wilmington that caused the fans to regard him as Cedarville's next star hurler. 


\section{The Cedrus}

The season opened with a defeat at the hands of Wittenberg, due chiefly to the weakness of a green infield and insufficient practice.

In the second game Cedarville lost a slugging contest to Wilberforce.

The third game resulted in a victory for Cedarville over Antioch. The Orange and Blue lads were trailing in the 8 th inning 8 to 3 . However, they scored ten runs in the 9 th, making the score 15 to 8 . Nagley pitched a good game.

Wilberforce was again the victor by a score of 10 to 8 .

The next contest was with Cedarville's most ancient rivals, Wilmington. Cedarville obtained an early lead, and it looked as if the jinx was to be broken, until in the 8th Adair weakened and the Green Tornado rallied, to win 13 to 10.

May 12th, Cedarville journeyed to Dayton to take on the state champs. Nagley pitched one of the best games of his career, but hard luck and lack of support in the pinches lost the game 7 to 2 .

A few days later, Nagley again pitched superb ball. By this time the entire team was playing a good brand of ball, but Wilberforce again proved too strong, and won in the tenth, 6 to 5 .

Cedarville opened athletic relations with Muskingum College, May 26th, by defeating them 7 to 5 . Nagley was again on the mound. Fisher did his part in this game by knocking a home-run over the left field fence.

When Cedarville went to Wilmington, A. Turner started his second game of the season. Up to the beginning of the 9th inning, Turner had allowed only one scratch hit, and the score stood 4 to 0 in favor of Cedarville. But, again Wilmington rallied, and the inning ended in a tie, after Smith had knocked a home-run with two men on bases. Weimer scored the winning run in the 10th inning. Final score: Wilmington 5, Cedarville 4.

Cedarville closed the season triumphantly, May 31st, by defeating Antioch 5 to 3 . Nagley was again on the mound and pitched a masterful game. The team played well in the field and hit in the pinches, although several of the regulars were missing from the line-up. This was the last collegiate contest in which Nagley, Gibson, and Adair were to struggle for the supremacy of the Orange and Blue. 


\section{The Cedrus}

\section{OU'TLOOK FOR 1929}

As the days continue to become longer and warmer, the prospects of a winning baseball team this spring becomes brighter.

Letter men available for the team are: Rutan, catcher; Smith, first base; Tanner, short itop; S. Lycn, Walter Boyer, and Armstrong, outfielders.

This shows that the places of several of last year's regulars must be filled by new men. The catching department may not be as strong as it was last year, but Rutan and Wendell Boyer should be able to handle the receiving problem.

The pitching prospects look good, with A. Turner probably carrying the brunt of the burden, and Coy and B. Turner helping out.

At this time the infield looks very uncertain with only Tanner and Smith sure of regular positions. Among the new men who look as if they might receive regular berths are Hinton, first base or outfield; Wade Turner, who locks as if he might solve Coach Borst's problem at second, and Allen, who will try for an infield position.

Other promising players out for the team are Collins, Rowsey, Frazier, Roseberry and Scott.

The outfield, featuring S. Lyon, Walter Boyer and Armstrong, will probably be the same as last year, unless Boyer's ankle froves too weak to stand the strain.

A schedule of 15 games has been prepared. Nine of these will be played in the new C. A. W. W. League-three games with each of the following: Antioch, Wilmington, and Wilberforce. Besides, two games will be played with Dayton and Wittenberg, and one with Muskingum and Defiance. 


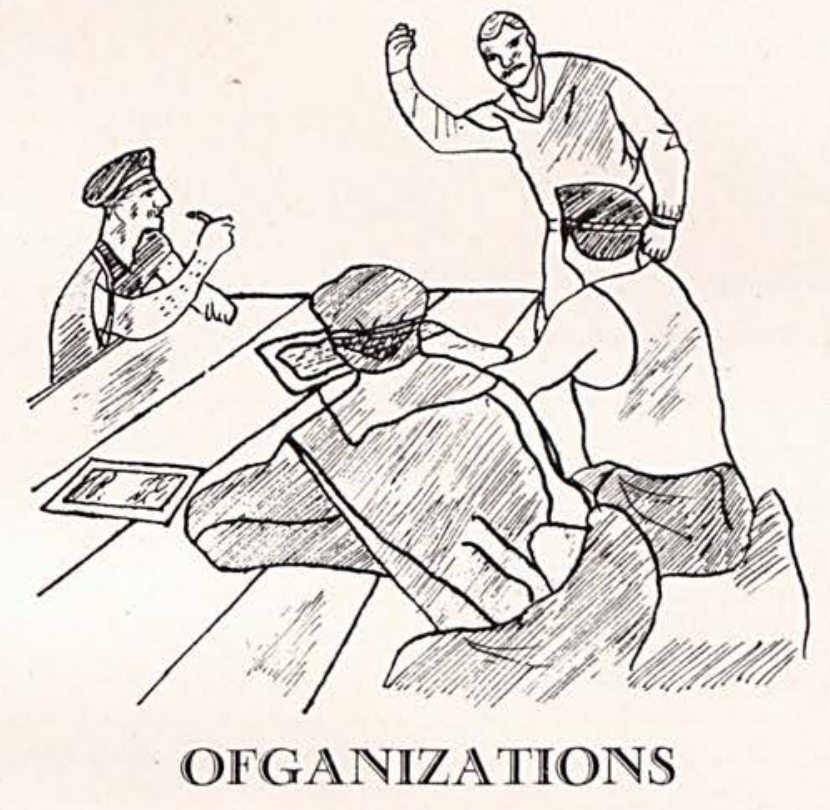





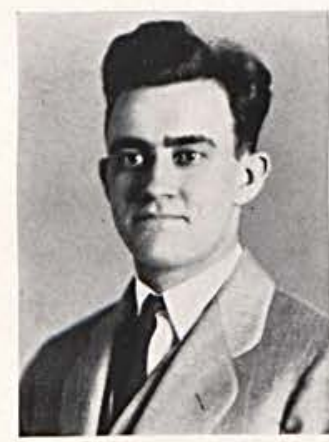

BEAM

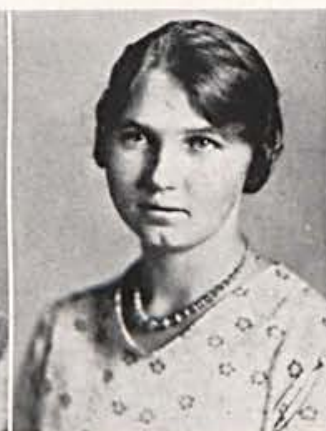

WIGAL

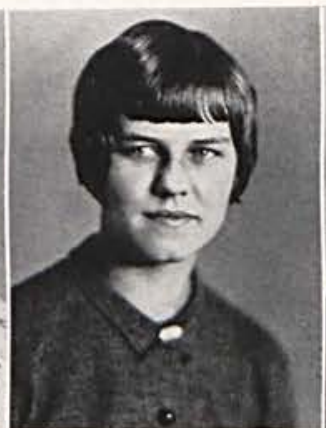

CURRY

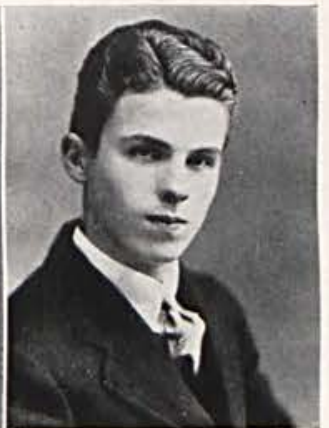

CRESWELL

\section{Student Body}

James Beam

President

Edith Wigal

Secretary-Treasurer

Wilma Curry

Cheer Leader

Nelson Creswell

Cheer Leader

Let us introduce you to the student body of Cedarville College. You will profit by making their acquaintance. They are real young men and women. We challenge you to place them beside any other student body because we are sure they will measure up, even though they are small in number. The students come from various sections of the United States, but at Cedarville Coliege they have similar interests and aims, and an Alma Mater beloved by all. You can place your trust and confidence in the student body of Cedarville; you can depend upon them. They have high ideals and their efforts are bent toward attaining those ideals.

Yet even if the students are similar in many respects, they do not lose their individuality. There are those who attain high scholastic standing; there are those who excel in athletics; there are social leaders; there are those who by their ability in public speaking, command the attention of any audience before which they appear. Music lovers have their share in the student body. There are also some who joyfully prepare to heal the tired, broken hearts of the world. At Cedarville College each of these various phases of a student's life receives its proper share of the time, interest and support of the student body.

You may ask, "But do they have pep?" We answer by an invitation to witness one of the pep meetings. No one ever gets lonesome at Cedarville (not even the Freshmen) because there is a spirit of friendliness, brotherhood and loyalty among all the students. What ever the rank every one is planning to eventually set sail upon the sea of life. There will be some smooth sailing, and some overwhelming waves. The students of Cedarville College are representative of the best young people of today, equipped with indomitable faith and courage to help them over the waves. Under the careful guidance and instruction of the members of the Faculty, who are the best in the world, these young men and women are preparing to optimistically assume the full burden of the responsibilities of tomorrow.

E. W. '29. 


\section{The Cedrus}
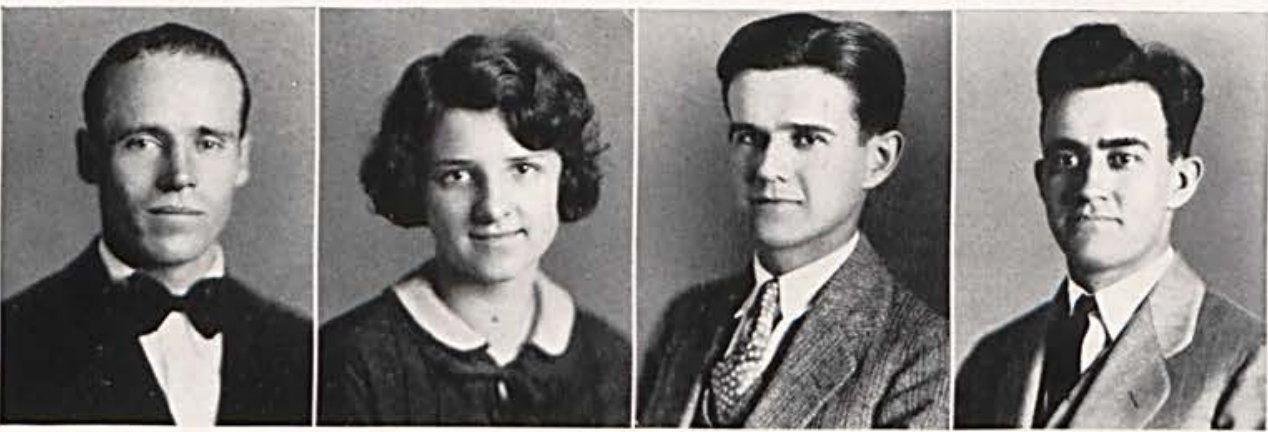

\section{Cedrus Staff}

Carl C. Frazier

Editor-in-Chief

Margaret Chandler

Assistant Editor

James A. Lemon.

Business Manager

Prof. F. A. Jurkat Faculty Advisor

James Beam

Jean Morton Advertising Manager

Robert Thompson

Greer McCallister

Alberta Snyder Artist

Lorna Leach Assistant Artist
Snapshot Editor

Frances McChesney

Silva Lyon

Mary Ruth Wham

Irene Shannon

James Stormont

Assistant Advertising Manager Snapshot Editor Society Editor Humor Editor Music Editor Athletic Editor Athletic Editor

Another page in the history of Cedarville College is almost completed, and another Cedrus Staff, after months of arduous yet willing toil, presents to the student body the result of its efforts.

The problems of the staff have been trying. With the exception of four members, the staff was entirely inexperienced. The first problem presented to this inexperienced body of students was that of planning an annual, worthy of Cedarville College, which might be published at a figure quite reduced from that expended in the recently past years. Realizing that such a task could be accomplished only through the utmost co-operation of the editorial and financial departments, the staff earnestly began work last spring. 

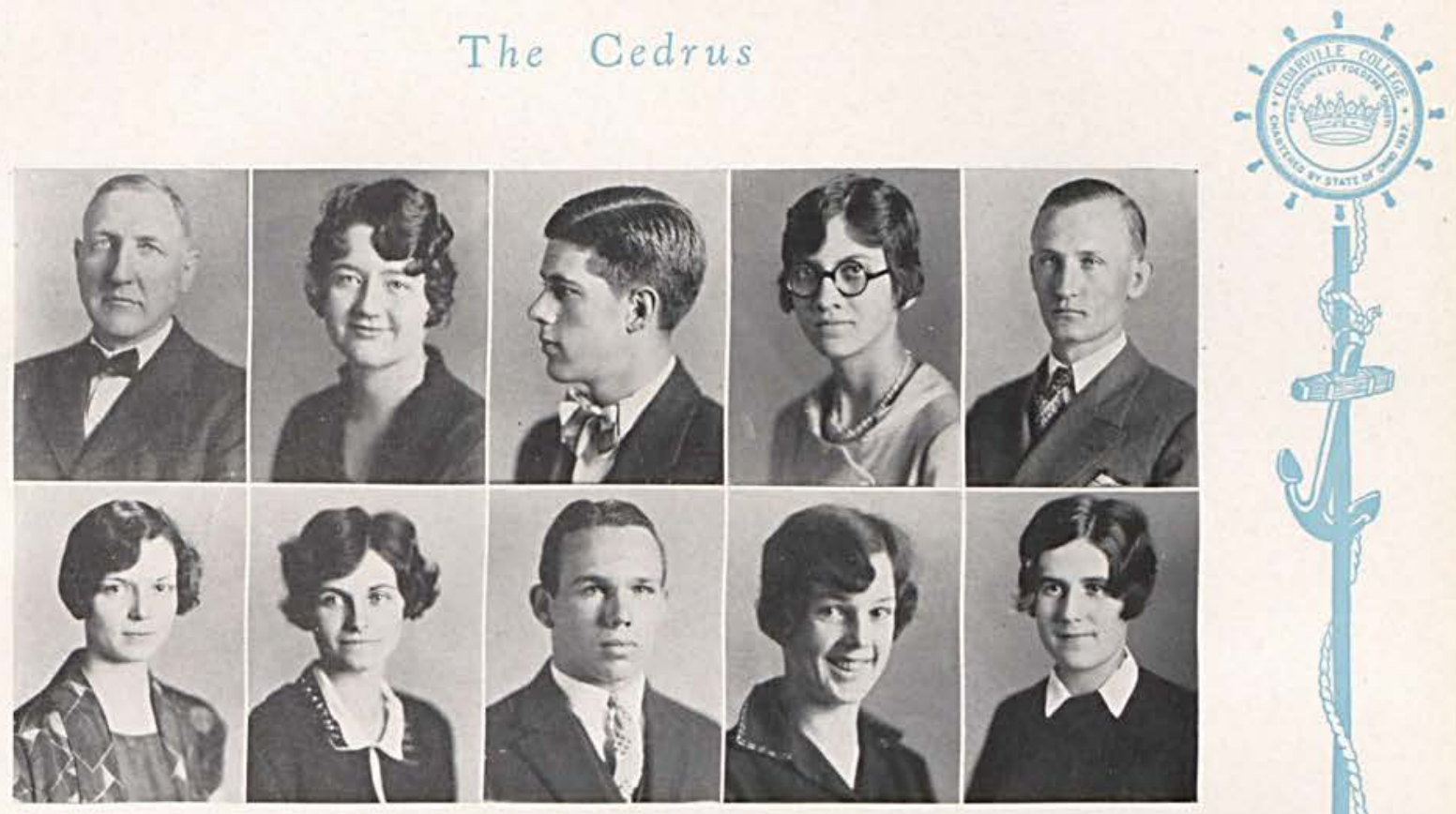

After many, many hours of strenuous work, yet work that has been both pleasant and profitable, the staff has completed its task. It believes it has succeeded in solving the big problems, and that an annual worthy of our Alma Mater has been published at a cost not too great for the size of the college. However, knowledge gained by experience of the past year now reveals to us mistakes that might have been avoided.

Thus, as we present for your approval "The Cedrus" of 1929, we hope that you will rejoice with us wherein we have succeeded - that you will bear with us wherein we have erred.

To Professor F. A. Jurkat, our faculty advisor, for his efficient supervision and kindly advice; to Mrs. Eleanor McCulla, Cleveland, Ohio, for her friendly interest and her contributions of the theme and art work, and to Mr. Elmer Jurkat, for his art and literary contributions, we are very grateful, and wish to express our sincere appreciation. We wish to thank also other members of the faculty and members of the student body for various contributions, suggestions and words of encouragement that have helped in the compiling of this book.

We, of The Cedrus Staff, have felt very keenly our responsibility to both the students and our Alma Mater. But, we have considered this responsibility a joy and a privilege.

We hope that in the future, when time and duty has scattered this student body throughout the land, we may by turning these pages return in memories to Cedarville College and live again the happy days of our college experience.

THE EDITOR. 


\section{The Cedrus}

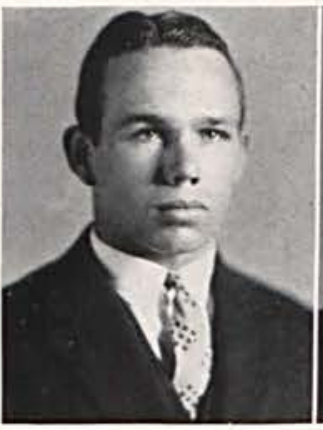

STORMONT

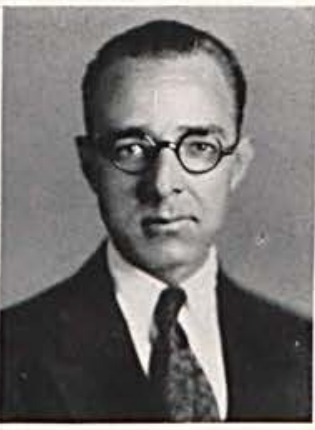

MeNEEL

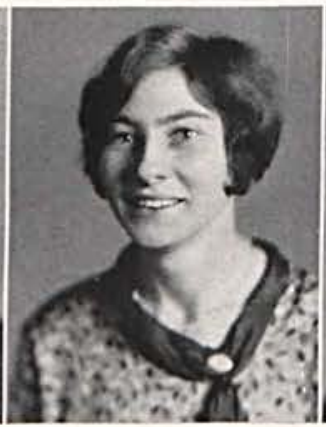

VAN PELT

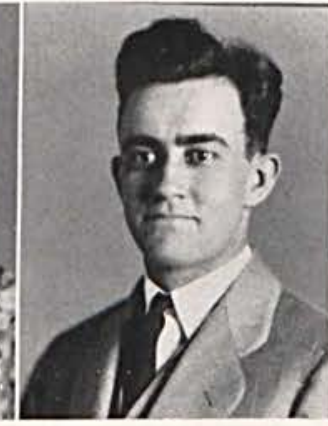

BEAM

\section{Philosophic Literary Society}

James Stormont President

Clair McNeel Vice-President

Kathryn Van Pelt Secretary

James Beam Treasurer

Frank Graham Chaplin

Paul Tanner Sergeant-at-Arms

In the years gone by some one had the vision of a Literary Society to fill the social needs of the College, so the Philosophic Literary Society was organized with the motto, "Be Perpetual Always," and perpetual it has been. Today it is the key note of the social life of the College.

It is our literary society where the true social spirit of C. C. has been expressed, the enthusiasm, the team work, the real comradeship that exists in the College.

Page Eighty-two 


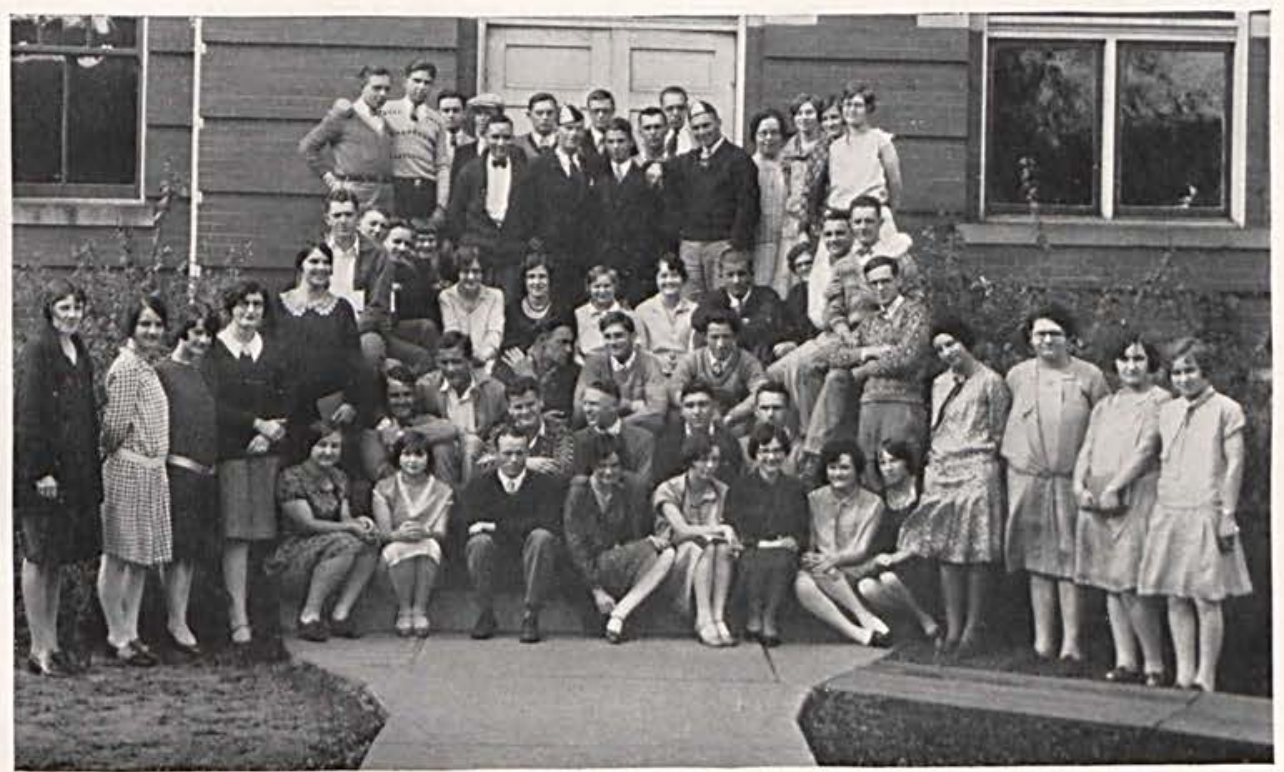

What pep, what vim has been shown in our meetings! We have never had a meeting but what some good was derived along with the pleasure. We always have fine programs, every one taking part. One entire program was prepared impromptu to test the wits of the members and we found that there was none lacking. We always open our meetings with a short period for devotions, with the reading of the Bible, prayer and songs; after this our business is transacted, the roll is called and the minutes read; then comes our program consisting of: readings, songs, piano solos and duets, current events, papers on present day topics, joke papers, personal observations and personal experiences, origin and history of important days whose dates fall near our fortnightly meetings, special program for Thanksgiving, Christmas and April Fools day. In the near future we are going to give the play, "Say It With Taffy," also we are going to have a Literary and Musical contest.

And after all is said and done, may we eat? We have all enjoyed the feeds not only for what we had to eat but for those associations which will always be dear to us after the details of college life have been forgotten.

As the years roll on may others eatch that vision of our Literary Society to bring honor and glory to old C. C.

H. E. H.

\section{OFFICERS FOR SECOND SEMESTER}

Frank L. Graham. President

Paul Tanner. Vice-President

Lillias Ford Secretary

James Beam Treasurer

Clair V. MeNeel Chaplain

Paul Armstrong. Sergeant-at-Arms

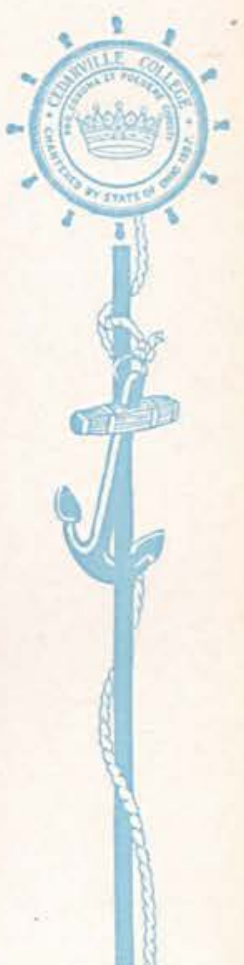

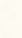




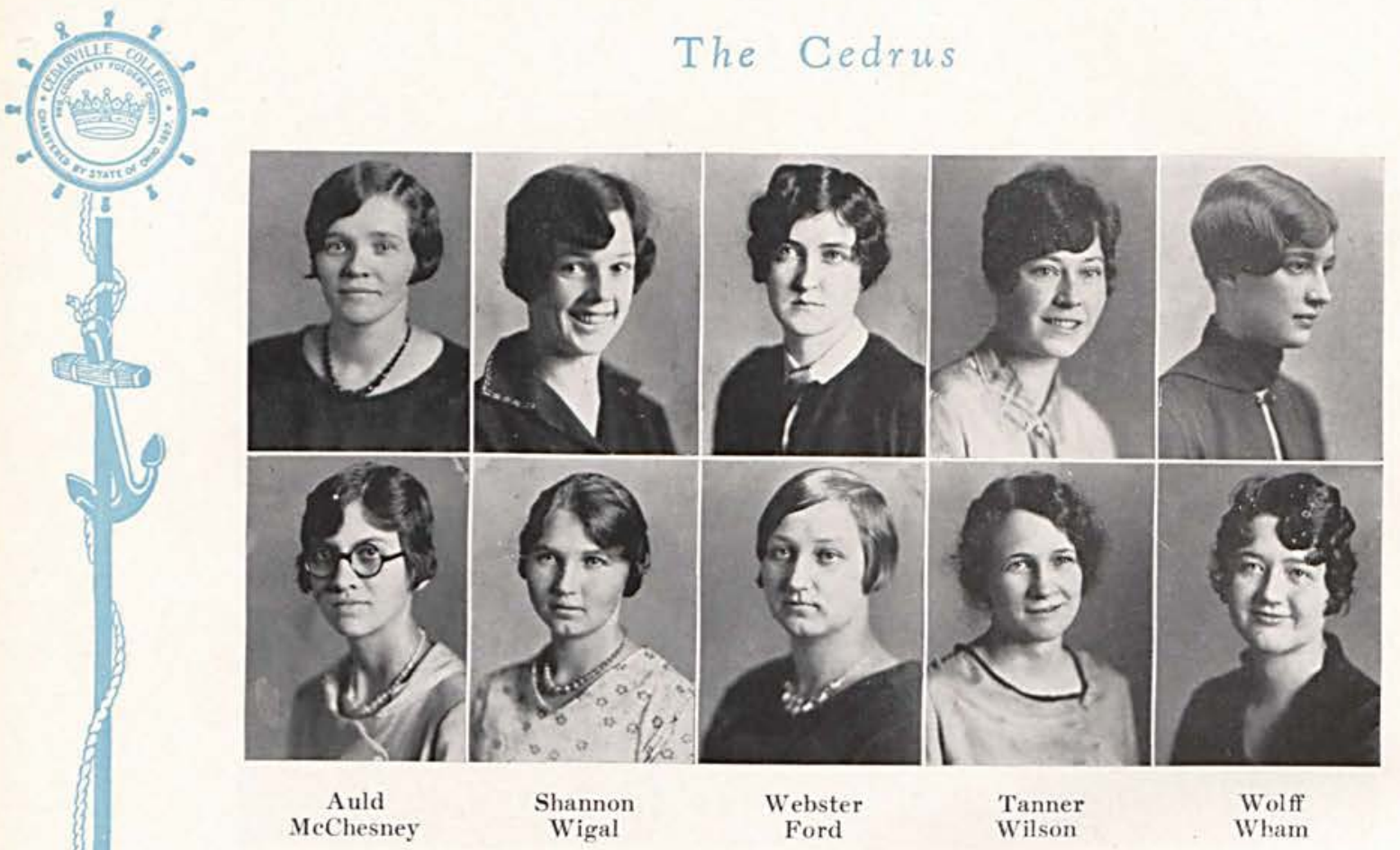

\section{Young Women's Christian Association}

Josephine Auld

Irene Shannon

President

Isabel Webster Vice-President

Lucile Tanner Secretary-Treasurer

Dorothy Wolff. ate Representative

Frances McChesney Social Chairman

Lillias Ford

Edith Wigal. Program Chairman

Nedra Wilson Social Service

Mary Ruth Wham World Fellowship Publicity Chairman

The Y. W. C. A. supplies a need to the college girl in a mental, moral and social way. We have tried, and are trying to take care of these needs this year.

As to the mental side of the college girl, probably our meetings are more valuable than anything else. At first we tried to make the Freshmen girls feel welcome; then the rest of the time before Xmas was devoted mainly to meetings for special days. After our vacation we had a series of meetings on World Fellowship. In these we traveled (?) to the various countries of the world and became almost acquainted with the peoples there. 


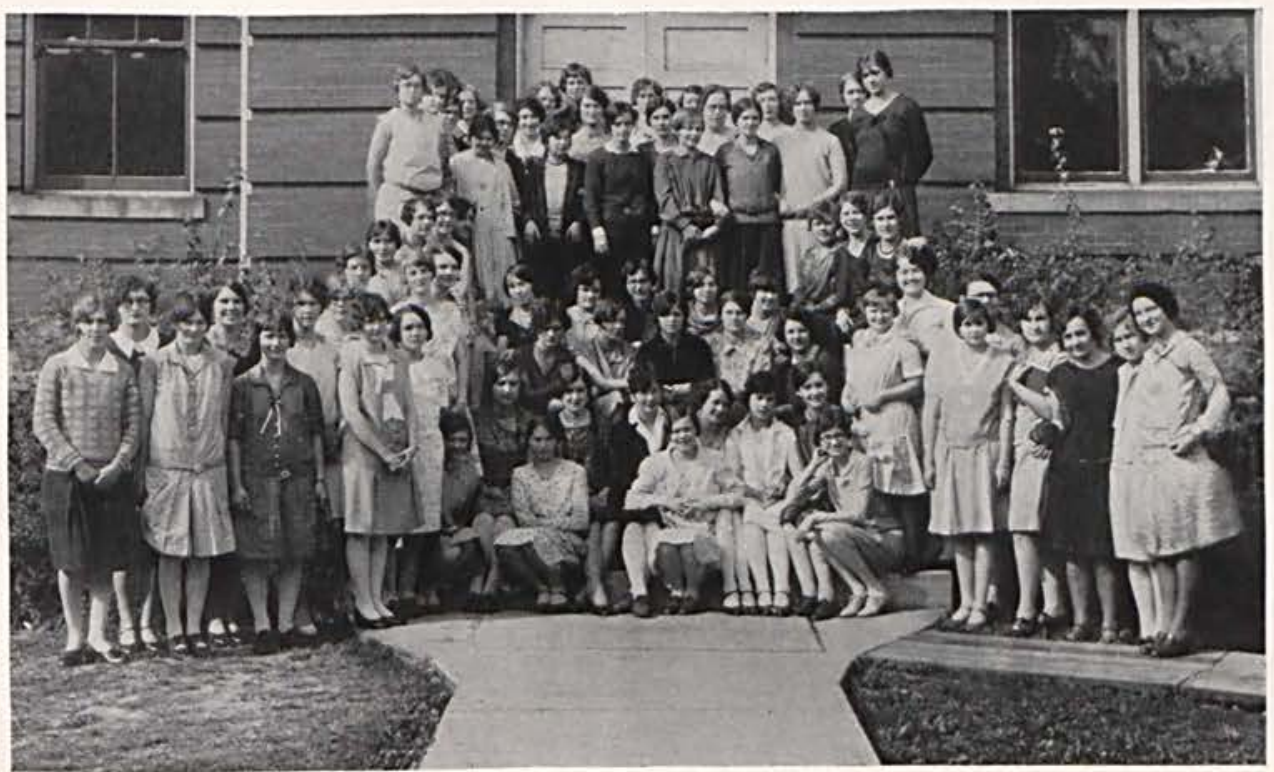

Now since the beginning of the new term, at which time we started with renewed vim and vigor, we have divided our work into projects on the following subjects: Etiquette-How to Dress-How to Live Together-What Every Modern Girl Should Know-Singing.

As to the moral side, a part of each meeting is given over to this phase. Then the project on "How to Live Together" is going to give us some of the differences between churches, keeping the idea of Church Union in mind-to see if it is probable or could be possible.

Lastly, the social side-we first tried to make the Freshman girls feel that they really belonged to the college. Next, the Y. W. entertained at the annual Hallowe'en Party; after that, the Valentine Party. Now we are looking forward to the annual Mock Wedding (boys are not invited this year), and the Formal Banquet. Our formal this year is to be in honor of our Mothers and we are hoping that it will be a success.

This Cabinet has been very faithful and has tried to do its work. Now that our year is almost at an end, we are glad to give the candles to the new officers and to wish them the greatest success.

J. A. 


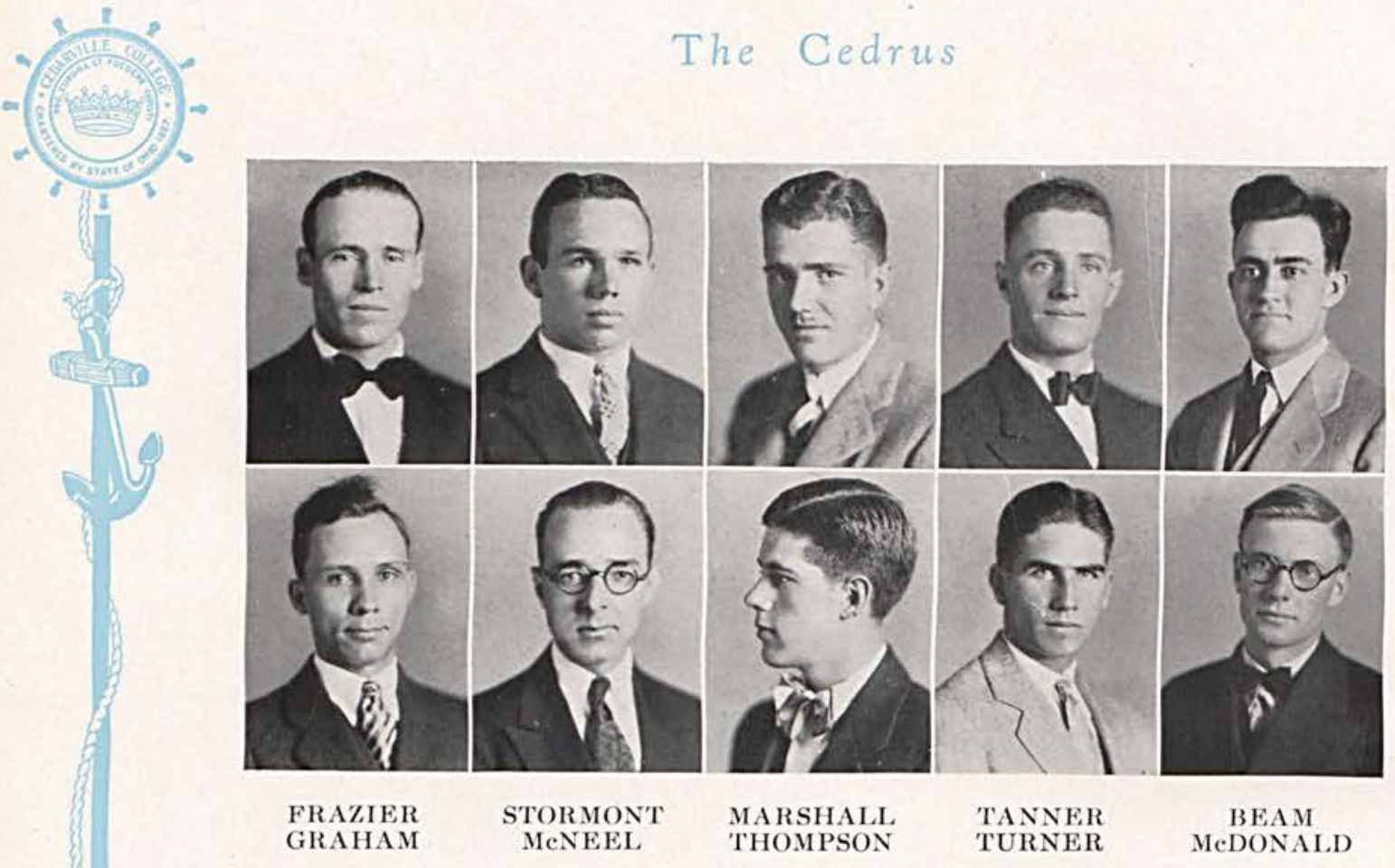

\section{Young Men's Christian Association}

Carl C. FrazierPresident

James C. Stormont Vice-President

Dallas Marshall Secretary

Prof. A. J. Hostetler Faculty Advisor

James Beam Program Chairman

Frank Graham Social Chairman

Clair MeNeel Gospel Team Chairman

Brenton Turner World Affairs Chairman

Robert Thompson Publicity Chairman

W. W. Galloway Community Advisor

The Young Men's Christian Association has an important role to play in the activities of college life. Although the work of the Y. M. C. A. in a small college may seem quite different from that which it does in a large city, it is essentially the same in principle. The Y. M. C. A. was founded in order that young men might be trained physically, mentally and spiritually for better social living. 

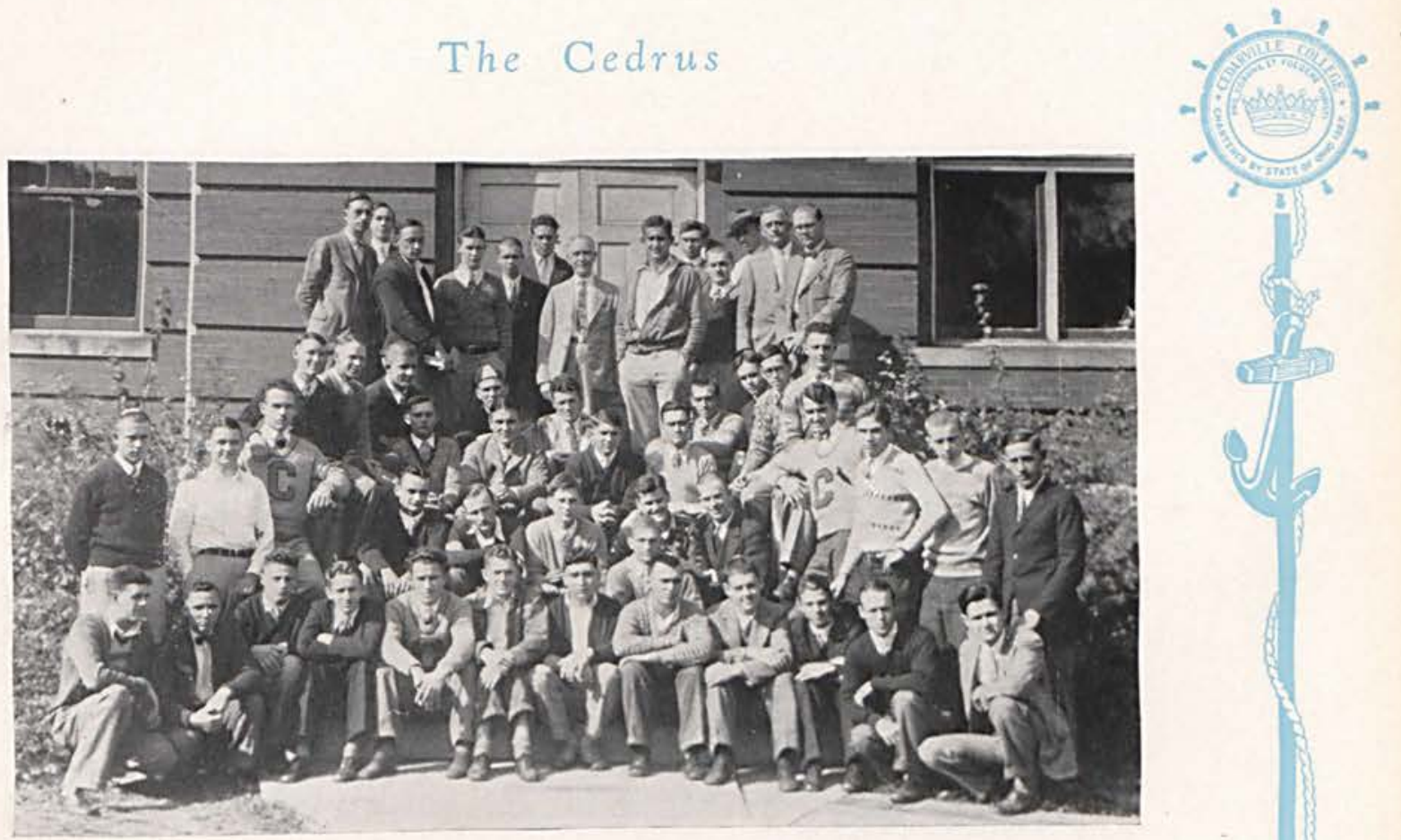

Generally, the college curricular and athletic programs provide for the training of students physically and mentally, but in most institutions of learning little provision is made for the development of the third and most important phase. It is the duty of the college Y. M. C. A. to provide for this need.

Both the Y. M. C. A. and the Y. W. C. A. of Cedarville College recognized the fact that the students can be benefited most by programs that offer something practical and interesting. The spirit of co-operation existing between the two organizations in providing this program is to be commended.

For several years, it has been the custom of the two organizations to give a social immediately after the opening day of college in honor of the new students. In this way the new students and upper classmen soon become acquainted, and the Freshmen are immediately impressed by the democratic spirit of the student body.

It is the policy of the Y. M. C. A. to sponsor, from time to time during the year, social entertainments for the student body.

However, the chief work of the Association is the provision of regular meetings at the chapel hour on Wednesday of each week. It is the purpose of the Y.M.C. A. to provide various programs, bringing before the students, ministers of the gospel, doctors, lawyers, professors, musicians, and men of other professions in order that the programs may be both entertaining and worth-while.

The Y. W. C. A. has co-operated with the Y. M. C. A. from time to time in order that eminent speakers might be obtained.

It is the confession of many members of the Alumni that the memories of the meetings of the Y. M. C. A. are among the fondest memories of their college days, and we hope that the work of the Y. M. C. A. of the past year and of the future will be inspiring.

C. C. F 


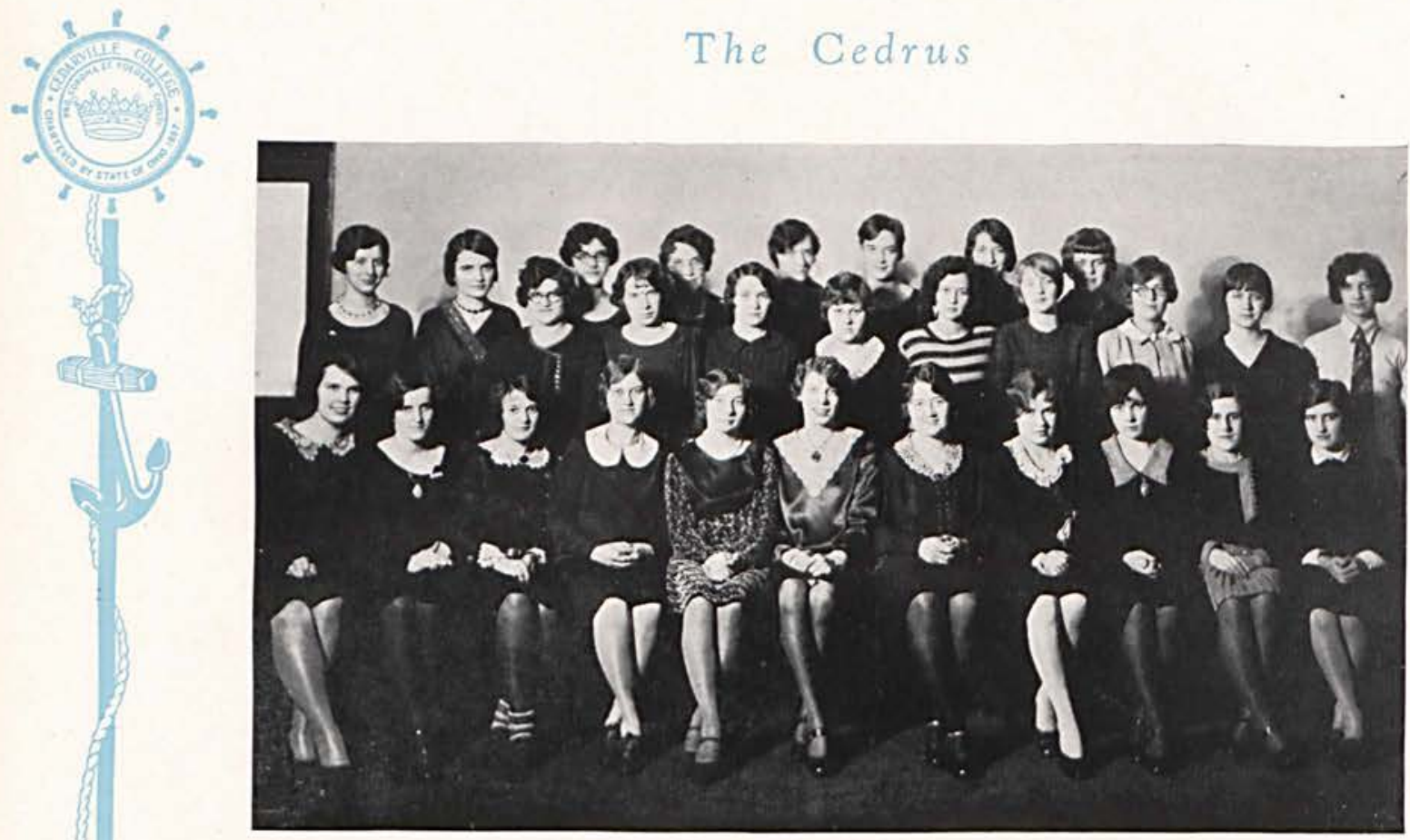

\section{The Girls' Glee Club}

Under the splendid leadership of Miss Lydia E. Berkley, who is a new professor this year, the Glee Club has made remarkable progress. Many two part, three part, and four part songs were learned and the girls took great pleasure in singing them.

The first public appearance was in the Chapel of the College where a generous applause was afforded the Glee Club. At the Day of Prayer for Colleges, two selections were rendered, which were well received.

With the Concert, however, the girls reached the height of their ambition as choristers. Many songs were sung as well as special numbers given. A good crowd responded to the announcement that the Glee Club was giving a concert and everyone seemed to thoroughly enjoy the program.

The Glee Club has also been invited to sing at different churches, schools, missionary meetings, and the like, in towns near Cedarville. 


\section{The Cedrus}

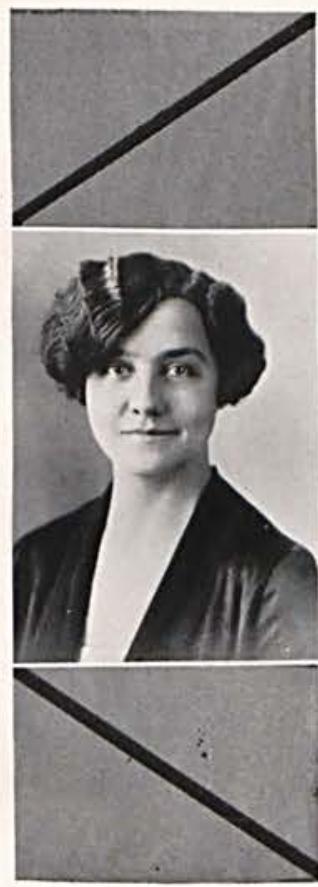

PARRY

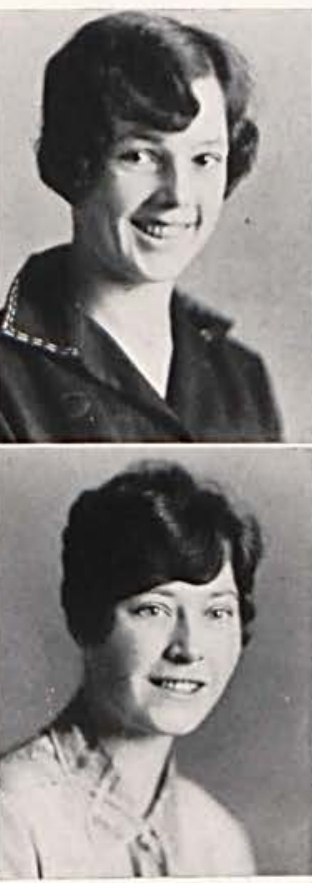

SHANNON TANNER

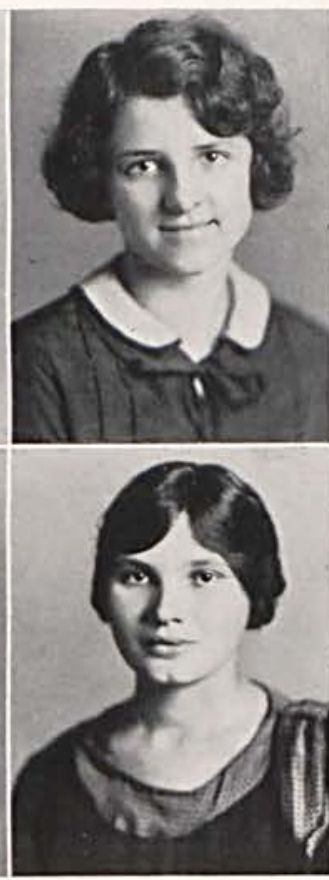

CHANDLER WIGAL
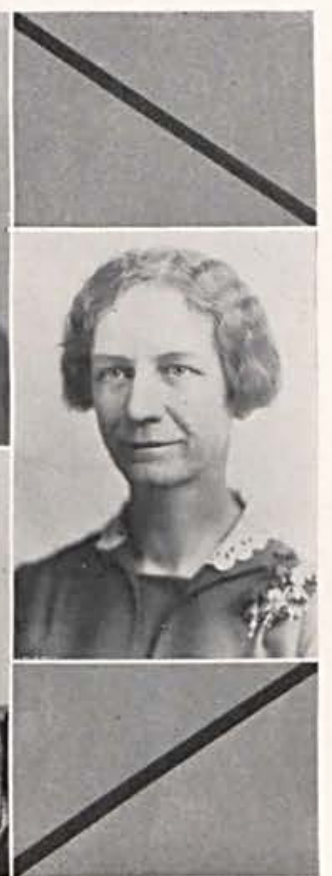

BRISTOW

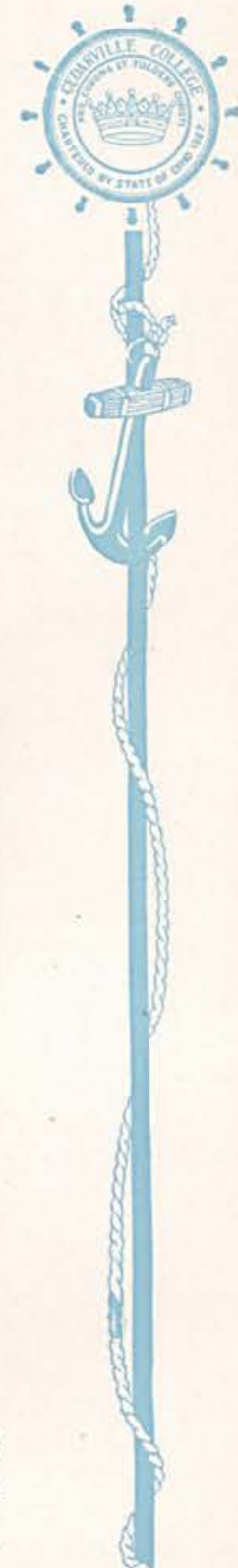

\section{The Girls' Student Council}

The purpose of the Girls' Council is to aid the Dean of Women in making college life more interesting, and in solving the little problems of the girls who room in town. The two upper classes and the Normal Department each have a representative, and a Senior Girl is usually Chairman of the Council.

The members are: Miss Virginia Parry, Dean of Women; Miss Abigail Bristow, Assistant Dean; Miss Lucile Tanner, Junior Representative; Miss Grace Wigal, Normal Department Representative; Miss Margaret Chandler, Senior Representative, and Miss Irene Shannon. 


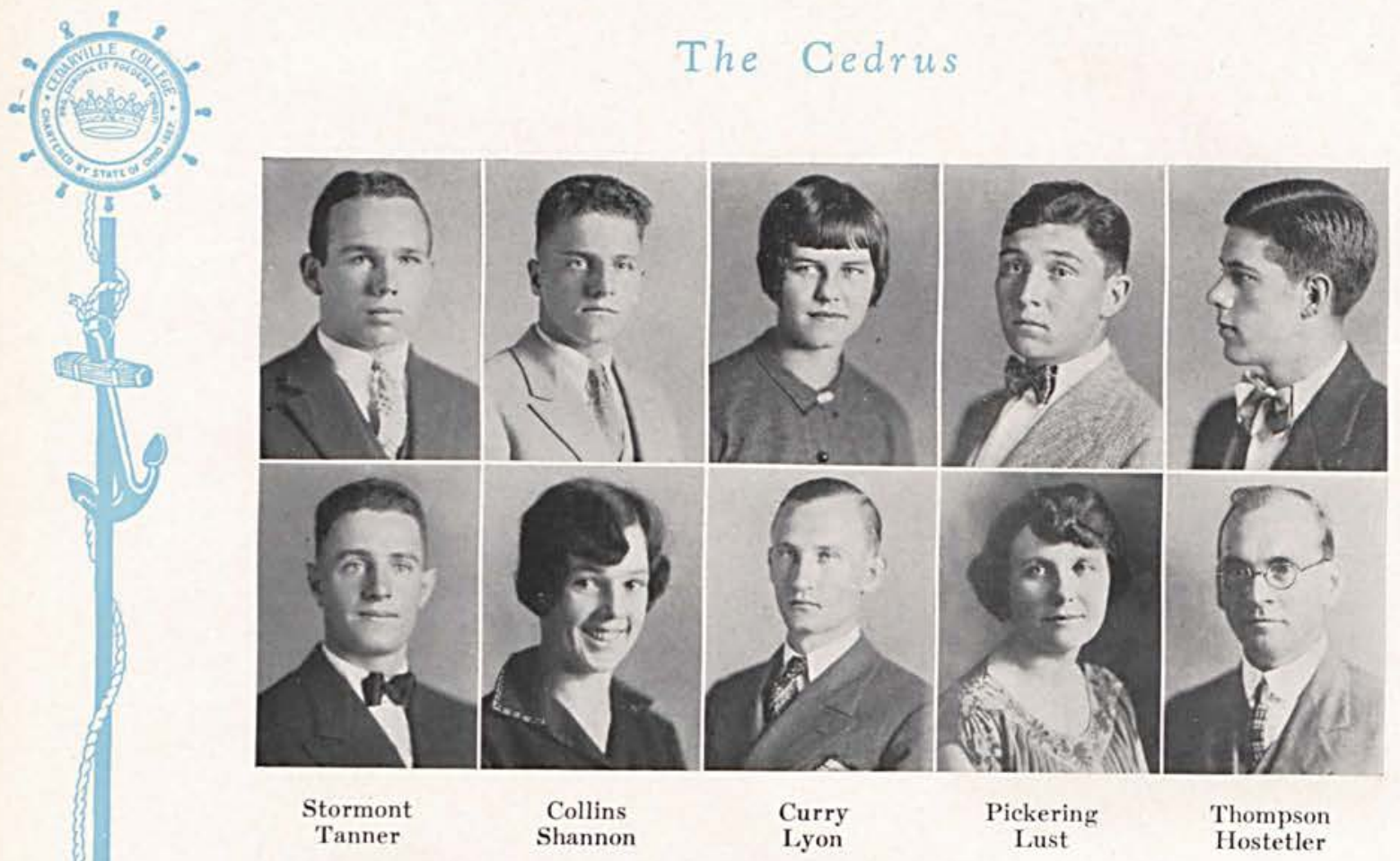

\section{Cedar Needles Staff}

James Stormont
Robert Collins
Robert Thompson
Irene Shannon
Silva Lyon
Wilma Curry
Paul Tanner
Harry Pickering
Miss Jennie Lust
Prof. A. J. Hostetler

Due to the financial difficulties the Cedar Needles Staff was late in getting the paper started. After these difficulties were remedied the Staff published the first issue in November.

Although the paper was cut to one-fourth of its original size, difficulty was experienced in getting students to contribute material for publication. As the time of each member of the Staff was limited and as few of the students were interested in the paper only one more issue was published.

To make a school paper a success at Cedarville College, some sound financial basis must be worked out for its support, and the students as individuals and as a whole must realize a personal responsibility in its publication.

We trust the student body may be able to solve this problem next year, and that editions of the Cedar Needles may again be published regularly.

$$
\text { -J. C. S. }
$$




\section{The Cedrus}
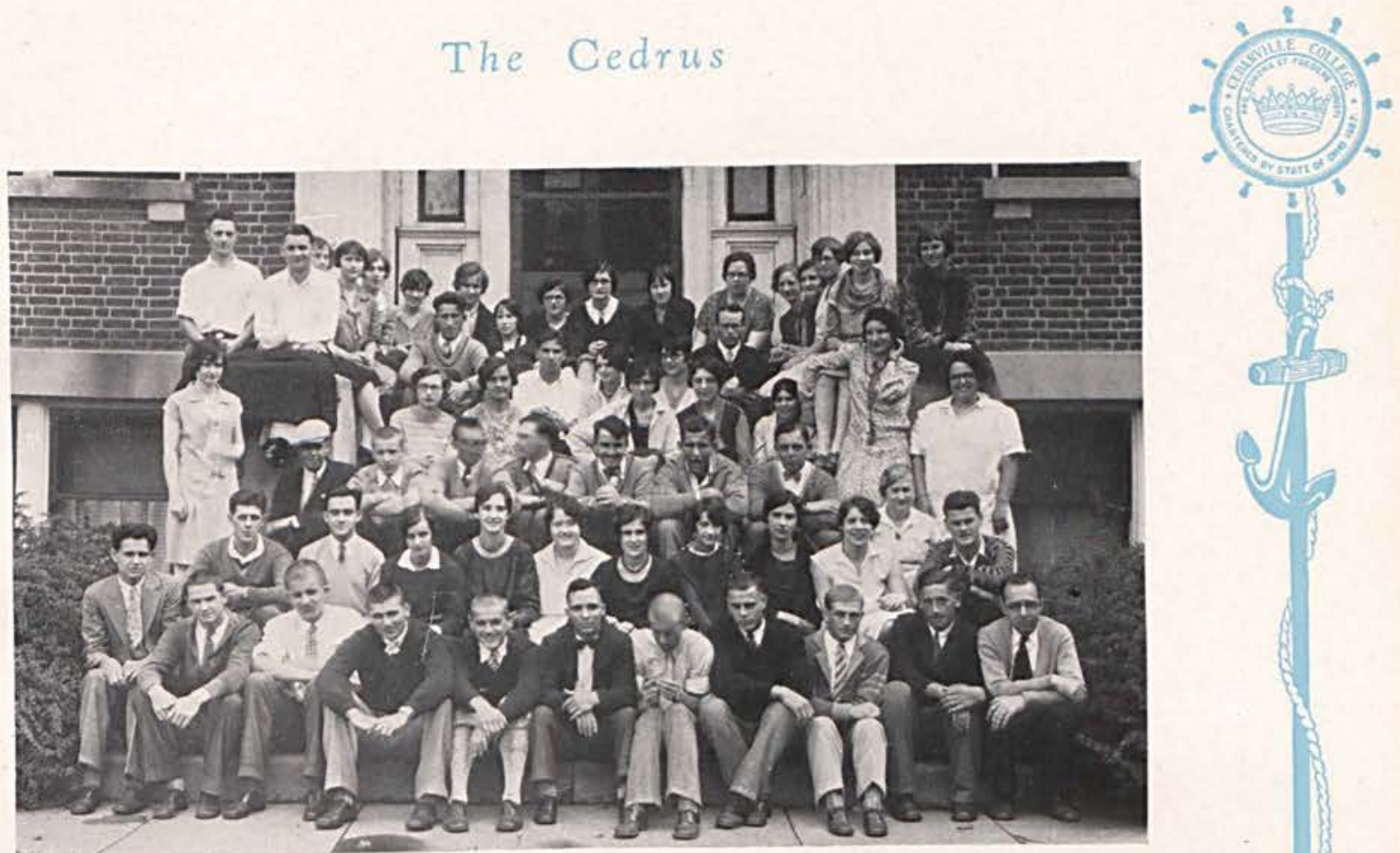

\section{The Cedarville College Club}

Carl Frazier

Steward

Mrs. Clara Morton

Matron

Jennie Hamilton

Cook

"Tingle-ling," says the bell, and then a group of eager college students fall into line and hasten to the dining room. Soon we can hear the rattling of silverware and china. Then it seems to get a little more quiet, for all are partaking of the good and substantial food, prepared by our friendly and cheerful cook, Jennie Hamilton, under the supervision of Mrs. Morton. Approximately fifty students eat here every day.

Each year the club elects a student to be steward for the following year, so last year the duties were given to Carl Frazier. Many a dollar and penny he collects and then tends to the paying of the numerous bills.

The club is situated in the basement of the Library and has three rooms, a waiting room, dining room, and kitchen.

The club is not only a place for eating purposes but here we get to meet new acquaintances and become more closely connected with our friends.

-K. V. P. 


\section{Cedarville College}

TUNE: "America, the Beautiful."

O Cedarville, our college dear, For loyal youth so strong,

For constant faith without a fear, Through all the years so long! O Cedarville! O Cedarville!

Home of our student days,

Forever may thy name abide

And lasting be thy praise.

O Cedarville, we love thy halls

Where precepts true are sought;

We love thy consecrated walls

Where earnest youth are taught.

O Cedarville! O Cedarville!

Joy of the by-gone hours,

Continue through the passing years,

And reach your hoped-for powers.

O Cedarville, we live for thee

With faith unfaltering-

We live, we love, we trust for thee;

Be glad and let us sing

O Cedarville! O Cedarville!

Our trust in thee maintain;

Confirm thy strength in purity,

Thy honor to retain.

O Cedarville, we pray for thee

Our God will love and care

In days of stress in years to be

Oh hear, O God, our prayer;

For Cedarville! For Cedarville!

Preserve her in thy grace;

Defend her with thy mighty hand,

Shine on her with thy face.

-President W. R. McChesney. 


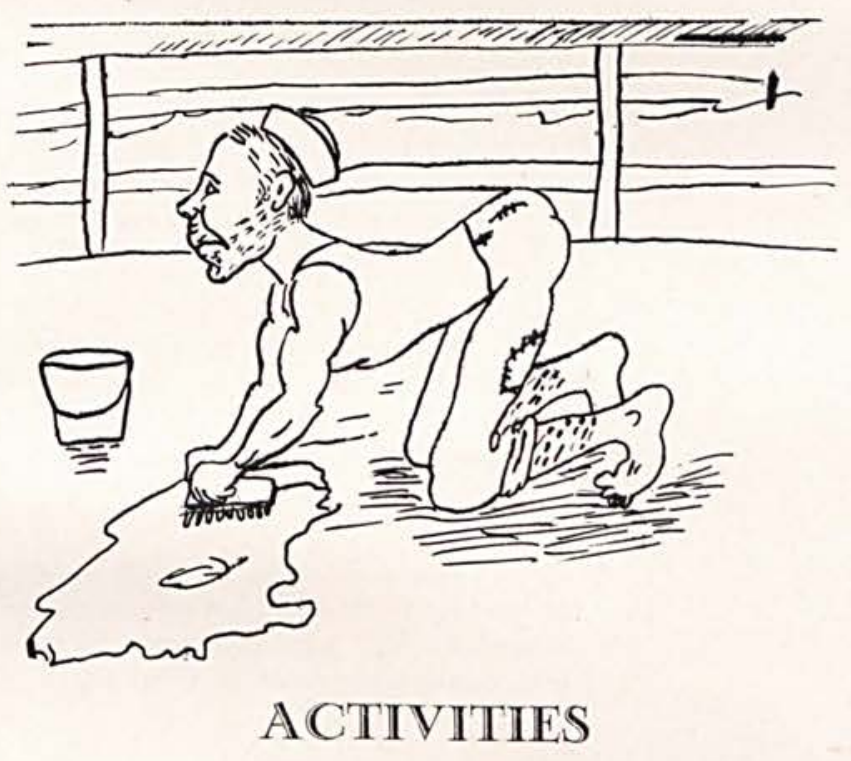





\title{
Commencement Week, 1928
}

\author{
FAREWELL TO SENIORS
}

The passing years can never dim our thoughts, Nor ever time remove the throbbing painThe grief and sorrow that your going brought, The day you left us ne'er to come again.

Just when your hard won fame was at it's crest,

And countless praising voices spoke your name, Fate whispered too and took from us our bestAlas! How like a spectral ghost he came!

Old friends, we miss you, and as years unfold,

We'll hold the memory of you doubly dear;

We'll ne'er forget those happy days of old

And in our hearts we'll always keep you near.

Among these chapel seats no one can fill

The place you held before you heard the call,

And tho'ts of you will linger thru them still

Until the lapse of time shall claim us all.

Farewell! Yet thru the dismal gloom appears A light afar upon a brighter shore,

A heavenly glow, which with the lessening years

Calls us together there forevermore.

-G. W. D. 


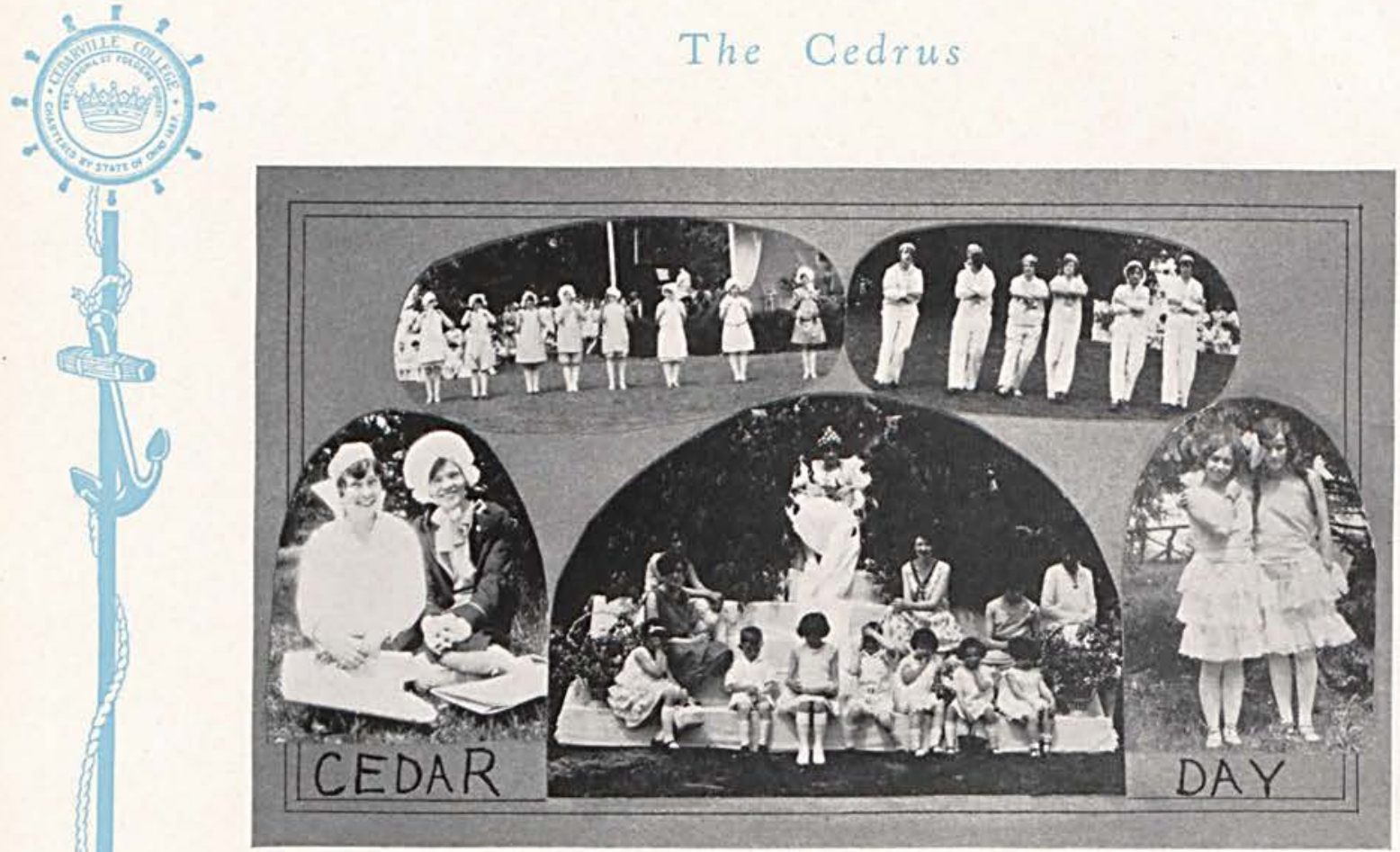

\section{Cedar Day}

Recitations over-flunks as yet unannounced-no more worries-sunshine and happiness-Cedar Day!

It has long been the custom at Cedarville to set aside one day of Commencement week for making merry. On this day the student body, faculty, and community hold a grand assembly on the college campus (on the very sod where our boys have many times carried the pigskin to victory). Here Cedarville does homage to the May Queen and listens to orations; here the students give expressions of their joy in dance and song; here new acquaintances are made, and old friends reunited. Thus we celebrate Cedar Day. 


\section{The Cedrus}

This year we feel was a glorious success. The day, May 29, dawned fresh and flawless. A large and enthusiastic crowd gathered. When all was ready the bugle sounded and the May Queen appeared. Mary Webster, chosen by the student body for queen, looked very, very lovely indeed as she led that long processional. At the foot of the throne-while her followers knelt in humble reverence- she was crowned Queen of the May by last year's May Queen, Mae McKay. Then she ascended the throne and presided over the festivities.

The stage was a toy shop window, and there, representatives of various types of dolls reposed-sleeping. These came to life at the appearance of a beautiful china doll-and then - and then - the gates of fairy land were opened and dollsdolls-dolls came out and danced upon the green. There were Mamma DollsChina Dolls-Sailor Dolls_Japanese Dolls-Dutch Dolls-Spanish Dolls-Pierrot and Pierrette; all these were awakened by the appearance of a single doll, so dainty and sweet, in the person of Miss Norma McCartney of Springfield, Ohio, and they danced homage to their queen.

This was followed by the Cedar Day Oration. Rev. Edward Wones was the choice of the student body, and at the close of his oration we were well content with our choice. In this manner the forenoon passed and little groups began to settle under the trees and to spread the feasts.

A baseball game with Antioch, with the victory for old C. C., was the feature of the afternoon. One might have observed, also, each and every student-not occupied on the diamond-rushing frantically about with a book and pen. No, no, it was not a textbook-merely another of our traditions. The Cedrus was just off the press, and each student was collecting autographs.

Cedar Day — happy is the day — full of tender memories, work, worry, and things accomplished! 


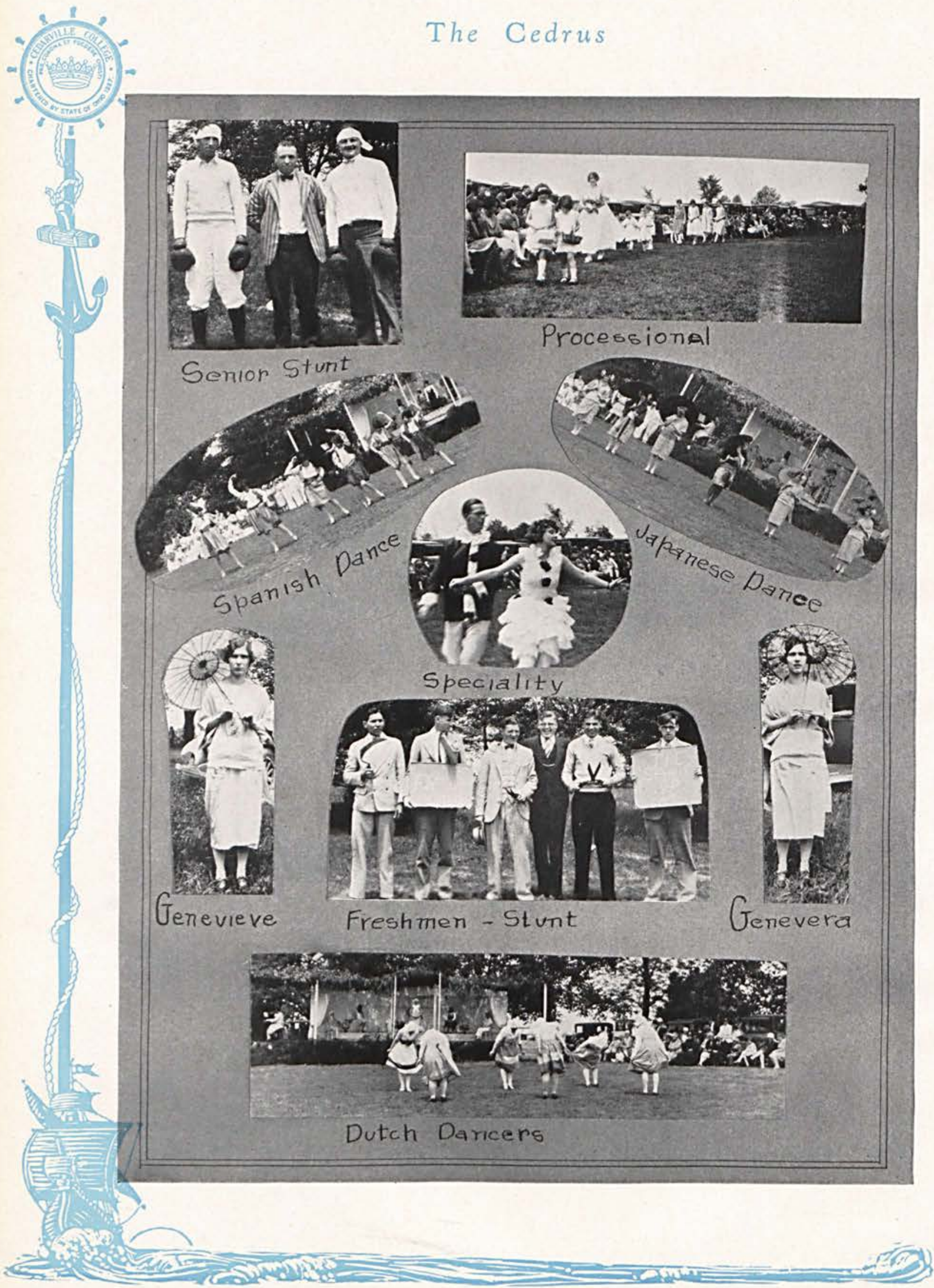

Page Ninety-eight 


\section{The Cedrus}

\section{Baccalaureate}

Commencement Week opened Sunday evening, May 27, when twenty-seven members of the Class of ' 28 and the faculty, followed by the Central Presbyterian choir of Dayton, marched down the aisles of the United Presbyterian church during the processional.

After the invocation had been given by Rev. W. P. Harriman, the Scripture was read by Rev. C. M. Ritchie, and prayer was offered by Rev. J. G. C. Carson.

One of the features of the service was the splendid music rendered by the Dayton choir, under the direction of Mrs. Elsie Freeman Wirsching.

As President W. R. McChesney delivered the sermon in his usual scholarly and convincing manner, the great audience forgot the storm outside, and thought only of the twenty-seven graduates and the great opportunities and responsibilities before them.

\section{Commencement}

The Commencement processional began at nine o'clock Friday morning, June 1 , in front of the Carnegie Library, and ended on the beautifully decorated stage of the opera house.

After the invocation had been given by Rev. R. W. Ustick and several selections had been rendered by the Wittenberg String Trio, Judge Florence E. Allen delivered the address. The audience was greatly impressed by her appeal that every citizen uphold the standards of true Americanism.

Honorary degrees of Doctor of Divinity were conferred upon five ministers of the gospel. The degree of Bachelor of Arts was conferred upon twenty-eight graduates of the four-year Arts course, and diplomas were awarded eight graduates of the two-year Normal course.

Six Crown Pins were awarded, four graduates received honor diplomas, Magna Cum Laude, and four received honor diplomas, Cum Laude.

President McChesney conferred the degrees and awarded the diplomas, after which he delivered the farewell address and pronounced the benediction.

\section{SENIOR CLASS PLAY "THE PATSY"}

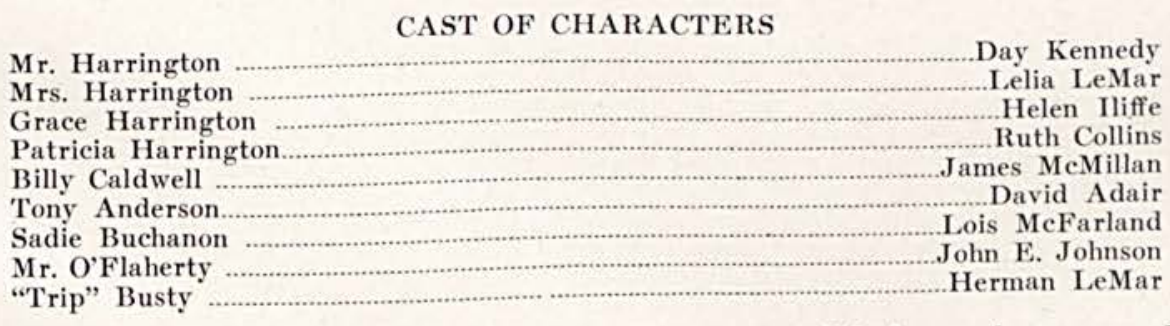

"The Patsy," a comedy in three acts, was presented before a large crowd in the opera house Monday evening, May 28. The members of the Senior class did honor to themselves in this play and merited the approval of the audience. 


\section{The Cedrus}

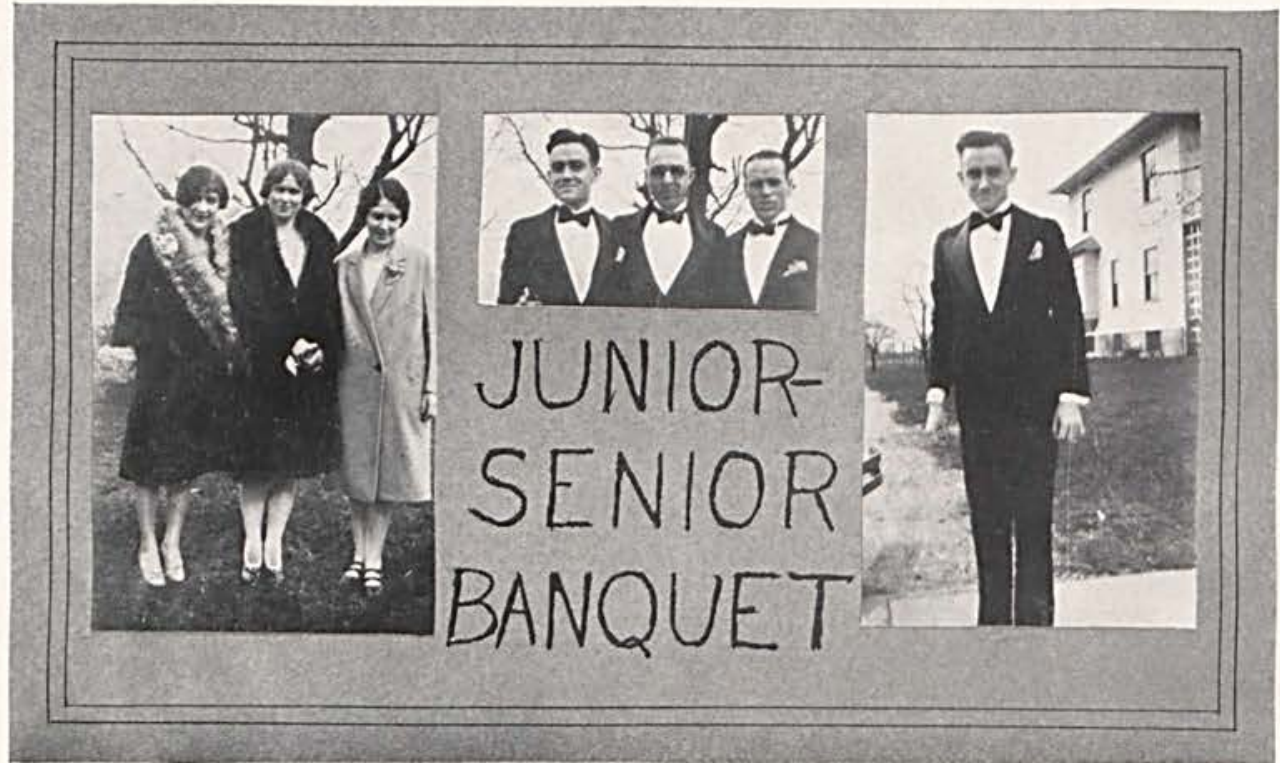

\section{Junior-Senior Banquet}

The Junior-Senior Banquet in honor of the class of '28 was held at the Engineer's Club in Dayton, on Thursday, $\Lambda$ pril twenty-sixth, nineteen hundred and twenty-eight. It was a goodly company of well-dressed men and women who assembled there, and it might be mentioned that the men really looked more comfortable than perhaps they felt.

Little tables were arranged in the dining hall to accommodate the guests. The Senior colors, orchid and silver, were used in the table and decorations. The places were designated by miniature diplomas upon which the names of the guests were printed. The favors were little traveling bags filled with mints. When the guests expressed their thanks for the delightful evening, the Juniors accepted it as truth, not said merely for the sake of politeness. However, you may reach your own conclusion of the matter.

$$
\begin{gathered}
\text { THE MENU } \\
\text { Fruit Cocktail } \\
\text { Baked Ham with Raisin Sauce } \\
\text { Creamed New Potatoes Candied } \\
\text { Pineapple and Chese Ball Salad } \\
\text { Bread } \\
\text { Ice Cream }
\end{gathered}
$$

Music during the dinner hour was furnished by Misses Leila Thuma, Harriet Reeder, and Alberta Snyder.

The evening's program represented the growth of a flower. Rev. B. B. Fleming very capably acted the role of toastmaster. The Welcome, representing the Earth's invitation, was given by Mr. Carl Frazier, president of the Junior class. Mr. Calvin Weimer, president of the Senior class, fittingly gave the Response of the Seed to the Earth. The first petal, Music. was rendered by Miss Helen Iliffe in "Bird Songs at Even Tide," Miss Edith Wigal spoke on "Character," representing the second petal of the flower. Mr. Kenneth Little then entertained with a saxophone solo. The third petal, Athleties, was clearly described by Mr. David Adair. Miss Frieda Chapman presented some very good thoughts in her talk on Education, the fourth petal. After this, the company was pleasingly entertained by Miss Ruth

Burns in two vocal solos, "The Maid of the Ganges" and "When Roses Bloom." Dr. Mc. Chesney closed the evening's program with his earnest, soulful, inspiring talk, representing the stem of the flower, The College. - E. M. W. 


\section{The Cedrus}

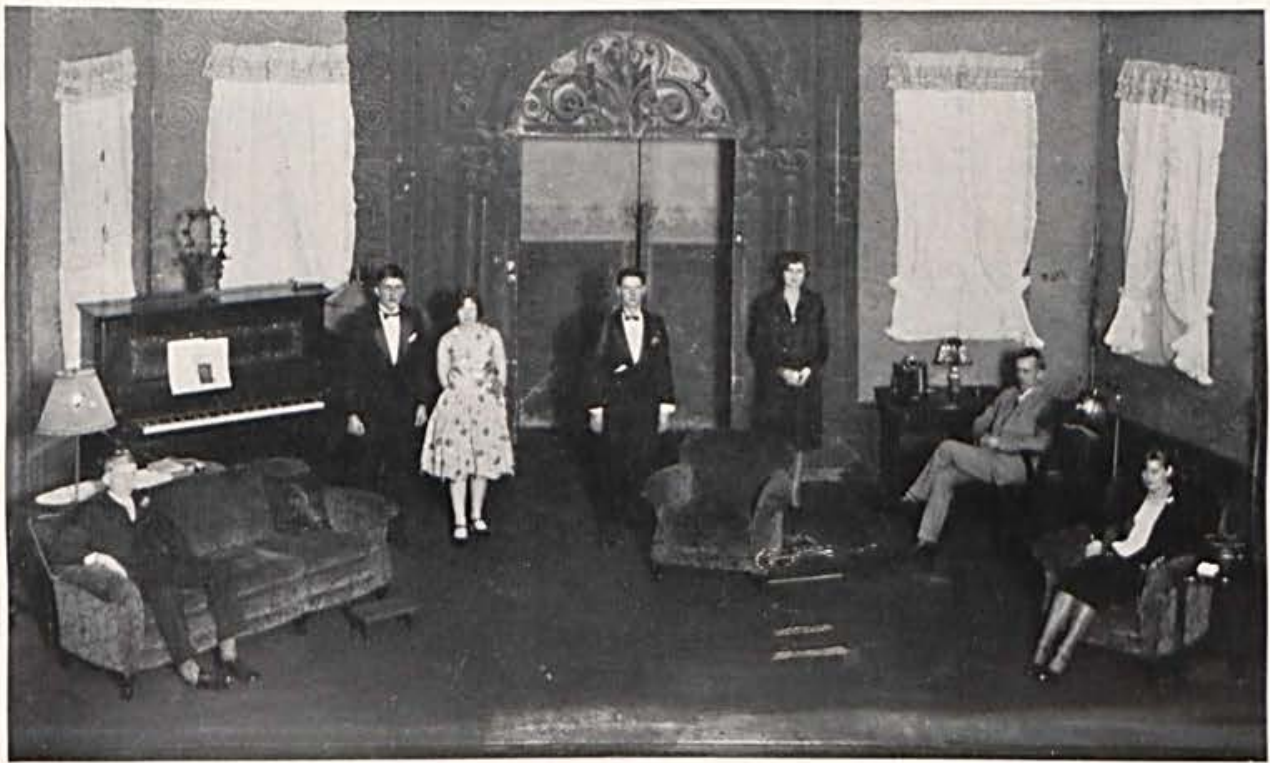

CEDRUS PLAY

\section{"TOMMY"}

CAST OF CHARACTERS

Marie Thurber
David Tuttle
Mrs. Wilson
Brenard
Judge Wilson
Tommy
Mr. Thurber
Mrs. Thurber

"Tommy," a three act comedy, was presented November 29, in the opera house, under the auspices of the Cedrus Staff.

"Tommy" depicts the story of modern young people, and their parents who try to plan their lives for them.

Marie Thurber has two suitors, Tommy Mills, who is the logical choice, and Brenard, a modern automobile salesman, Uncle Dave, a small town politician, sees that Marie's father and mother are going to ruin her life, and saves her at the last moment in a very clever way.

The cast was well chosen, and the presentation gave evidence of conscientious training under excellent direction.

The Cedrus Staff wishes to take this opportunity to express its appreciation of the splendid spirit of cooperation shown by the students who took part, and by Mrs. Borst, under whose able direction the play was presented. 


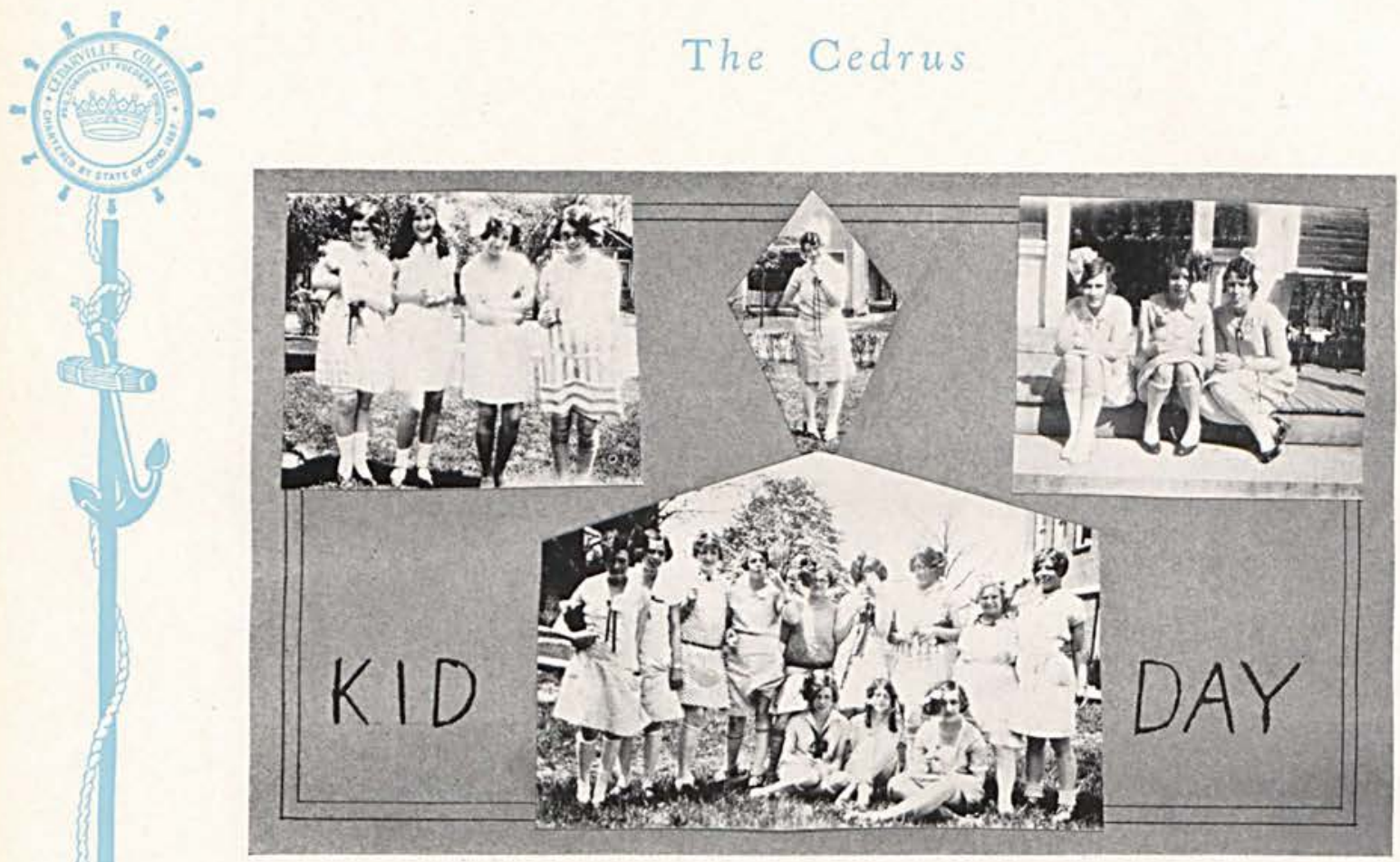

\section{Kid Day}

We usually experience a feeling of pity for those ancient explorers who spent many precious years of their lives searching for the Fountain of Youth, when we realize that the treasures for which they were searching might have been dis covered so easily.

"One is just as old as he feels" is a well-known maxim to all of us; and mosi of us admit its truth, yet how few of us really put it into practice.

It is a custom of the girls of Cedarville College to set aside each year one day, which is celebrated as "Kid" or "Pigtail Day." It is a day upon which much of the dignity of grown-ups is cast aside, and upon which each lady student, from the most frivolous Freshman to the most grave and dignified Senior, becomes a child again-just for a day.

On this day the graceful co-ed styles of dress are discarded in favor of dainty school-girl frocks, long full fashioned silk hose are replaced by various styles of half hose, and boyish bobs are adorned with brilliantly colored ribbons. This is one day in the year upon which the girls may walk about the campus and possibly attend classes, brazenly chewing gum or industriously licking an all-day sucker, without fear of being classed vulgar or uncultured.

On the following day all traces of "Kid Day" have disappeared, according to outward appearnces, and the children have grown into full-fledged college students again-and this is well. However, we trust the beautiful custom is not in vain, and that by means of it the lives of these girls may ever be pervaded by the Spirit of Youth.

-C C. F.

Page One Hundred Two 


\section{"The Valentine Party"}

On Monday, February 18, the Y. W. invited the Y. M. to a Valentine Party. Each boy and girl was told to bring a Valentine and put his or her name on it. And the girls were told to drop theirs in a white box decorated in red, and the boys were to put theirs in a red box trimmed with white.

We all enjoyed games until several fellows declared that they would not play another single thing until they had something to eat. The boxes were passed around, the girls' to the boys' and vice-versa. This way everyone had a partner during the tete-a-tete. We had heart-shaped cookies with red sugared tops, and brick ice cream with a heart in it. As the fellows could not capture any of the girls' hearts, they tried to see how many brick hearts they could down. Much to their sorrow they could not get hold of many, for the committee was a wise old bunch and took good care of their hearts.

S. M. C.

\section{"The Hallowe'en Party"}

Tuesday evening, October 30 , the Y. W. C. A. invited the faculty and students to a masquerade party in the "gym."

We had some trouble recognizing our fellow students as witches, ghosts, oldfashioned peoples and others. About $8: 30$ all joined in a grand march past the judges. Prizes were awarded for the most original costume, and the craziest costume; there was also a booby prize. As soon as the masks were removed a king, Harry Pickering, and a queen, Lucile Tanner, were crowned.

Everyone joined in a circle, and we played games until supper was announced. Very little time was wasted in falling into line and everyone was amply paid because-such a supper!-mashed potatoes, gravy, roast pork, slaw, hot rolls, butter, coffee, and then ice cream and cake to top it off.

Everyone went home pronouncing the $\mathrm{Y}$. W. royal entertainers.

-E. J. M.

\section{"The Committal Service"}

Each year after the membership campaign of the Y. W. C. A., it is their beautiful custom to hold a candle-light Committal Service for the initiation of the new members.

This year, as usual, it was held in the College Chapel. There was the committal service accompanied by appropriate organ and vocal music, and then the close of the service wherein all girls took the national pledge and lit their candles at the big candle, terminating the program by singing the national song, "Follow the Gleam."

Afterward, we and our guests enjoyed a social hour and refreshments. 


\section{The Cedrus}

\section{President's Reception}

On March 15, the Faculty and students gathered at the home of Dr. and Mrs. McChesney on Xenia Avenue. Nearly two hundred students and friends were present.

Because of the nearness of St. Patrick's Day a very delightful color scheme of green and white was used. A very appetizing two-course supper was served.

The entertainment consisted of a musical program. It was made up of vocal solos, piano duets, violin and 'cello duets, and the Girls' Glee Club sang "The Bells of St. Marys."

The students and friends always have an enjoyable evening each year at this reception.

\section{Mock Wedding}

The annual Mock Wedding of the Y. W. C. A. was held at the home of Genevieve and Genevera Jamieson, April 19, 1928, with over fifty girls present.

Before the wedding, Miss Mary Ruth Wham at the piano rendered several musical selections. Miss Ruth Burns sang "At Dawning," and Miss Helen Hiffe sang "I Love You Truly."

The bridal party entered to the Lohengrin Wedding March. The ushers, Mr. Irene Shannon and Mr. Nedra Wilson, entered first, followed by the bridesmaids, Misses Mary Webster and Helen Iliffe. The maid of hoonr, Miss Lucille Howard, who was gowned in orchid taffeta and carried pink rosebuds, preceded the two dainty flower girls, Gertrude Gilmore and Norma McCartney. The bride's nephew, Master Jean Morton, served as ringbearer.

The bride, Miss Martha Mitchell, was attired in white satin back crepe made period style. She carried an exquisite bride's bouquet of rosebuds and baby's breath. Her veil was of tulle, and was caught in place with orange blossoms. She entered on the arm of her father, Mr. Claribel Hunt. The party was met at the beautifully improvised altar by the groom, Mr. Lois Estle, and the best man, Mr. Ruth Collins. The ceremony was performed by Rev. Lelia LeMar, D. D.

After the ceremony had been performed, the bridal party was seated at the bride's table, which was beautifully decorated, and the other guests were seated throughout the spacious rooms. A delightful luncheon, consisting of salad, buttered rolls, pea patties, chicken a la king, ice cream, and bride's cake was served by the Freshmen girls.

The party was slightly disturbed by a group of people, who were neither among the "400" of Cedarville, nor among those who received invitations to this exclusive wedding.

The bride and groom departed immediately after the luncheon on an extended trip, the destination of which was unknown.

The guests left, each tenderly carrying a piece of wedding cake with hopes and visions of what she might dream.

-I. C. W.

- W. C. 


\section{"Bonfires"}

A number of firelight "pep" meetings were held during the fall on the campus. These were attended by a fair percentage of the students.

"Pep" programs which were exceedingly interesting were given and usually we had "hot dogs"-free!

One such assembly had a singular termination. After we had dirged our defeated rival, Antioch, we "snaked" it over town, and discovered, in front of our president's home, a burning "fiery cross." Some of the boys soon disposed of it.

The bonfire meetings are worth while when we make them so. As our "bonfires turn out," so our "spirit is inclined."

\section{"Joint Y. W. and Y. M. Reception"}

The joint Y. W. and Y. M. reception at the Alford Memorial Gymnasium, Tuesday evening, September 18, provided for the purpose of establishing a more intimate relationship among the students and faculty, was a delightful and memorable occasion.

The students were greeted at the door by a reception committee whose presence radiated a glow of welcome and cordiality, and passed into the gymnasium feeling satisfied and complacent concerning the friendly democracy of our school.

Enjoyable games and "stunts," in which the entire assemblage participated, were interrupted at varied intervals as a defiant looking Freshman was mysteriously propelled toward the exit by members of the upper classes. Meanwhile business at the local barber shops flourished noticeably.

Following the entertainment, delicious refreshments were served and, reluctantly, the reception was brought to a close.

The party was thoroughly enjoyable and beneficial to all who attended. Even the Freshman boys, congregated in front of the gymnasium to discuss the indignities to which they had been subjected, lost their grievances in the spirit of the occasion and looked forward with eager anticipation to future activities. But, high above the tree tops, a pale September moon, as if unable to control her mirth at the ludicrous appearance they presented, took one final, fleeting glance-and fled hastily behind the clouds.

-Ellis Rowsey.

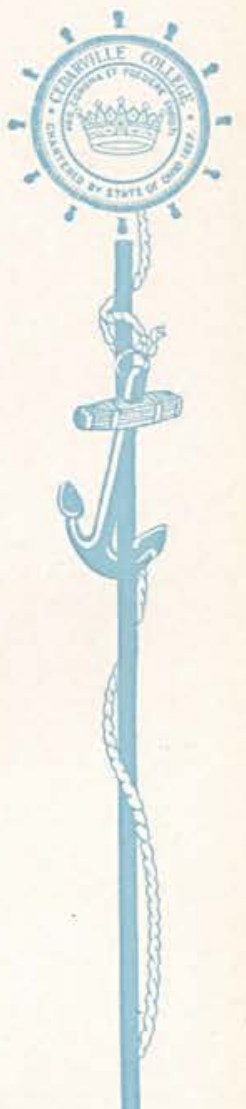




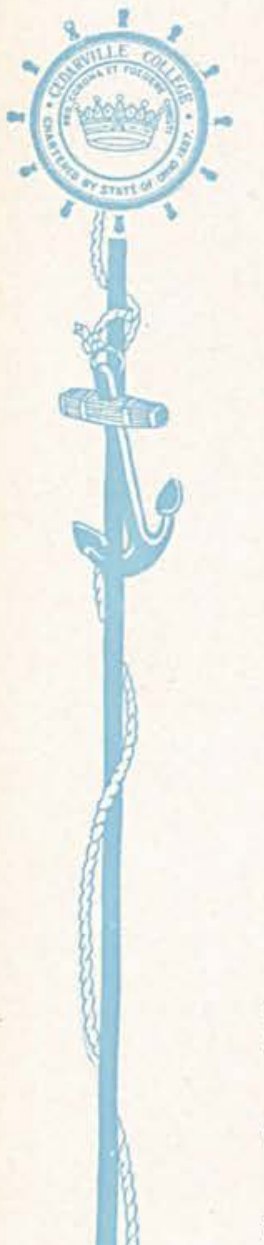

\section{The Cedrus}

\section{"The Silver Tea"}

Due to inclement weather, there were not very many who attended the tea last year. But those of us who were there spent an enjoyable evening. We were highly entertained by piano and vocal selections. Frances McChesney told us all about "Lady Clare." Miss Chapman gave us a very simple rhyme in the words of the different poets. The whole program was unique because it was almost impromptu. We had intended to present a short play, but due to the illness of one member of the cast that was impossible. However, the best part was the last-

This year the tea was held in the Library reading room in conjunction with one of the recitals of music. Almost everyone who attended the recital also patronized the tea, and a social hour was enjoyed.

"The Tea."

\section{"The Y.M. C. A. Rabbit Supper"}

Shortly after the close of the membership drive of the Y. M. C. A., a rabbit supper was held in the gymnasium for the new members. A delightful supper was had by all. The rabbits were the result of the fellows' hunting season.

We were honored by the presence of Mr. Galloway, who gave a very interesting talk after the supper. Several members of the faculty also gave short talks.

Everyone departed in happy spirits and convinced that the Y. M. C. A. is a vital factor in the lives of the young men of the college. -B. R. T.

\section{"The Y. W. C. A. Formal Banquet"}

After the etiquette project in Y. W. last year we girls wanted to "air" our knowledge. And so we had a formal banquet in the gymnasium.

We sat at tables arranged in the form of our triangle, and the favors and decorations were nicely in keeping.

Our speaker was Dr. Jamison, Dean of Women at Muskingum. She is an able and entertaining speaker, as well as a friendly and experienced physician. She held our undivided attention during her address.

Entertainment was furnished by Miss Sarah Brown, also of Muskingum, who played violin solos and sang.

Our mothers and friends helped us with our delicious dinner.

Every girl had a good time and every girl wants another. 

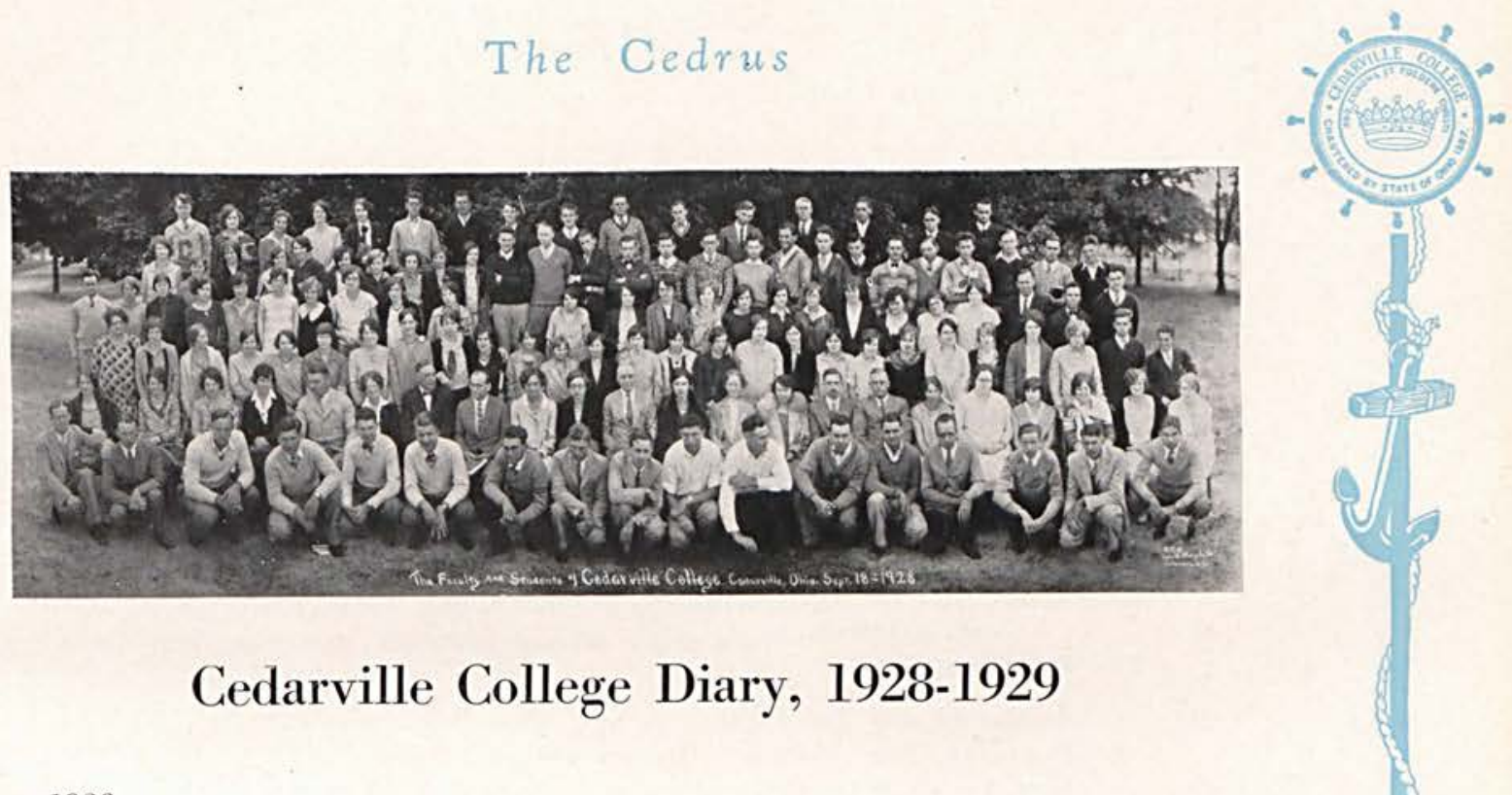

1928

May 26-Muskingum loses, 7-5. Umpire bribed.

27 -Cedrus autographers get writer's cramp.

28-Seniors stage "The Patsy."

29-Cedar Day. No airships.

30-Memorial Day for the Blue and the Gray.

31-Board meets at college. Team meets Antioch. Both successful. Grads gobble at Gym.

June 1 -Cap and Gown parade, two by two on the Avenoo. Judge Florence Allen sentences class.

14-Republican konclave at Kansas City. Hoover sweeps.

26-Democrats at Houston. Waste of time.

July 4-Gunpowder day. Three scars for the red, black and blue.

Aug. 3-Collitch almost gets $\$ 10,000$ from N. Y. Ho! Hum!

26-Xenia Homecoming. Old bill owers return.

30 - State Fair's big day. Do people still go there?

Sept. 2-Labor Day. No work.

5-Clifton's first Republican rally. Billy Sunday strong. Collection weak. 10-Students arriving by train and bus. Some busted.

11-Cash and register day. Feetball practice.

12-Grand opening. Fess and Begg beg off. 120 students, 15 athletes. YWelcome Tea hee.

13-Jinx number day for adm. card losers. Song service on Chillicothe street.

14-Parson Jamieson in chapel. Footbawlers begin to tire. 


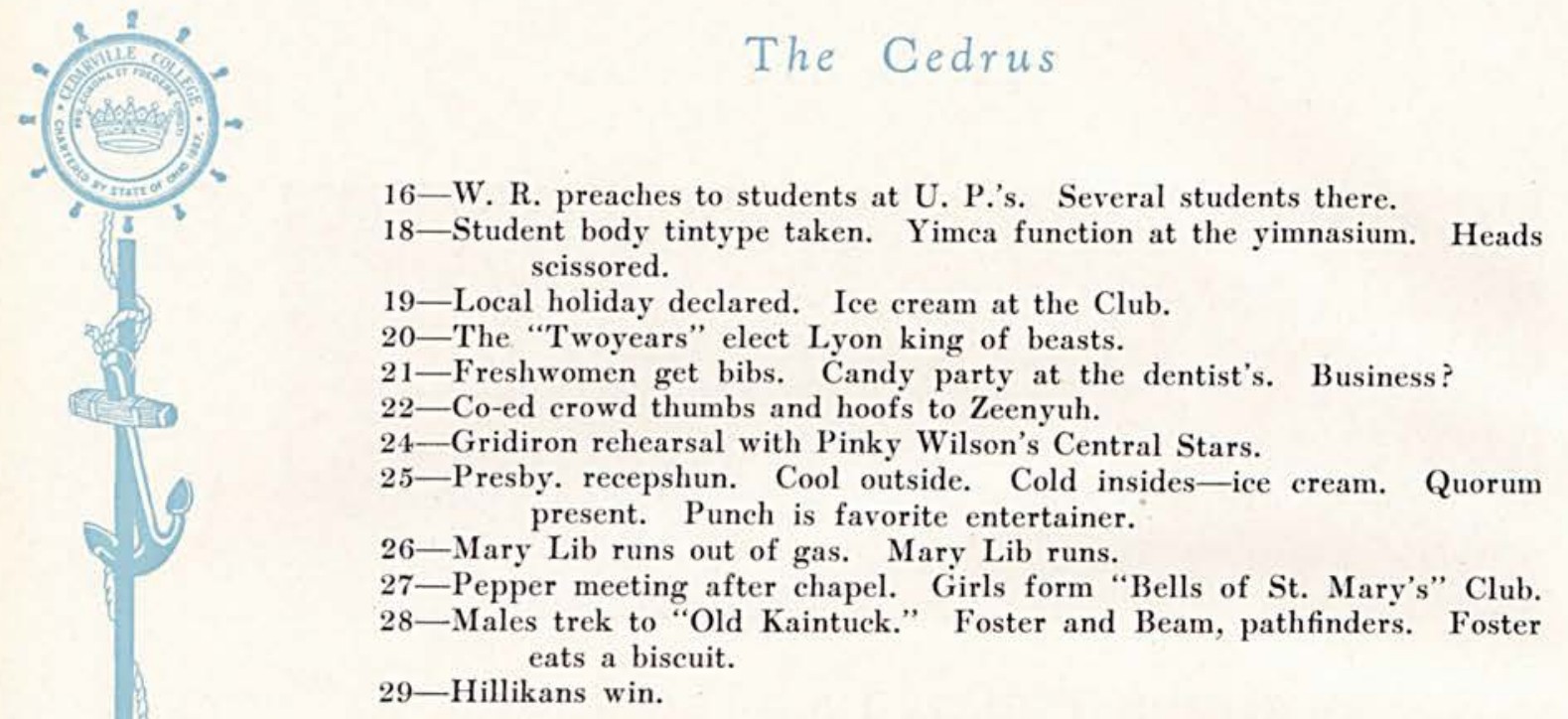

Oct. 1-Judgment day for Fresh. femmes. Big Ben disappears.

2 -Fac. Jun. Sen. photos. Juniors put on feedbag.

4-World's Serious. Cedar groups, unserious. Yell meeting.

$5-$ H. S. almost defeats Lanier.

6-Div. "A" beats Div. "CC" 31-6. Long division.

11 - Jeanhilmaryuth go barefeeted to Cliffs. Soph. phoodphest. Barracks upheaved. Wilson taken for a ride.

12 -Old Man "River" Grande comes tomorrow.

13-Xtremely hot. Rio hot. 12-0.

15-Philos. meet and organize. Philas. disorganized.

17-Prof. Hostettler says, "Since skirts aren't worn any longer." Pun?

19-Wilmington treats us fine-before and after the game.

22 - Fresh. feedsters munch at Morton's.

23-MEthodists entertame.

25-Lucky Luckner packs 'em in and mashes a dime at Opera.

26-Second Republican rally at Clifftown. Curtiss-Cooper warm at festival. Badge beggars busy.

27 -Kent 27 on the 27 th.

29-WLW-“World's Largest Windbag" becomes bothersome.

30 - False face frolic at the arena. On the ladies.

31-Girls clean up Gym. Hays cleans up square.

Nov. 3-General Motors parade to OSU game.

5-Morgan's men massacreed. 39-0.

6 - Selection Day. Hoover barely gets in.

8-UP function. Third and last. At last.

9 -Wilmington wins-they always do.

12 - Seedrus playpractice.

14-Hartman House Harshly Handled.

15-Stag bunny bake at Alford. Boys eat. Galloway talks.

16 - Hartman housebreakers harshly handled.

17-Last act. Rio seventy-something. They haven't such a bad team.

26-Full dress rehearsal. Furnace goes Boom and bum.

27-“Tommy." Three acts in three hours.

28-Basketbawl steams up. Soffeed at Rumbaugh's.

29 - College closed by Pres. Coolidge's edict.

30 - Turkey's revenge day. 


\section{The Cedrus}

Dec. 8-Miss Berkley's Musikale. Jackets ease Antiarck.

14-Four Filipeens. St. X is the unknown quantity.

19 - "Yellows" finish two points behind Muskings.

21-OWes. They're still too good for us.

22 -Vacash. Season of mailman's delight.

25-Check-book-of-the-month Day.

1929

Jan. 3-Grand reopening.

8-OHten Northern Loozez.

9 - "Acey-Deucey" mania starts.

11-Lyceum. Schubert Quart. sings a couple of his songs.

15-Jingle bell time. Snow--auto coasting.

18 - Boys go west. Hanover handles them over.

19 - Bliss blisters us.

22-Rooms topsy-turvied.

23-More dittoes dittced. Chevy wreck at Selma.

26-Violet ill.

29-Exams. Studes play "ask me another" game.

Feb. 1-Bobsled coasting-drugstore roasting.

2-Sausage day. Me and my shadow.

4-Secondsem. Treasurer collects check autographs.

8-Day of Prayer. Fundamentalists start fundameddling. Fun but no funds.

9-Heaviest snowfall. Revenge on Rio.

12-Poppa and son supper. Dotters out coasting.

14-UPYoung Pholks Confab.

18 - Hearts party at $\mathrm{Jim}$.

19-Wilmington 35-25. Their luck never changes.

22 - County ball tourney. Locals attend free and freely.

26-High water. Billy Sunday traces washed away at Clifton.

March 4-Hoover goes to work.

11-Finalyceum. Jubilees. Jubilant.

12 - Irons, Iddings, Wilson, go swimming. Three born every minute.

14-Gleeful clubbers' concerto.

17-Emeralday.

18 -Collegians attend collegiate "Good News."

27- "Billy" (not Sunday) at Opry House.

$28-\mathrm{BB}$ interclass clashes.

Apr. 4-Spring vacation and spring weather coincide. Warm outside.

10-May Queen ballotally. No stuffing.

11-Diamond opener. Not so good.

13-Diamond seconder. Improving.

16-Mock weeding.

Wilma Curry,

Robert Wilson,

Elmer Jurkat.

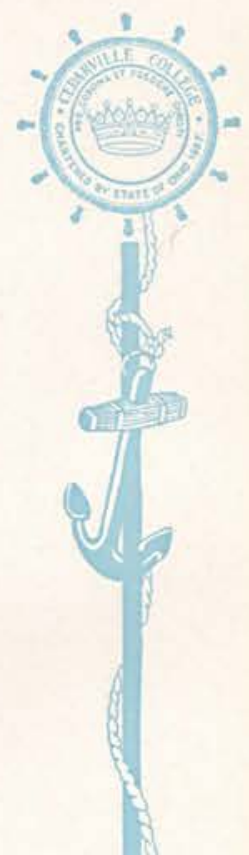




\section{The Cedrus}

\section{Humor}

Mary-"Would you put yourself out for me?"

Wendell- "Certainly, dear."

Mary- "Please do; it's after twelve and I am sleepy."

Iddings - "My brother graduated with one hundred and three degrees."

Coy- "Impossible." Day."

Iddings-" Not at all. He worked himself up into a fever on Commencement

Nedra- "My father says he thought nothing of studying five hours a night." Frances- "Well, I don't think so much of it myself."

Brenton- "Honestly, honey, you're the first girl I've ever loved." Wilda-“Gosh, you must think I don't realize it."

Hilma- "Don't you just love overpowering men?"

Jean-“Gracious! I've never overpowered any men."

\section{WE DON'T UNDERSTAND}

Differences in longitude of Prof. Jurkat and Betty Badstuber.

Why Sarah Margaret and Lenore can't get college men.

How Blair finds time to study.

How Jean sprained her ankle.

Why Mary "Lib" falls so hard.

Why Eloise likes Chemistry so well.

How Jake's books came to be on Iliffe's steps.

Page One Hundred Ten 


\section{The Cedrus}

\section{Our Advertisers}

The Cedrus Staff wishes to call to the attention of the students the fact that we are somewhat indebted to "Our Advertisers" for the publication of this annual.

It is largely through the aid of these business and professional men, who have reserved advertising space, that the publication of "The Cedrus" is possible.

We sincerely hope the students will realize our duty to these friends of the ccllege, and that they will show their appreciation by patronizing them.

\section{CEDAR VILLE}

Robert Bird \& Sons Company

Ye Cedar Inn

Cedarville Bargain Store

Cedarville Bakery

Cedarville College

Cedarville Herald

Cedarville Lumber Company

W. L. Clemans

I. C. Davis

The Exchange Bank

H. W. Evans

F. E. Harper

Hagar Strawboard \& Paper Company

Home Clothing Company

A. E. Huey Hardware Company

McCampbell's Exchange

Gibert McCoy

C. E. Masters

Miami Valley Cooperative Milk Producers'

Association

M. C. Nagley

Richards Drug Store

W. W. Troute

Thomas \& Crouse

Ralph Wolford

\section{INDIANAPOLIS}

Stafford Engraving Company

XENIA

The R. D. Adair Company

Anderson's Flower Shop

L. S. Barnes \& Company

The Criterion

Eichman Electric Shop

Galloway \& Cherry

Geyer's

The Hy-Art Shop

The Lang Chevrolet Company

MeCurran Brothers

Osterley Millinery Company

Pidgeon Battery Company

Valet Press Shop

L. A. Wagner

The C. A. Weaver Company

Wheeler Studio

Xenia Auto Necessity Company

Xenia Candy Kitchen

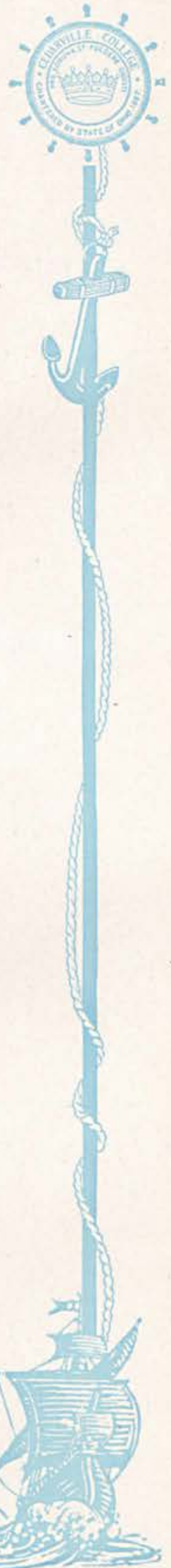

Page One Hundred Eleven 


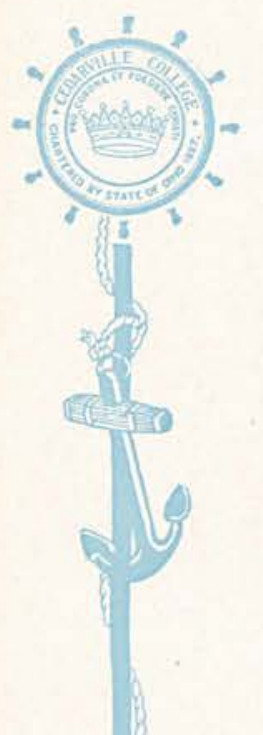
half lives.

Wilma-"Marriage? Pooh! I'd like to see a man get me into that situation." Mr. Curry - "I am positive you would, darling."

According to Walter Boyer one-half of the wives do not know how the other

“Athletes may come, athletes may go;

And fade as in a dream.

The horsefly is the best of all;

He's always on the team."

Prof. Kuehrmann-"What is a flame test?"

Eddie Irons-"Ask her to go out some evening on a trolley."

Coach Borst-“'“'Do you think we'll win the game, today?"

Team-"We may win and we may lose."

Coach Borst- "Boys, you sure are overconfident."

Bob-"You certainly have lots of cheek."

Louise-"Well, make use of it, baby."

Prof. Steele- “' 'Uneasy rests the head-' finish the sentence."

Freshman from rear-“"That hasn't received a haircut yet."

Thompson- "Where were you last night, Army?"

Armstrong-"Out riding with the boys."

Thompson-"Army, when did the boys start wearing hairpins?"

\section{WE PROPHESY THAT}

Foster will say something some day.

Frank Graham will become a farmer.

Hinton will lose interest in High School next year.

If Rutan isn't married, he soon will be.

Chillicothe street will lose its attraction for Smith. Yeh? 


\section{The Cedrus}

\section{CEDARVILLE COLLEGE}

\section{Is Forging to the Front}

\section{GET A COLLEGE TRAINING}

The times demand it.

The results justify it.

COME TO CEDARVIILE COLIEGE

The location is healthful and beautiful.

The opportunities are fine and inspiring.

The courses are complete and modern.

The influences are safe and healthful.

The expenses are lower than at many other places.

The students are possessed of high ideals and practice them.

The faculty is experienced and thoroughly trained. Football, Basketball, Baseball and Tennis

\section{Physical-Education and Gymnasties}

The College is recognized by the Department of Public Education of the State of Ohio, and by the leading universities.

All modern courses. Teachers' courses.

In Cedarville College you can get preparation for any pursuit in life.

A large Freshman class is to enroll in September. The prospects for a record-breaking attendance are splendid. Largest attendance in history of the College last year.

Thirty-sixth Year Opens September 11, 1929

For catalog and further particulars, address

W. R. MeCheSNEY, Ph. D., D. D., President Cedarville, Ohio 


\section{The Cedrus}
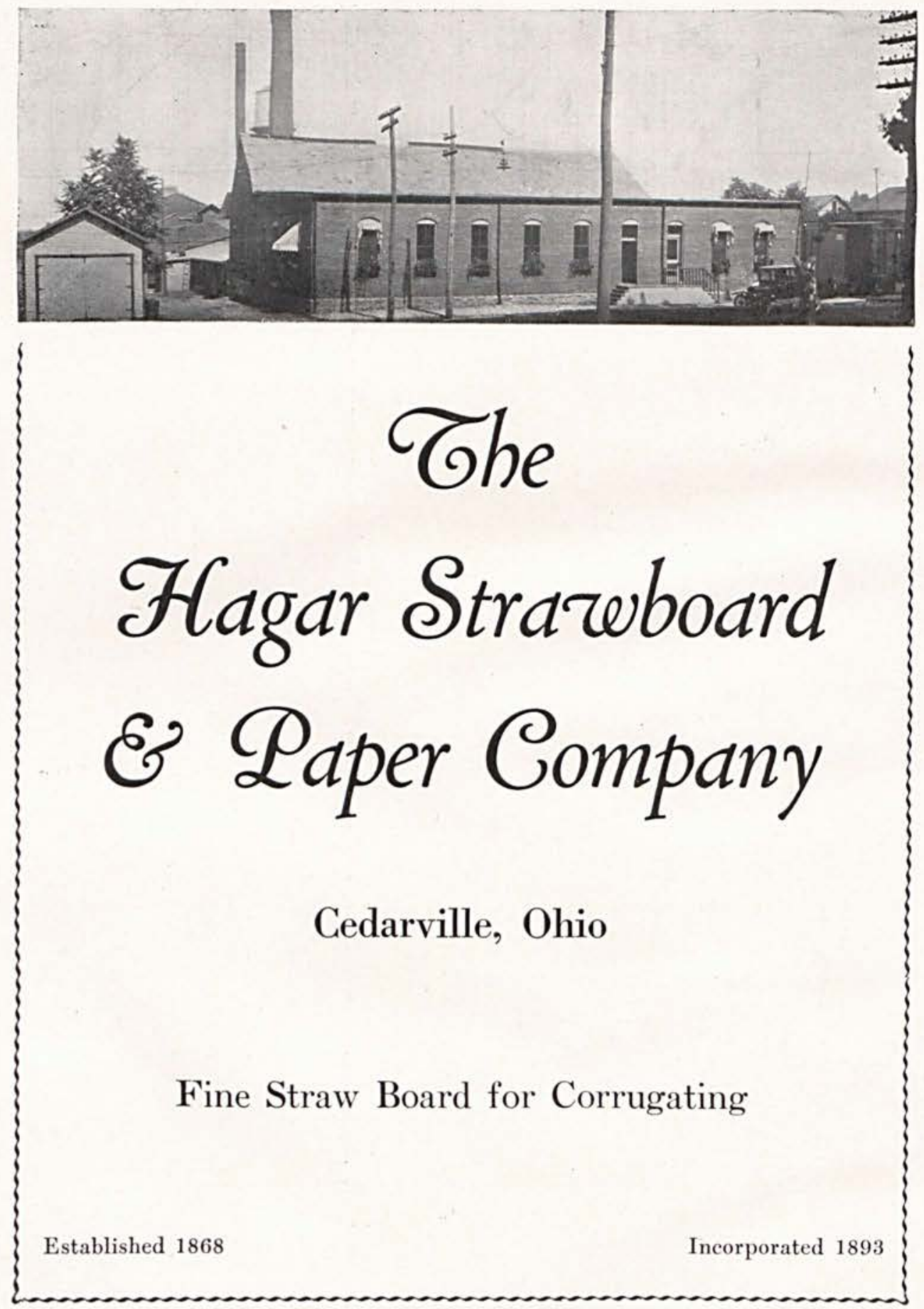

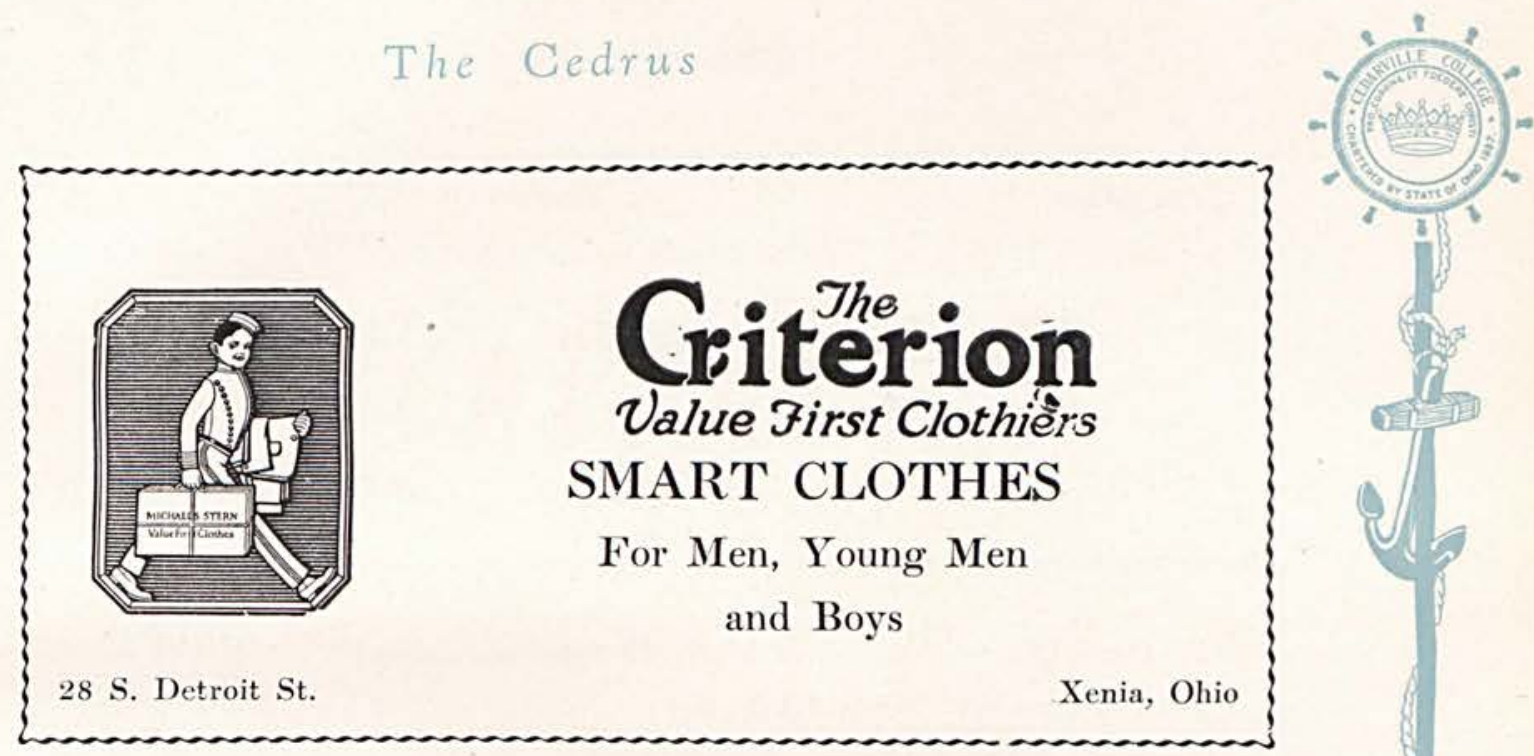

Sarah Margaret-Do you believe in petting parties?

Brenton-That depends on who the party is.

$\mathrm{Oh}$, the girls are like the trolleys,

You can always get another;

And if you wait a little late

They travel faster, brother.

"Jake"-If you had five dollars in your pocket what would you do?

"Happy"-I'd think I had somebody else's pants on.

SEE THE

\section{OUTSTANDING CHEVROLET}

OF CHEVROLET HISTORY

at

A SIX IN THE PRICE RANGE OF THE FOUR

LANG CHEVROLET CO.

XENIA, OHIO 


\section{The Cedrus}

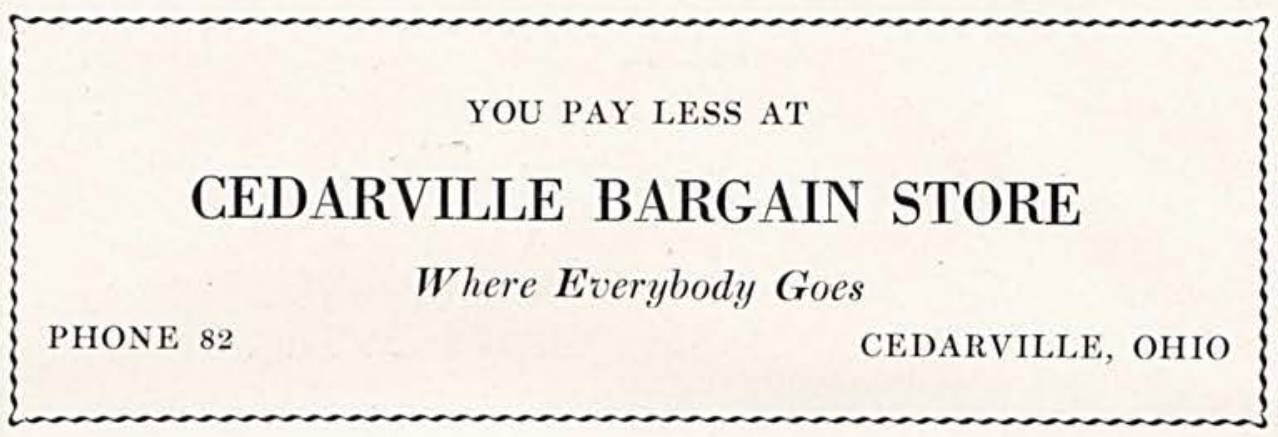

Frazier-Did you hear about McNeel's Jamestown date?

Dr. Jurkat-No. When did he go?

Frazier-But he didn't go. Rowsey went in his place.

Dr. Jurkat-Oh, McNeel had presence of mind and absence of body.

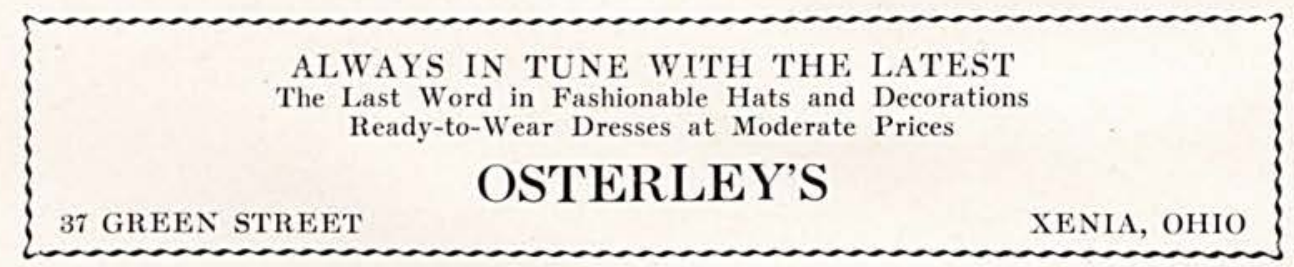

"Smitty" says that the love game is one game that is never called on account of darkness.

Senior-Hey, Mack, what time is it?

Freshman-How'd you know my name was Mack?

Senior-Oh, I just guessed it.

Freshman-Well, guess the time then.

\section{THE EXCHANGE BANK}

\section{CEDARVILLE, OHIO}

We solicit your account-four per cent on savings 


\section{The Cedrus}

DRY CLEANING

"We Care for Those Who Care"

PRESSING

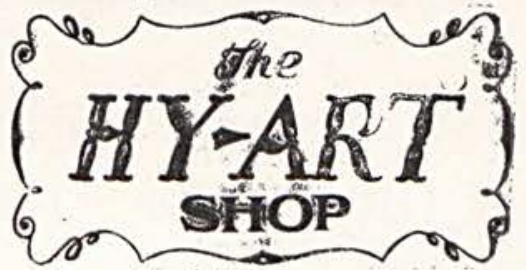

STEELE BLDG., XENIA, OHIO

Phone "13" TAILORING

"Unlucky for Dirt"

She-Why do you keep looking at that girl's evening dress?

$\mathrm{He}-\mathrm{I}$ wanted to see what it was all about.

\section{W. L. Clemans}

Life, Health, Accident, Fire and Tornado INSURANCE

CEDARVILLE,

OHIO

One of the Normal girls thinks that a courtroom is a parlor with the lights turned off and mother and dad gone to the movies.

"Always the Best at Lowest Possible Prices" ROBER'T BIRD and SONS CO.

"Buy at Bird's and Buy the Best" 


\title{
MCCAMPBELL'S EXCHANGE
}

\author{
COAL-GRAIN-FEED \\ HIGH GRADE GASOLINE
}

Kerosene, Oil and Greases

Terms: Cash Only

CEDARVILLE

$\mathrm{OHIO}$

"Too bad about Charlie, isn't it?"

"What's that? The old crocodile in trouble?"

"Naw, he was disappointed in love."

"Well, who isn't?"

\section{A. WAGNER, O. D. \\ Specializing in}

FINE WATCHES and DIAMONDS-COMFORTABLE EYEGLASSES $18 \mathrm{~S}$. DETROIT ST.

PHONE 41

XENIA, OHIO

"I love you, dearie."

"You don't mean it!"

"Gee, you're a regular mind reader." dental.

We know a Chinaman who got into a tong war because it was purely Occi-

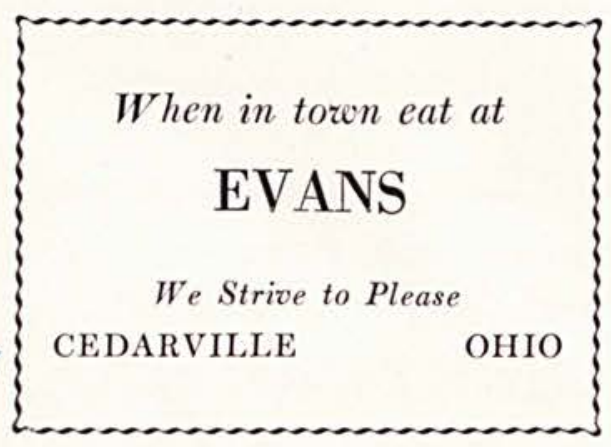

Experience, Equipment and Education

Make Your Work Well Done WE HAVE IT

WOLFORD GARAGE

Storage, Oils and Greases

Fage One Hundred Eighteen. 


\section{The Cedrus}

\section{E. Masters}

\section{Grocery and Meat Market}

Phone 2-44

CEDARVILLE, OHIO

Beam- "Boccaccio must have been inspired when he wrote those stories."

Lemon- "Inspired, nothin'; he must have been excited."

Lenora- "What kind of a car have you?"

Jimmy- "Oh, a runabout. You know, runabout a mile, then stop."

\section{GALLOWAY \& CHERRY}

Furniture, Floor Coverings, Draperies, Ranges, Etc.

Wendell- "Coach Borst got some new waterproof pants for the football men." Mary - "Oh, the big babies!"

Alberta- "I don't like your moustache."

Dallas- "Well, you don't have to use it for a toothbrush."

\section{THE CEDARVILLE HERALD}

Commercial - C Catalog

\section{JOB PRINTING}

LET US GIVE YOU AN ESTIMATE ON YOUR PRINTING 


\section{The Cedrus}

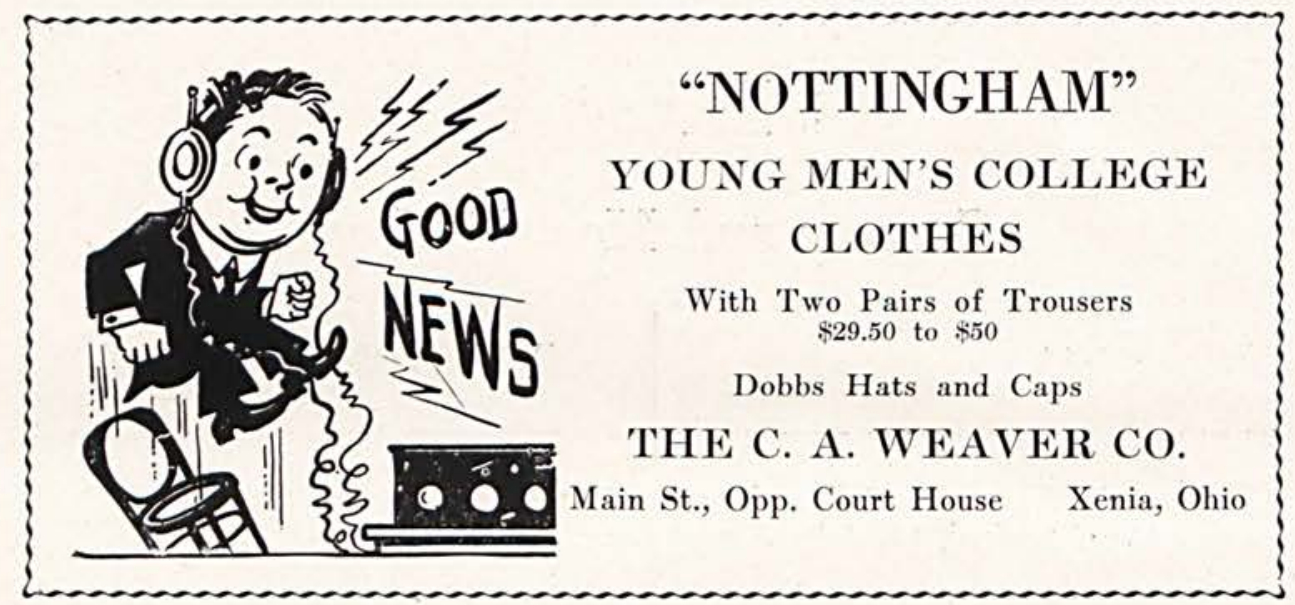

Coach Borst- "We have too many Scotch athletes on the baseball team."

Paul Tanner-“"Who are they?"

Coach Borst-“'The boys who won't loosen up their muscles."

When HUNGRY Come to "Ye Ole CEDAR INN" Tea Room When "TIRED" Try Our REST ROOM

Speaker to Y. W. C. A.- "Don't you want to be the kind of girls that people look up to?"

Y. W. C. A.- "Naw, we wanna be the kind that people look around at."

\section{Patronize-}

\section{C. NAGLEY'S}

I. G. A. FOOD MARKE'T

Phone 104

Cedarville, Ohio 


\section{Theeler Studio}

\section{Photographer for the CEDRUS}

Phone 349-W

$11 \frac{1}{2}-13 \frac{1}{2}$ Green Street

XENIA, OHIO

Irons-“Jean is a man hater."

Allen- "Howzat?"

Irons-Hates to be without:'em."

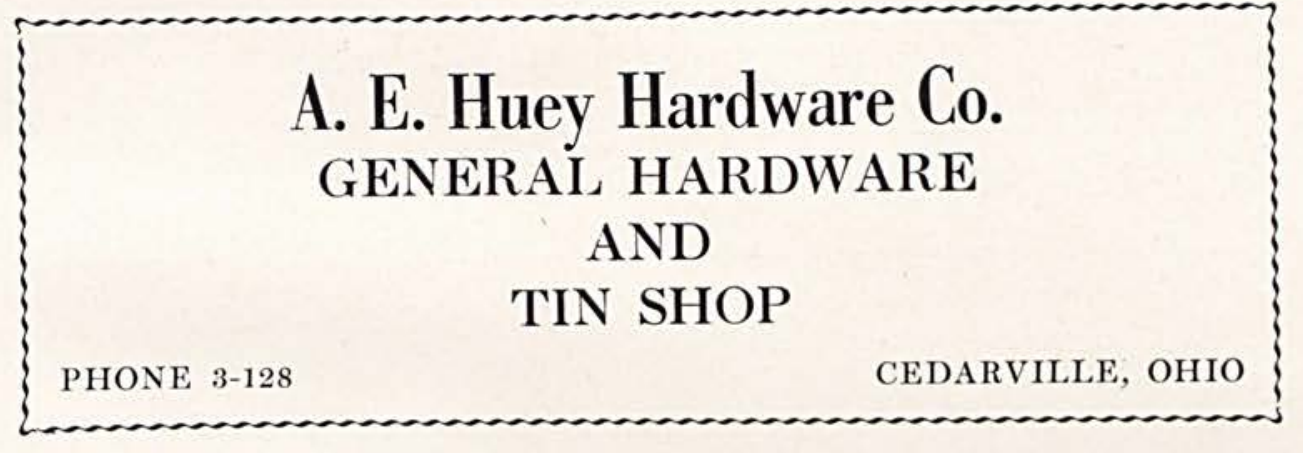

Alfred-"Wasn't that Cleo driving past in that chariot?"

Leo- "Oh, no, it couldn't possibly have Ben Hur."

Don't be too hard on the co-eds; they're hard enough already.

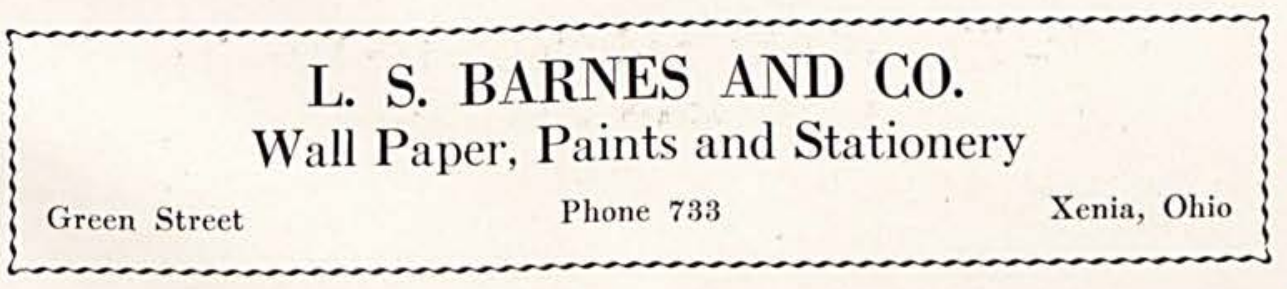




\section{The Cedrus}

\section{The Cedarville Bakery and Confectionery \\ P. M. GILliLAN, Prop.}

Fine Baked Goods and Confections

Exclusive Agents for Battle Creek Food Company's Health Foods Special prices given to Churches, Lodges and those who buy in quantities

"Cleanliness and Quality"-Our Motto

Y. M.- "May I have the next dance?"

Y. W.- "If you press me."

Y. M.- "Wait until we start dancing."

\section{THOMAS AND CROUSE}

\section{Grocery and Meat Market}

She- "I don't love you."

$\mathrm{He}-$ "But when I come into the room your face always lights up."

She- "Oh, that's just a flash in the pan."

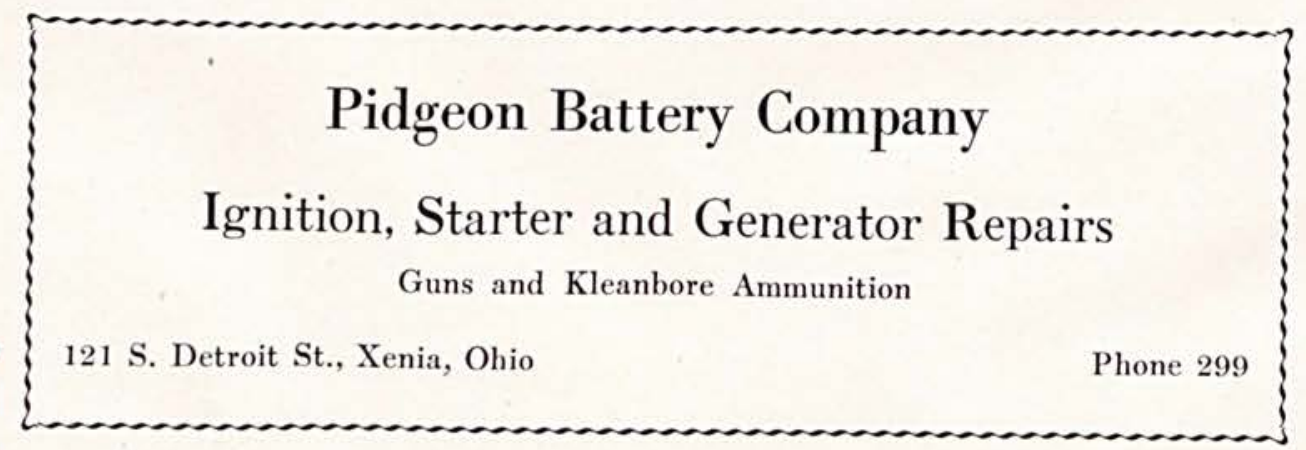


The Cedrus

\section{STANDARD ICE CREAM}

Goodness! How You'll Like It

By far the most popular Ice Cream in Cedarville for the past 15 years. There must be reasons for this continued popularity.

Special and Fancy Creams and Ices for all occasions

\section{RICHARD'S DRUG STORE}

"Popular With the Students"

MAKE YOURSELF AT HOME AT "DOC'S" 


\section{The Cedrus}

\section{CEDARVILLE LUMBER CO.}

EVERYTHING IN

Lumber, Mill Work, Building Material, Fence and Posts, Wool, International Farm Machinery, Trucks, Tractors and Repairs

PHONE 33

Barber-“Is there any particular way you want your hair cut?"

Freshman-"Yeh. Off."

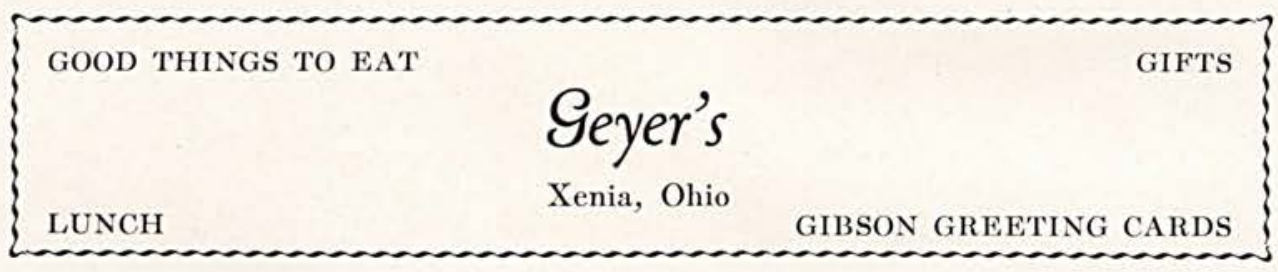

"So you've landed a man at last?"

"Yes, but you should have seen the ones that got away."

Kenny- "Let me kiss you under the mistletoe."

Madge- "Say, I wouldn't let you kiss me under an anesthetic."

When you need Tires take advantage of our Free Road Service

Phone 533

Dayton Tires, Gould Dreadnaught Batteries, Quaker State Oil

Xenia Auto Necessity Company

T. R. MeCLELLAND

R. J. MeCLELLAND

31 South Detroit Street

Xenia, Ohio

Page One Hundred Twenty-four 


\section{The Cedrus}

DRY CLEANING

DYEING

CARPET CLEANING

KIBLER CLOTHES

"The Most for Your Money"

VALE'T PRESS SHOP

33 South Detroit Street

Xenia, Ohio

A Him to a Her Flea- "Marry me or I'll go to the dogs."

Rachel-"What's the difference between a girl and a horse?"

Don- "I don't know."

Rachel-"I'll bet you have some great dates."

MEN'S AND BOYS' WEARING APPAREL

High in Quality-Reasonable in Price

HOME CLOTHING COMPANY

Trade at Home

G. H. HARTMAN, Prop.

Wilma- "I just can't imagine my twenty-first birthday.",

Mary Ruth- "I know time dims one's memory terribly."

Irene-“Oh, those awful week nites!!"

Roy- "But they're wonderful nites to be weak."
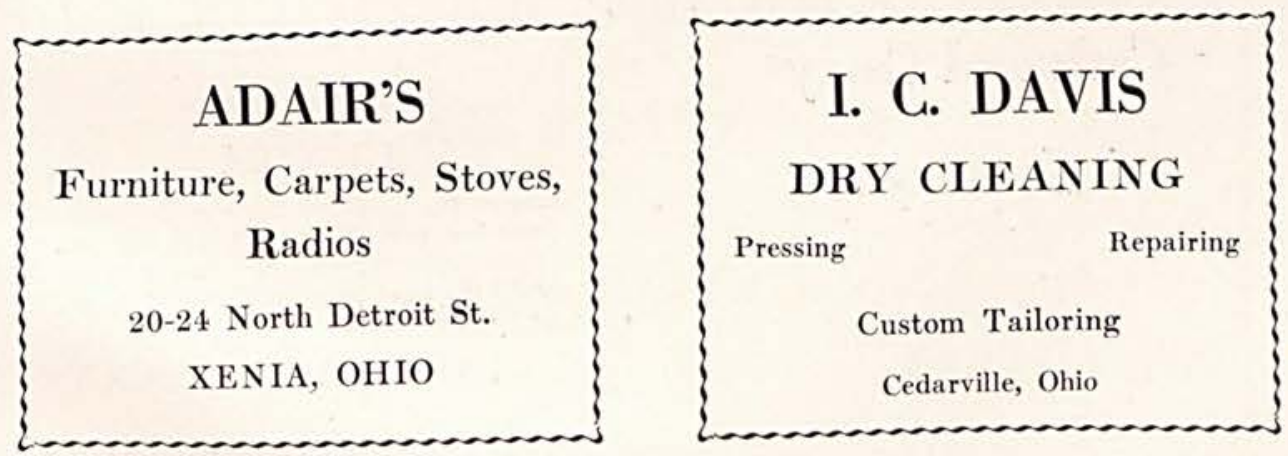


\section{The Cedrus}

\section{COMPLIMENTS OF \\ The Miami Valley Co-operative Milk Producers Association}

an hour.

Cedarville has the world's speediest co-ed. She makes at least forty males

Colvin-"Have you heard the new companionate marriage song?"

North-"No, what is it?"

Colvin- "Love, Honor and No Baby."

Frazier- "Why do you say that you don't like those old-fashioned girls?"

McNeel- "Too much bustle to get any place."
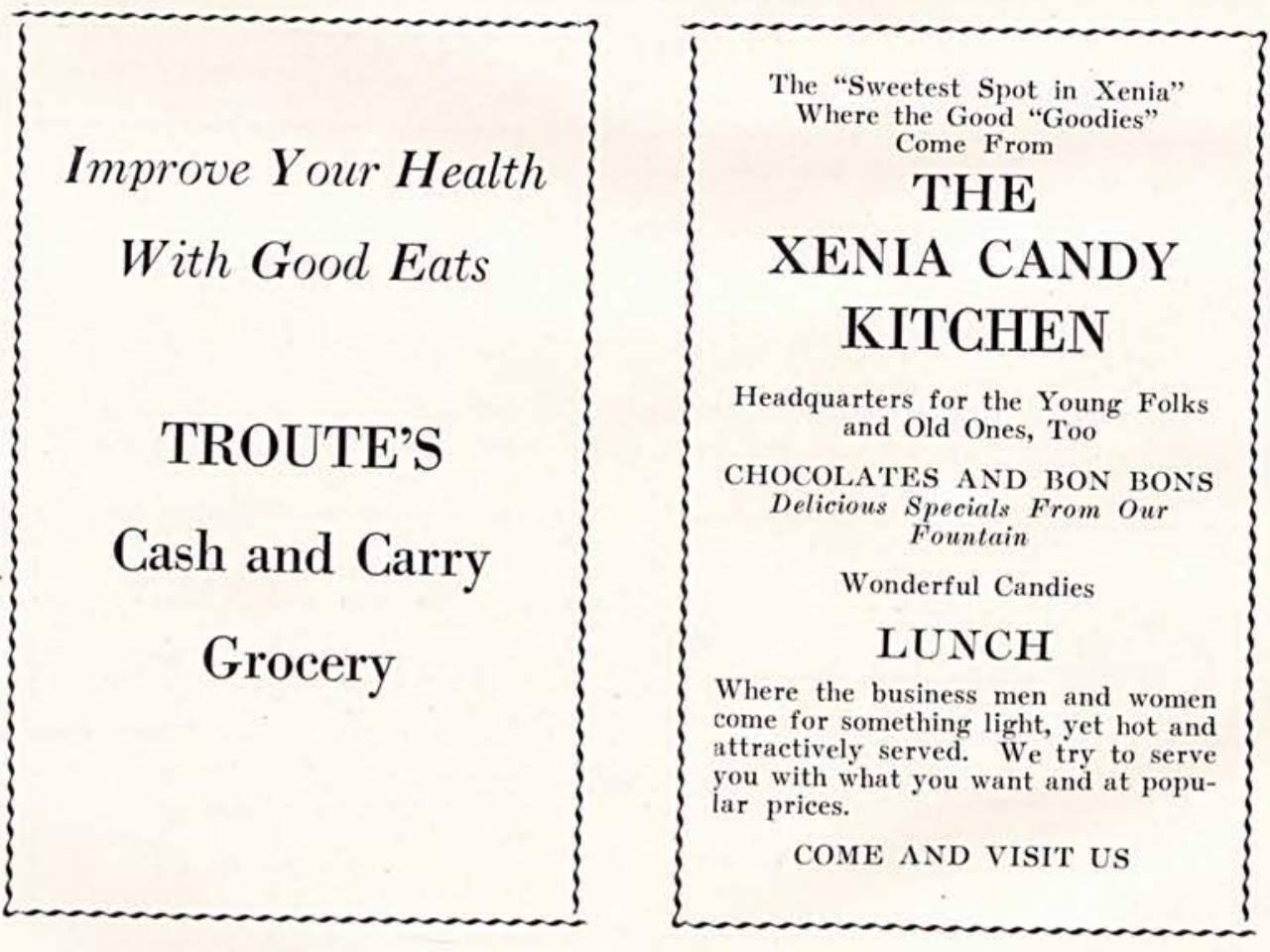

Page One Hundred Twenty-six 


\title{
The Cedrus
}

\section{GIB McCOY'S BARBER SHOP}

It pays to look your best

YOUR PATRONAGE APPRECIATED

Some college boys waste a lot of time trying to make their work lighter; others do the same thing trying to make their lighters work.

The co-eds' clothes seem to be going to their heads.

Parting advice: Put a little water on the comb.

Height of laziness - College boy who is too lazy to write home for money.

\section{McCURRAN BROS.}

\author{
General Contractors
}

PUBLIC BUILDINGS

FINE RESIDENCES

Our Specialty

STEELE BLDG.

XENIA, OHIO 


\section{The Cedrus}

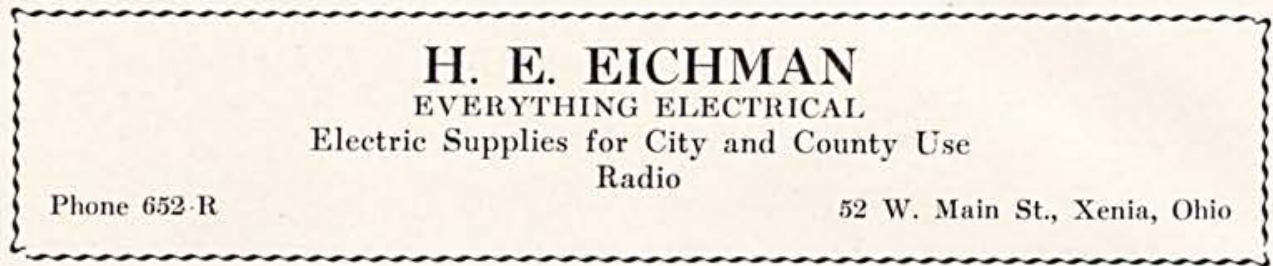

A Cedarville co-ed thinks that Salome would have done a much better job if she had turned John's head instead of cutting it off.

Pickering- "Why does Keach keep walking up and down past the girls' rooming houses?"

Dean- "He's window shopping."

QUICK LUNCH-SOFT DRINKS-BILLIARDS

SMOKERS' SUPPLIES

HARPER'S BILLIARD HALL

Jasper- "Dearest, I love you terribly."

Betty- "You certainly do."

Femme- "They say that you have been disappointed in love."

Homme- "Not at all, love is all right."

\section{ANDERSON'S FLOWER SHOP}

\section{"Say It With Flowers" \\ FANCY FLOWERS FOR ALL OCCASIONS}

Flowers Telegraphed Everywhere 

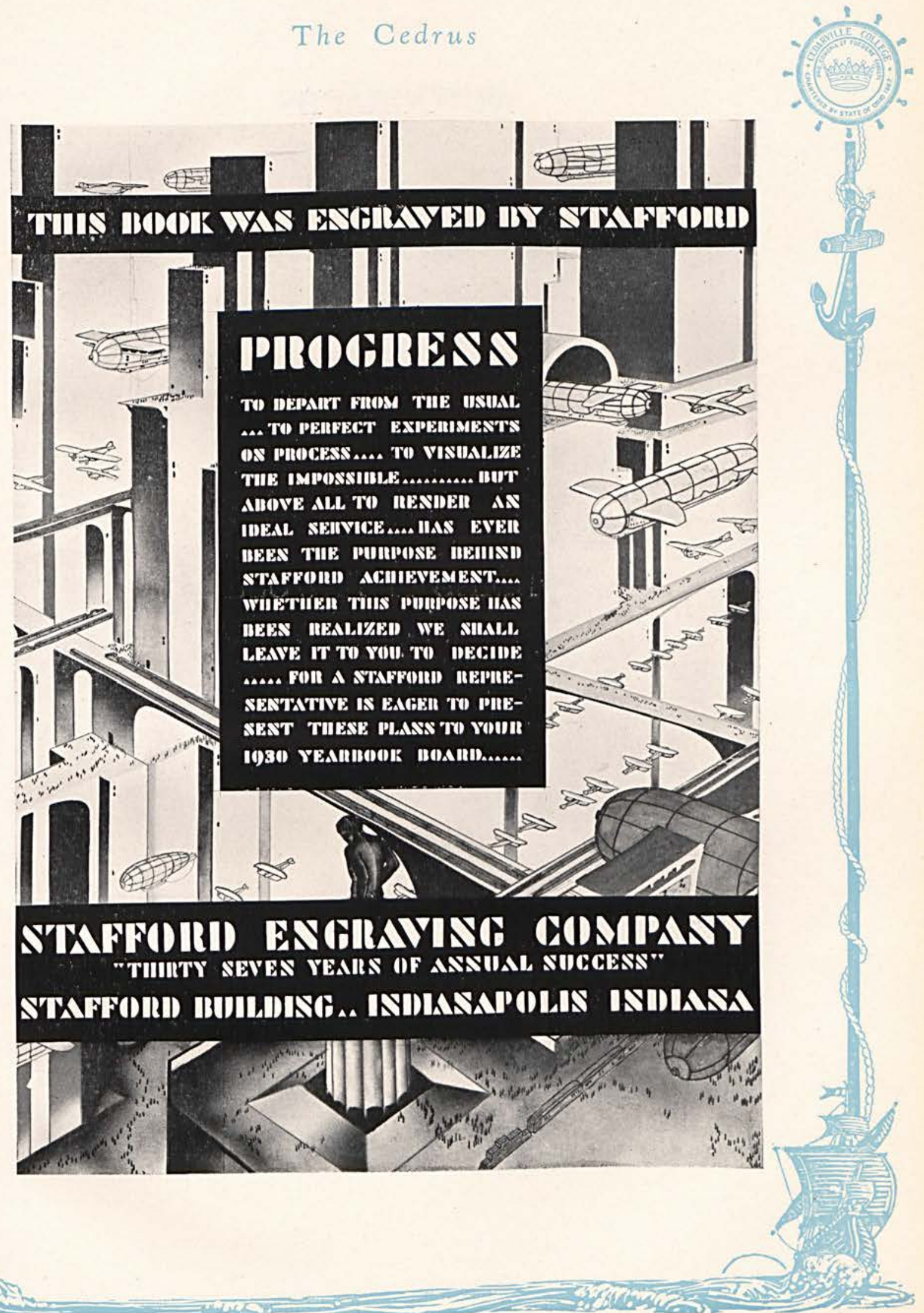


\section{The Cedrus}

\section{AUTOGRAPHS}


The Cedrus

AUTOGRAPHS

(बतits
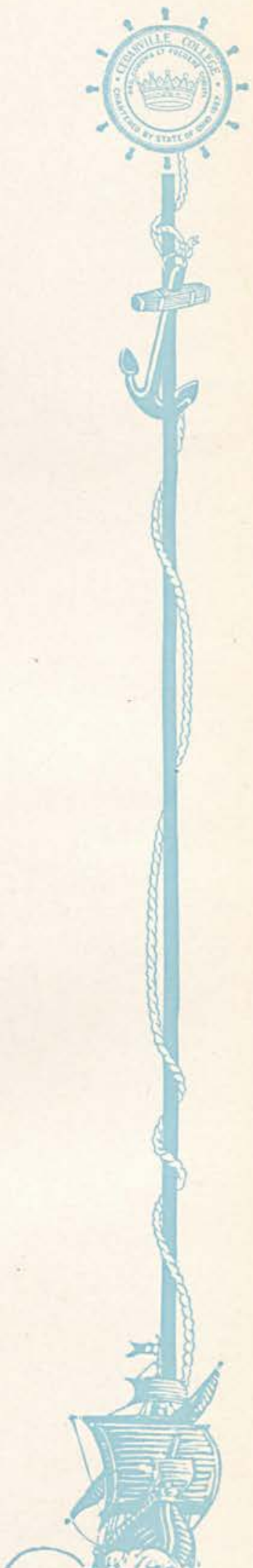
The moving finger writes, having writ, Moves on; nor all your piety nor wit Shall lure it back to cancel half a line, Nor all your tears wash out a word of it. 



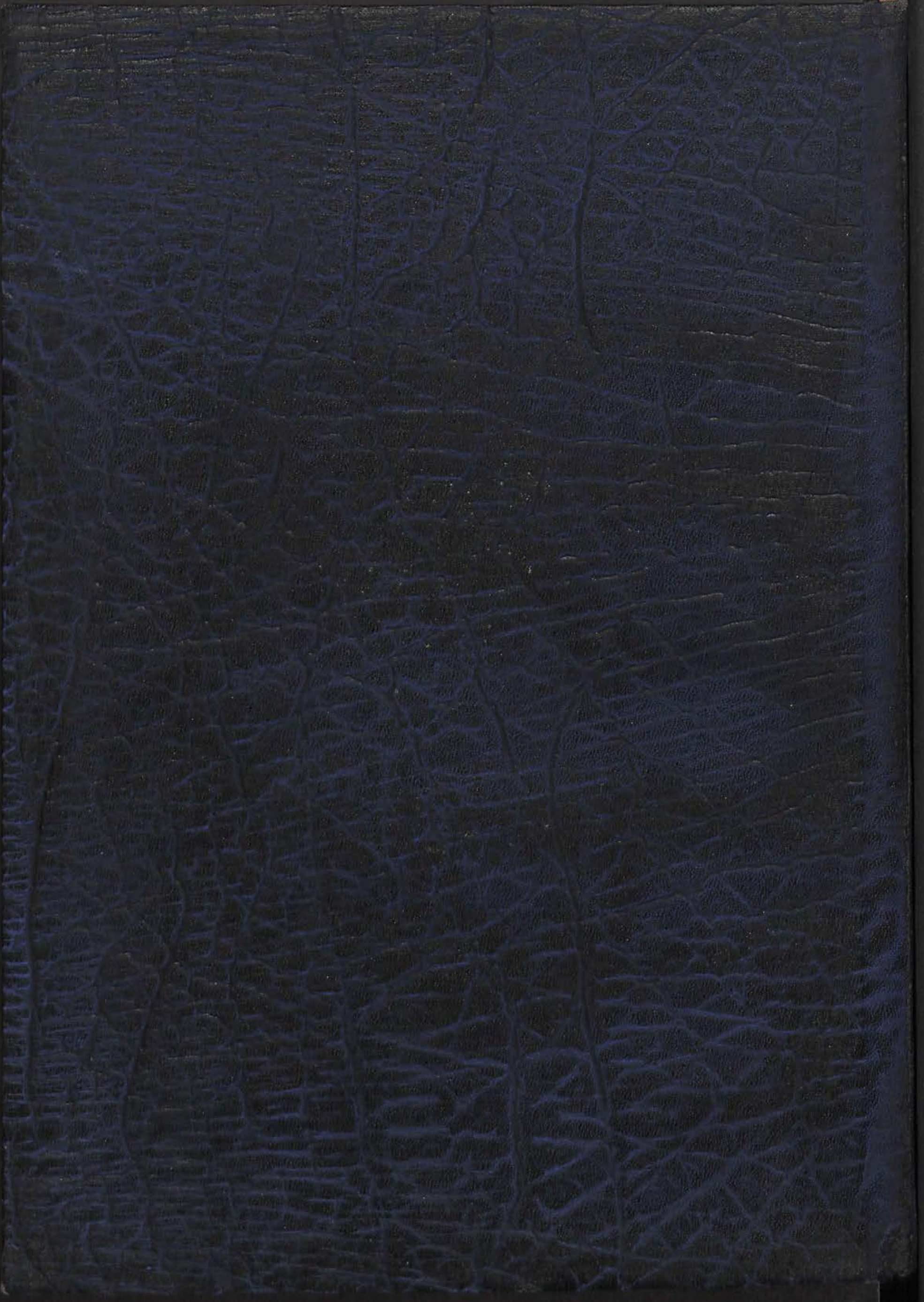

